\author{
UNIVERSIDADE DE SÃO PAULO \\ FACULDADE DE FILOSOFIA, LETRAS E CIÊNCIAS HUMANAS \\ DEPARTAMENTO DE LETRAS CLÁSSICAS E VERNÁCULAS \\ PROGRAMA DE PÓS-GRADUAÇÃO EM FILOLOGIA E LÍNGUA PORTUGUESA
}

KATIUSCIA CRISTINA SANTANA

AS PERSONAGENS-TIPO NA ORALIDADE REPRESENTADA:

UM ESTUDO DA PEÇA O JUIZ DE PAZ DA ROÇA, DE MARTINS PENA

Versão Corrigida

SÃO PAULO

2013 


$$
\text { UNIVERSIDADE DE SÃO PAULO }
$$

FACULDADE DE FILOSOFIA, LETRAS E CIÊNCIAS HUMANAS

\title{
AS PERSONAGENS-TIPO NA ORALIDADE REPRESENTADA: \\ UM ESTUDO DA PEÇA O JUIZ DE PAZ DA ROÇA, DE MARTINS PENA
}

\author{
KATIUSCIA CRISTINA SANTANA
}

Dissertação de Mestrado apresentada ao

Programa de Pós-Graduação em Filologia e Língua Portuguesa do Departamento de Letras Clássicas e Vernáculas da Faculdade de Filosofia, Letras e Ciências Humanas da Universidade de São Paulo, para obtenção do título de Mestre em Letras.

Orientador: Prof.Dr. Hudinilson Urbano

Versão Corrigida

De acordo

Prof.Dr.Hudinilson Urbano

São Paulo 
SANTANA, Katiuscia Cristina. As personagens-tipo na oralidade representada: um estudo da peça O Juiz de Paz da roça, de Martins Pena. São Paulo: Universidade de São Paulo, 2013. Dissertação (mestrado). Faculdade de Filosofia, Letras e Ciências Humanas. Universidade de São Paulo, São Paulo, 2013.

Dissertação de Mestrado apresentada ao Programa de Pós-Graduação em Filologia e Língua Portuguesa do Departamento de Letras Clássicas e Vernáculas da Faculdade de Filosofia, Letras e Ciências Humanas da Universidade de São Paulo, para obtenção do título de Mestre em Letras.

Aprovada em:

BANCA EXAMINADORA

Prof. Dr. Hudinilson Urbano - Orientador Universidade de São Paulo

Prof.Dr. Luiz Antônio da Silva

Universidade de São Paulo

Prof.Dr. Gilmar Bueno Santos

Universidade Federal de Minas Gerais 


\section{AGRADECIMENTOS}

À minha amada família: minha mãe Márcia, meu pai Dimas e meu irmão Douglas, por todo o apoio, carinho e toda a educação a mim concedida.

Às minhas avós, in memoriam, Nelly e Benedita, que, infelizmente não puderam estar ao meu lado em mais uma conquista.

Ao Prof. Dr. Hudinilson Urbano que me orientou com paciência, dedicação e por ter me dado a oportunidade de desenvolver o projeto de pesquisa. Minha referência de pesquisador.

À Prof ${ }^{a}$. Drª . Marli Quadros Leite, pela atenção demonstrada no processo de seleção para a Pós.

Aos professores Dr. Luiz Antônio da Silva e Dr. Marcelo Módolo, pelas críticas e sugestões feitas ao trabalho na banca de qualificação.

Ao Prof.Dr. Gilmar Bueno Santos, pelo apoio e pela atenção durante o Congresso da ABRALIN em Natal/RN.

Às queridas e inspiradoras professoras Márcia de Azevedo Arouca e Mônica Arouca, por toda a atenção e sugestões.

À Prof ${ }^{-}$Dr ${ }^{a}$ Tokiko Ishihara, que me orientou na Iniciação Científica durante a graduação.

À querida professora Maria Regina Reis de Souza, que me apoiou durante o Ensino Médio e fez com que eu acreditasse que a USP era um sonho possível.

À querida vizinha e amiga Cássia, por todo o carinho manifestado sempre.

Às queridas amigas Sandra Gomes, Avonandrianina Razafindrazaka, Regina K. Souza e Mariana Reis Souza por todo o carinho sempre e durante o processo de realização desta dissertação. 
Ao Pedro Luiz Souza e à Patrícia Ussier, pelo apoio e compreensão em momentos de ausência.

À Fabiane Alves, pela atenção e pelo suporte tecnológico.

Ao Raoni Caldas, pela atenção e por disponibilizar a tradução de Oesterreicher antes de sua publicação

A todos os meus amigos e alunos, por terem compreendido a minha ausência durante o processo de realização desta dissertação.

A todos que contribuíram, direta e indiretamente, para a realização desta pesquisa. 
SANTANA, Katiuscia Cristina. As personagens-tipo na oralidade representada: um estudo da peça O Juiz de Paz da roça, de Martins Pena. São Paulo: Universidade de São Paulo, 2013. Dissertação (mestrado). Faculdade de Filosofia, Letras e Ciências Humanas. Universidade de São Paulo, São Paulo, 2013.

\section{RESUMO}

Com foco na comédia $O$ Juiz de Paz da roça, de Martins Pena, escrita durante o período romântico da Literatura, objetivamos mostrar a relação entre a representação da linguagem falada e a caracterização das personagens-tipo da peça. Personagens-tipo são aquelas que representam uma sociedade ou um grupo social normalmente presentes na literatura de ficção em geral. A fundamentação teórica constitui-se da Análise da Conversação, da Pragmática e da Sociolinguística Interacional. Partimos da hipótese de que, assim como a ação de modo geral das personagens na peça teatral, a linguagem falada exerce fundamental importância para a caracterização dessas personagens, tão comuns nas comédias de costumes e que teve em Martins Pena o seu precursor no Brasil. A construção de tipos sociais de personagens é possível graças à atenção que o autor atribui à representação da modalidade falada da época somada ao ambiente, em que vários tipos sociais interagem. Assim como as escolhas lexicais, as formas de tratamento entre outros elementos linguísticos caracterizam personagens-tipo, levando em consideração a significação das palavras e as várias relações entre locutores e interlocutores, tais como gênero, idade, grau de formalidade, respeito e intimidade no contexto da obra. Dessa forma, nesta dissertação, está presente uma análise dos papéis das personagens da peça por meio de um estudo de elementos não verbais e verbais, como o léxico, as formas de tratamento e aspectos fonológicos para revelar uma tipificação e hierarquização das personagens na peça escolhida para esse trabalho.

Palavras-chave: Martins Pena; Romantismo; teatro; personagens-tipo; representação da oralidade. 
SANTANA, Katiuscia Cristina. Stock characters in represented orality: a study of the play O Juiz de Paz da roça by Martins Pena. São Paulo: Universidade de São Paulo, 2013. Dissertation (Master's degree). Faculdade de Filosofia, Letras e Ciências Humanas. Universidade de São Paulo, São Paulo, 2013.

\section{ABSTRACT}

By focusing on the comedy O Juiz de Paz da roça, by Martins Pena, from the Romantic period of the Literature, we aim to present the relation between representation of the spoken language and the characterization of stock characters. Stock characters represent a society or a social group, which are presented in literary fiction in general. Based on the theoretical framework of Conversation Analysis, Pragmatics and Interactional Sociolinguistics, we start from the hypothesis that, just like actions in a play, spoken language plays a crucial role for the characterization of these characters, which are very common in the comedy of manners, which had Martins Pena as its precursor in Brazil. The construction of social types is possible because of the author's work of representing the spoken language at that specific time along with an environment where several stock characters interact. As well as lexical choices, forms of address and other linguistics elements feature the stock characters, taking into consideration the significance of the words and various relationships between the locutors and interlocutors, such as gender, age, degree of formality, politeness and intimacy in the context of the author's work. Thus, this dissertation presents an analysis of each character's role in the play, by analyzing non-verbal and verbal elements such as lexical forms, forms of address and phonological aspects in order to reveal how the typification and the hierarchy of the characters is constructed in the given play.

Key-words: Martins Pena; Romantic period; theater; stock characters; orality representation. 
"[...] os verdadeiros dramaturgos, os nomes que realmente contam, mostramse sempre capazes de elaborar um estilo pessoal e artístico a partir das sugestões oferecidas pela palavra falada, aproveitando não somente a gíria, as incorreções saborosas da linguagem popular, mas também a sua vitalidade quase física, a sua vivacidade, a sua irreverência e a sua acidez, as suas metáforas cheias de invenção poética".

\section{Décio de Almeida Prado}

"Em termos de diálogo, poderíamos afirmar que a reprodução dos dialetos sociais e dos níveis de fala ocorre, geralmente, com mais fidelidade, na prosa de costumes, quando a linguagem da personagem é um dado a mais para o autor criar o painel social que nos quer mostrar".

\section{Dino Preti}




\section{SUMÁRIO}

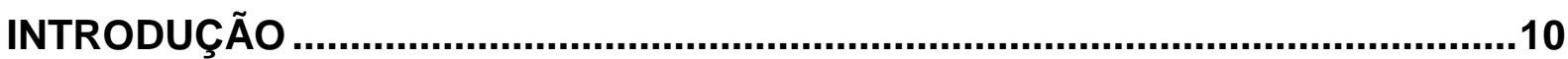

CAPÍTULO 1: MARTINS PENA E O CONTEXTO TEATRAL BRASILEIRO NO

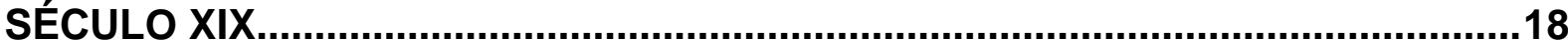

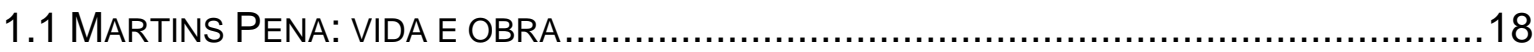

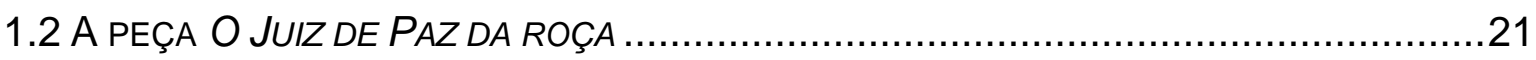

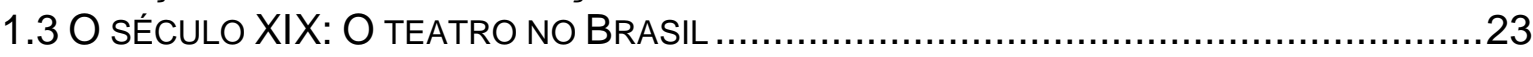

CAPÍTULO 2: AS CARACTERÍSTICAS DO TEXTO TEATRAL .............................28

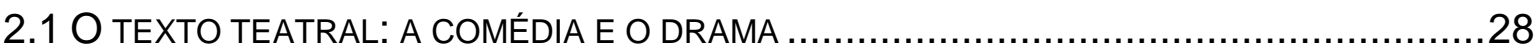

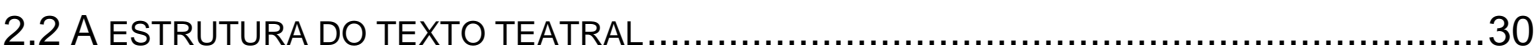

2.3 DIDASCÁLIAS: USOS E FUNÇÕES NO TEXTO TEATRAL ..............................................

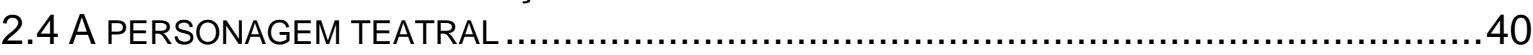

CAPÍTULO 3: A ORALIDADE E AS MÚLTIPLAS FALAS NO TEXTO TEATRAL .43

3.1 O CONCEITO DE ORALIDADE E DE ESCRITURALIDADE ...........................................43

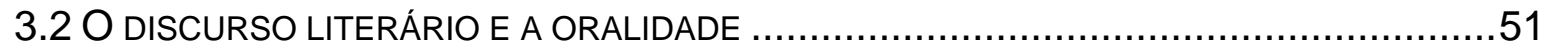

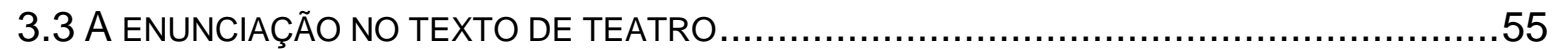

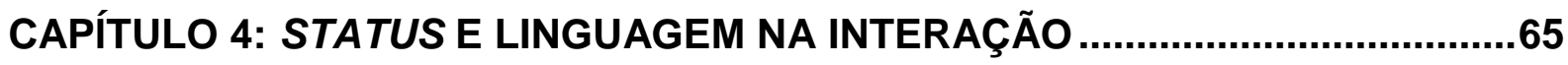

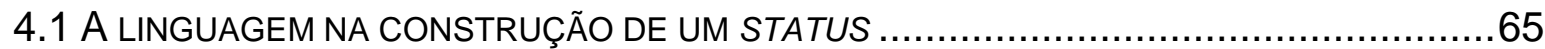

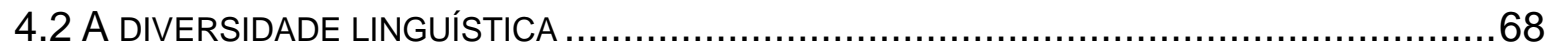

4.3 O LÉXICO NA CONSTRUÇÃO DE UM STATUS.................................................

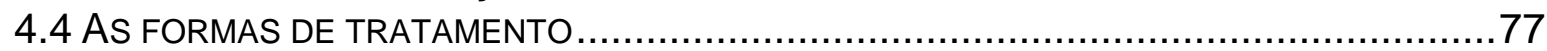

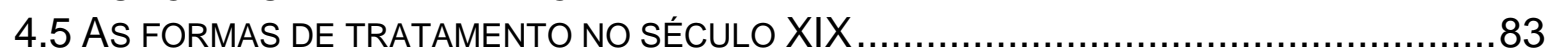

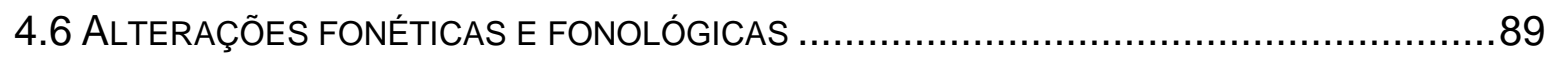

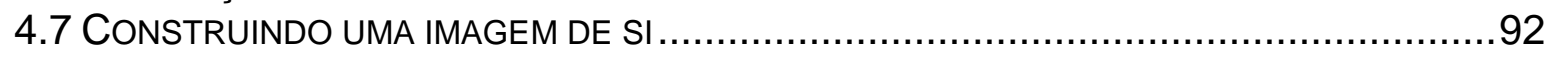

CAPÍTULO 5: ANÁLISE DA PEÇA O JUIZ DE PAZ DA ROÇA...........................96

5.1 AS ESCOLHAS LEXICAIS EM O JUIZ DE PAZ DA ROÇA ........................................99

5.1.1) Escolhas lexicais caracterizadoras da "fachada social" das personagens

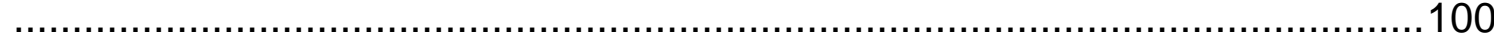

5.1.2) Escolhas lexicais caracterizadoras do espaço físico da ação.................109

5.1.3) Escolhas lexicais caracterizadoras do registro formal ou informal.........112

5.1.4) Escolhas lexicais caracterizadoras de costumes de brasileiros do século

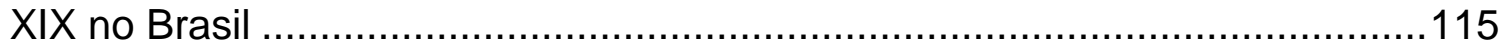

5.2 AS FORMAS DE TRATAMENTO EM O JUIZ DE PAZ DA ROÇA ...............................129

5.2.1) A representação das mulheres ........................................................129

5.2.2) A representação dos escravos …………......................................147

5.2.3) A representação do vadio José da Fonseca .......................................152

5.2.4) A representação do Juiz de Paz ..................................................156

5.2.5 ) A representação do Escrivão .......................................................166

5.3 ASPECTOS FONOLÓGICOS NA PEÇA O JUIZ DE PAZ DA ROÇA ...............................172

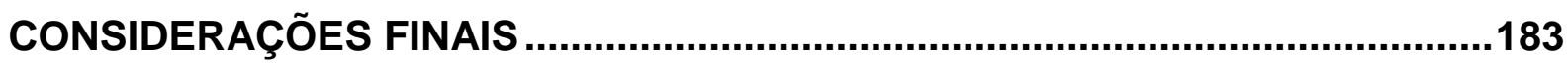

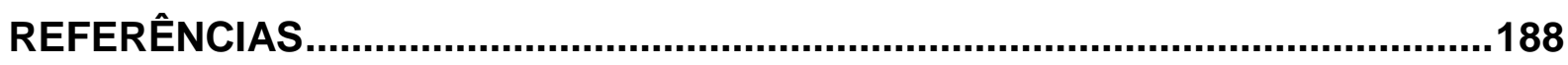

ANEXO 


\section{INTRODUÇÃO}

A literatura pode nos fornecer subsídios para o estudo de manifestações linguísticas em uma comunidade de fala, principalmente em se tratando de épocas anteriores, como o século XIX no Brasil. Trata-se de uma época pouco estudada em termos linguísticos, uma vez que há pouco material linguístico-descritivo disponível para pesquisas. Para se concretizar o estudo de manifestações de linguagem em uma determinada comunidade, um dos modos possíveis é a análise dos diálogos das personagens literárias, diálogos esses que constituem uma espécie de personificação tanto "física" quanto linguística no texto de ficção.

O presente trabalho orienta-se para o estudo da caracterização de personagens-tipo por meio da representação da oralidade na peça $O$ Juiz de Paz da roça, de Martins Pena. Com foco principal nas formas de tratamento, nos aspectos fonológicos e no léxico, busca-se identificar, descrever e analisar as estratégias linguísticas utilizadas pelo escritor para representar a sociedade ou um grupo social.

Luís Carlos Martins Pena é considerado o precursor da dramaturgia brasileira, a da comédia de costumes. Para estudiosos como Bárbara Heliodora (2000), o autor criou um teatro vivo e brasileiro, não só em termos de costumes da época em que sua obra está inserida, mas também em termos de vida dramática e cênica, a tal ponto que Sílvio Romero (1943) julgou a comédia de Martins Pena um retrato histórico da vida do país no século XIX. O comediógrafo destacou-se por criticar as instituições e seus representantes, uma novidade na época.

A escolha do tema se deve ao fato de que a obra de Martins Pena ainda é pouco estudada no Brasil, sobretudo com enfoque na linguagem das personagens, sob o ponto de vista das marcas de oralidade e sua representação na língua falada. 
Em geral, estuda-se a obra teatral de Martins Pena, para o comparar aos demais teatrólogos estrangeiros, ou se estuda a função social de seu teatro na época do Romantismo Brasileiro. Percebe-se, no entanto, que nos estudos da linguagem, há espaço para um trabalho detalhado sobre a mimetização da linguagem falada em seu teatro, considerado, por muitos críticos de teatro, como o "Molière brasileiro". Um repertório tão rico no que diz respeito à elaboração das falas necessita ser divulgado e estudado.

A hipótese desta dissertação é que a linguagem empregada pelas personagens na peça teatral tenta reproduzir a sociedade ou os grupos sociais do Brasil no Rio de Janeiro da época. Justifica-se, portanto, pesquisar a relação da caracterização dos tipos sociais e a linguagem na oralidade representada, visto que se trata de uma peça de teatro e não uma conversação espontânea.

Para a realização desta pesquisa, elegemos como corpus a comédia $O$ Juiz de Paz da roça, primeira peça escrita pelo autor. Consultamos várias edições da obra de Martins Pena, tais como a edição da Organização Simões, organizada por Amália Costa (1951), as edições do Instituto Nacional do Livro e das Edições de Ouro, ambas organizadas por Darcy Damasceno (1956; 1971), a edição Garnier (s.d), a edição da editora Cruz Coutinho (1871) e a edição datilografada da SBAT (Sociedade Brasileira de Autores) vinculada à Biblioteca Nacional, para o estabelecimento de um texto mais fidedigno em termos de linguagem da época. Excluímos os dramas produzidos pelo escritor nesta pesquisa, porque acreditávamos que é na comédia que encontraríamos, marcadamente, as personagens-tipo. O texto integral da peça, baseado na edição datilografada da Biblioteca Nacional, encontra-se no ANEXO desta dissertação e, para a análise, 
selecionamos excertos com o intuito de comprovar as questões levantadas nessa pesquisa.

Tendo em vista a natureza do corpus, o trabalho considera a peça escrita, ou seja, o texto escrito para ser oralizado no palco. Verificamos as estratégias de uso das formas de tratamento e do léxico para o estabelecimento de uma hierarquia social e a construção de um status visando à identificação dos tipos sociais na peça, com base nos parâmetros teóricos da Sociolinguística Interacional, da Análise da Conversação e da Pragmática. De modo geral, explicita-se:

I) O conceito de oralidade no texto literário, em especial no texto teatral;

II) As relações sociais implicadas na utilização das formas tratamentais e lexicais; e

III) Os fatores sociopragmáticos que interferem na escolha lexical e tratamental.

Para discutir o conceito de oralidade no texto literário, destacam-se as pesquisas de Kerbrat-Orecchioni (1984; 1990), Urbano (2000; 2008; 2011) Koch e Oesterreicher (1985) utilizadas aqui para embasamento teórico. No que concerne às formas de tratamento, tomamos como parâmetro os estudos de Cintra (1986) e Kerbrat-Orecchioni (1990), estudos associados à preservação da face de Brown e Levinson (1987) com base em Goffman (1967). Todos esses estudos serão considerados para uma análise de cunho qualitativo, alicerçada em fundamentos sociopragmáticos. Optamos pela investigação qualitativa para descrever e analisar as estratégias linguísticas empregadas pelo escritor na construção das falas das personagens, de acordo com a situação comunicativa.

A análise pragmática é básica para descrever as condições necessárias para a interpretação dos enunciados, integrando os dados contextuais aos dados cotextuais. A adoção dessa perspectiva teórica nos permite conciliar as informações 
das indicações cênicas do autor com as falas das personagens para uma análise mais detalhada dos fenômenos interacionais.

O texto de teatro, planejado para ser dramatizado no palco, sem a mediação de um narrador, caracteriza-se pela predominância do diálogo. No caso desta pesquisa, entende-se que esses diálogos são arquitetados pelo autor para recriar tipos sociais recorrentes no século XIX e para mostrar a realidade por meio da ficção, no Brasil e, sobretudo, no Rio de Janeiro da época.

Abordamos os estudos da Sociolinguística Interacional e da Sociologia para tratarmos das estratégias de representação de tipos sociais na peça escolhida para a análise, visto que as duas abordagens colaboram com o estudo da relação entre língua e sociedade.

Além das perspectivas da Pragmática e da Sociolinguística Interacional, utilizamo-nos dos estudos da Análise da Conversação, que se caracteriza por trabalhar com técnicas de análises empíricas, baseadas em conversações espontâneas. Embora uma conversação inserida num contexto fictício não seja espontânea e real, é possível encontrarmos elementos de uma conversação autêntica em um diálogo elaborado por escritores, uma vez que muitos se preocupam com a verossimilhança de suas personagens.

Para a análise, realizamos um recorte de trechos da comédia $O$ Juiz de Paz da roça, de Martins Pena. Os exemplos estão inseridos em vários quadros, em que sublinhamos os elementos a serem discutidos no trabalho. Foram citadas as linhas conforme estão enumeradas no ANEXO desta dissertação, juntamente com a indicação da página e da cena do ANEXO para a localização precisa dos excertos selecionados da peça. As indicações das páginas, das linhas e das cenas estão destacadas em negrito entre parênteses, para evitar confusão com as indicações 
cênicas do escritor, que são indicadas em itálico. No ANEXO deste trabalho, a reprodução da peça está integral. Para a sua reprodução, consideramos o cotejo das edições de Darcy Damasceno (1956; 1971), Amália Costa (1951) e a versão datilografada pela SBAT. Todas essas edições possuem a característica comum de terem se baseado nos manuscritos originais de Martins Pena. Nas edições consultadas, a grafia da personagem "Juiz de Paz" ora é grafada em maiúsculas ora em minúsculas. Optamos por respeitar as edições, mas adotaremos a grafia em maiúsculas para tratarmos da personagem na análise e a grafia em minúsculas para nos referirmos à profissão de juiz em geral. As linhas do ANEXO estão enumeradas de forma contínua, inclusive o espaço entre as indicações cênicas do autor e as falas das personagens. A cada mudança de cena, decidiu-se mudar a página para a melhor visualização de cada cena.

Em relação ao texto de teatro, o estudo das marcas de oralidade deve levar em consideração as características do texto escrito ou do texto oralizado no palco. A análise comparativa e/ou contrastiva entre o texto escrito e o mesmo dramatizado no palco pode nos revelar estratégias conversacionais próximas da fala natural. $\mathrm{O}$ texto escrito e o dramatizado no palco, juntos, mostram modelos de interação.

Para uma análise da fala da personagem literária, deve-se, também, atentar ao confronto da língua escrita com a oral, bem como às variações provenientes de fatores socioculturais de acordo com o tempo e espaço em que se inserem. Além disso, devemos observar o andamento da interação verbal nas mais diversas situações de comunicação e os efeitos expressivos, provenientes de escolhas estilísticas do escritor e da época literária. Muitas informações a respeito das personagens podem ser dadas quer pelas palavras dos diálogos, quer pelas ações propriamente ditas. 
No que diz respeito ao cômico, o dramaturgo usa com grande frequência recursos contrastantes, tais como as formas de tratamento que indicam formalidade ou informalidade e o uso culto da língua em oposição ao uso popular. É certo que o texto literário pressupõe um processo de elaboração e de planejamento da escrita, diferentemente da dinâmica da língua oral espontânea, desenvolvida de forma imprevista em uma interação.

Em relação ao texto teatral, podemos estabelecer dois eixos de pesquisa: podemos nos restringir à materialidade escrita do texto e reconhecer no próprio texto escrito os elementos comuns encontrados na língua falada ou, então, podemos cotejar e comparar o texto escrito (roteiro ou script) de uma peça teatral com sua respectiva dramatização e encenação no palco, o que não será, entretanto, feito nesta pesquisa.

Esta dissertação está dividida em cinco capítulos. No primeiro capítulo, abordamos a vida de Martins Pena, o século XIX e a peça O Juiz de Paz na roça; no segundo capítulo, a estrutura do texto teatral, a diferença entre a comédia e o drama, as funções das indicações cênicas do autor conhecidas como didascálias e as personagens no texto teatral; no terceiro capítulo, abordamos a concepção de oralidade, a relação entre o discurso literário e a oralidade e a enunciação no texto literário; no quarto capítulo, estudamos como a linguagem colabora para a construção de um status, levando em consideração as formas de tratamento, os usos lexicais (que englobam também a escolha de um registro culto ou popular de acordo com a situação comunicativa) e os aspectos fonéticos e fonológicos. Todos esses elementos identificam um status ou um papel social na peça, principalmente se estudados junto com uma releitura da teoria da preservação da face realizada no fim do capítulo. Por fim, no quinto capítulo, analisamos as escolhas lexicais, as 
formas de tratamento e os aspectos fonológicos usados na peça, recursos da linguagem que tornam possível a caracterização de tipos sociais na peça $O$ Juiz de Paz da roça.

O primeiro foco da análise se dá no nível lexical, importante meio de caracterização das personagens e de indicação do contraste entre elas. O segundo foco destaca a relação do uso das formas de tratamento para a construção dos tipos sociais. As formas de tratamento são um indicativo do status que cada personagem exerce na comédia. Verifica-se, assim, a habilidade do escritor em relacionar as personagens-tipo e sua representação linguística e imagética. $O$ terceiro foco aborda os aspectos fonológicos passíveis de representação escrita presentes nos diálogos das personagens.

Abordamos também elementos não verbais apontados nas didascálias (as indicações cênicas do autor) para entender o contexto situacional da cena, elementos esses que contribuem para a representação das personagens e desenvolvem um papel tão importante quanto os elementos verbais. É por meio delas também que o autor indica ao leitor a construção da imagem das personagens, tal como afirma Goffman (2005:25), "quando um indivíduo desempenha um papel, implicitamente solicita de seus observadores que levem a sério a impressão sustentada perante eles".

Preti (2002) afirma que uma metodologia da análise de textos de ficção deve incluir duas etapas: uma "macroanálise", em que se consideram os fatores extralinguísticos e uma "microanálise", em que se consideram os fatores interacionais, nascidos da própria evolução do diálogo construído, tais como as formas de tratamento, as manifestações de poder expressas na interação, a perda ou a manutenção da face entre outros. Esta pesquisa se volta para a análise tanto 
dos fatores extralinguísticos (macroanálise) como interacionais (microanálise) do texto da peça O Juiz de Paz da roça, que constitui o corpus do trabalho.

Em Considerações Finais, fazemos algumas observações sobre os resultados mais relevantes da pesquisa.

A escolha do tema de pesquisa pode contribuir, não só para divulgar a obra do escritor Martins Pena, mas também para colaborar com outras pesquisas de Análise da Conversação no âmbito literário, em especial no que concerne ao texto teatral brasileiro de comédia.

Como a abordagem deste trabalho é da ordem da linguagem e não da área da Sociologia, são as práticas da linguagem que nos interessam, mas é lógico que levemos em consideração os dados contextuais para entender o processo de interação entre as personagens do texto. 


\section{CAPÍTULO 1: MARTINS PENA E O CONTEXTO TEATRAL BRASILEIRO NO SÉCULO XIX}

\subsection{Martins Pena: vida e obra}

Luís Carlos Martins Pena nasceu no Rio de Janeiro em 1815 e faleceu em Lisboa no ano de 1848. Na História do Brasil, esses anos compreendem o Brasil Colonial (até 1822), o Primeiro Reinado (1822-1831), Regência Trina (1831-1835), Regência Una (1835-1840) e começo do Segundo Reinado. Ele vivenciou, portanto, o desenrolar de fatos importantes no país.

Em relação à literatura, realçamos a publicação, em Paris, de Suspiros Poéticos e Saudades, de Gonçalves de Magalhães, marco do Romantismo brasileiro. Embora tenha vivido em pleno Romantismo, Martins Pena apresenta também tendências realistas recorrentes em suas comédias.

Órfão de pai e de mãe, Pena passa a viver desde cedo com o avô materno, um rigoroso tenente português e, mais tarde, com um tio. É matriculado na Aula de Comércio, porém não tem vocação. O escritor frequenta a Academia de Belas Artes, onde estuda arquitetura, pintura e cenografia. Era um homem culto, conhecedor de música e de literatura e dominava algumas línguas estrangeiras como o francês e o italiano. Além de escrever comédias, escreveu folhetins sobre espetáculos de teatro e de ópera para o Jornal do Comércio (1846-47).

Com 23 anos, ele vê a encenação de sua primeira peça pela companhia do ator João Caetano. Em 1847, o autor parte rumo ao continente europeu. Em Londres, ele exerce a função de adido e é neste período que adoece. Ele tenta voltar ao Brasil, mas acaba morrendo em Portugal, com 33 anos. 
Em 1956, o Instituto Nacional do Livro publica pela primeira vez no Brasil uma edição crítica dos manuscritos do escritor a cargo de Darcy Damasceno. Até então, eram de domínio público apenas nove comédias presentes em várias edições coletivas, uma vez que as outras comédias e os dramas do autor eram desconhecidos.

Pena criou personagens cômicos que retratavam os costumes cariocas da época e insistia em marcar tipos roceiros e provincianos em contato com a Corte, o Rio de Janeiro na época. Em relação às personagens de Martins Pena, Magaldi (1997:47) destaca:

As personagens - mais que um esboço de individualidade e menos que um caráter - agrupam-se em famílias de tipos, segundo o lugar de nascimento: cariocas, sertanejos e estrangeiros; e de acordo com a categoria profissional: juiz, caixeiro, irmão das almas ${ }^{1}$, médico, meirinho, o usurário etc.

Diferentemente das comédias, os dramas de Martins Pena pecam pela artificialidade em termos de linguagem - é comum o uso de galicismos e italianismos - e se afastam no espaço e no tempo de acordo com Magalhães Júnior (1971). Geralmente, são cenas que se desenrolam no estrangeiro (Itália, Portugal, Espanha e Inglaterra), exceto a peça Itaminda ou O Guerreiro de Tupã, que se passa na Bahia.

Apesar de escrever dramas com enfoque histórico, no ano de 1844 o dramaturgo volta aos assuntos e ao tom das primeiras comédias e nos dá uma representação tal como fazem nos romances o escritor Joaquim Manuel de Macedo. Macedo escrevia romances de costumes, em que retratava a vida cotidiana, a descrição dos hábitos dos brasileiros da época, as festas e tradições, tudo em uma

\footnotetext{
${ }^{1}$ A atividade dos "irmãos das almas" consistia em arrecadar dinheiro pedindo esmolas para as almas e para os santos. Segundo Magalhães Júnior (1971), era prática comum na época fazer coletas de dinheiro para essa finalidade, em grupos, como os da folia do Divino Espírito Santo ou individualmente, por "irmão das almas".
} 
linguagem simples e tramas fáceis. De acordo com Candido (2004), o romance no Brasil começa de fato com a narrativa de costumes do Rio de Janeiro, A moreninha (1844) de Macedo.

São nas comédias de costumes de Martins Pena, no entanto, que encontramos o retrato fiel dos costumes brasileiros.

É importante salientar que, de acordo com Bosi (1994:151), Martins Pena já fazia sentir o social bem menos conservador em relação às outras obras da mesma época e os diálogos valem como excelente testemunho da língua coloquial brasileira do Rio de Janeiro tal como se apresentava nos meados do século XIX. A respeito da linguagem, Magaldi (1997:53-62) relata:

\begin{abstract}
A preocupação com o flagrante vivo o isentou de um dos maiores defeitos da linguagem teatral, patente na dramaturgia brasileira: a oratória, o rebuscamento das frases, que roubam a espontaneidade ao diálogo. Tudo é simples na comédia de Martins Pena - a situação, o traço dos numerosos tipos, o desenvolvimento da trama, a conversa das personagens.

[...] A linguagem de Martins Pena exigiria um estudo à parte [...]. Na literatura dramática portuguesa, apenas Gil Vicente havia conseguido semelhante adequação das falas à psicologia e ao estado social das personagens. [...]

Martins Pena leva para o palco a língua do povo, e por isso o brasileiro enxerga nele, com razão, a sua própria imagem.
\end{abstract}

Prado (1999) sublinha que Martins Pena foi o nosso maior comediógrafo do período romântico, embora pela escrita teatral nada tivesse de romântico. Foi fiel ao senso da cor local. O seu poder de observação é grande e retrata a maioria dos problemas da época, tais como a desorganização dos serviços públicos, a exploração religiosa, o recrutamento de soldados para as revoltas do Sul e o contrabando de escravos, por exemplo. 
As principais obras de Martins Pena são²: O Juiz de Paz da roça, 1838 (editada em 1842); Um Sertanejo na Corte (peça inacabada, não representada e só impressa na edição crítica de Darcy Damasceno, Rio, I.N.L., 1956); Fernando ou o Cinto Acusador (id.); D.João de Lira ou O Repto (id.); A Família e A Festa da Roça, 1840 (ed.1842); D.Leonor Teles (não representada nem impressa até a edição citada); Itaminda ou O guerreiro de Tupã (id.); Vitiza ou O Nero de Espanha, 1841 (não publicado); Os Dous ou O Inglês Maquinista, 1845 (ed.1871); O Judas em Sábado de Aleluia, 1844 (ed.1846); O Irmão das Almas, 1844 (ed.1846); O Diletante, 1845 (ed.1846); Os Três Médicos, 1845 (não publicado); O Namorador ou A Noite de São João, 1845; O Noviço, 1845 (ed.1853); O Cigano, 1845 (não publicado em livro até a edição citada); O Caixeiro da Taverna, 1845 (ed.1847); As Casadas Solteiras, 1845 (não publicado em livro até a edição citada); Os Meirinhos, 1846 (não publicado); Quem casa, quer casa, 1845(ed.1847); Os Ciúmes de um Pedestre ou O Terrível Capitão do Mato, 1846 (não publicado); As Desgraças de uma Criança, 1846 (não publicado); O Usuário (não representado e nem publicado); Um Segredo de Estado, 1846 (não publicado) O Jogo de Prendas (não representado nem publicado); A Barriga de meu tio, 1846 (não publicado).

\subsection{A peça O Juiz de Paz da roça}

O Juiz de Paz da roça foi a primeira peça escrita por Martins Pena quando este tinha apenas dezoito anos. A peça foi considerada a primeira comédia do nosso país e destacou-se no cenário nacional.

\footnotetext{
${ }^{2}$ Para o estabelecimento da bibliografia de Martins Pena, foi utilizada a relação arrolada por Darcy Damasceno (1971) em sua edição crítica das comédias de Martins Pena, em que o estudioso enumera as peças pela ordem cronológica.
} 
Comédia em um ato, ela tem como pano de fundo a vida rural brasileira da primeira metade do século XIX. Retrata as confusões de uma família, quando a filha, Aninha, resolve fugir para se casar com um oportunista, José da Fonseca, e evidencia o autoritarismo de um juiz de paz. Manuel João, pai de Aninha, é lavrador e guarda nacional, encarregado de recrutar José da Fonseca para o Rio Grande, no período em que se desenrola a Guerra dos Farrapos. Pela falta de cadeias, o pai de Aninha é obrigado a levar o recruta para casa, momento propício para a fuga do casal e que acaba em casamento.

Até meados do século XIX, eram raras as peças de assunto nacional, já que muitas ainda seguiam um conteúdo mais heróico, desprovido de críticas em relação ao país.

Os principais tipos sociais criados pelo comediógrafo nesta comédia são: Manuel João, pequeno lavrador; Aninha, sua filha, o namorado José, sujeito oportunista e a figura do Juiz de Paz - que dá título à peça - responsável pelos momentos cômicos na peça. A comédia retrata o contraste entre as personagens roceiras e o Juiz de Paz. Fixa também, a posição da mulher dentro da sociedade patriarcal por meio das personagens Maria Rosa e Aninha.

De acordo com Arêas (1987), O Juiz de Paz da roça pretende articular uma estrutura de comédia clássica (o par amoroso que almeja vencer a figura do pai) a um contexto brasileiro na roça, por meio da figura arquetípica de um juiz. Segundo a autora (1987:117):

Não podemos nos esquecer que o tema da justiça, com camponeses ignorantes do sentido dos tribunais, apresentando diante de juízes seus casos insignificantes e familiares, é dos mais antigos do teatro, ao lado de outro tema presente em nossa pecinha: o do rústico que descobre a capital e fica aturdido com seu progresso. 
Desde o princípio da peça, há a relação de contraste entre as personagens de diferentes níveis sociais, tais como o Juiz de Paz, o Escrivão e as demais personagens roceiras. Embora personagens da peça e trabalhadores da roça, os negros nem nome tinham, pois na época, ainda prevalecia o regime escravocrata. $\bigcirc$ Juiz de Paz e o Escrivão são caracterizados pelas suas funções profissionais e são por meio de seus respectivos papéis na peça que supomos um nível de instrução superior às demais personagens.

Trata-se de uma crítica do autor aos costumes brasileiros da época, e a figura do juiz representa a autoridade perante a ignorância das personagens roceiras. Heliodora (2000:13) salienta que Pena fez um primoroso retrato do Brasil de seu tempo e que o dramaturgo teve clara postura crítica a respeito de falhas sociais, morais e políticas que conheceu. Para compreendermos um pouco o que se passava no período, traçamos um breve panorama do século XIX no Brasil e no teatro.

\subsection{0 século $\mathrm{XIX}$ : O teatro no Brasil}

D.João VI chegou com sua corte ao Rio de Janeiro em 1808 e permaneceu até 1821 , trazendo para a colônia um grande desenvolvimento comercial, cultural e artístico. É nesse período que temos a abertura dos portos (1808) e a inauguração do Museu Nacional de Belas Artes, por exemplo. Destacam-se nessa época a criação das faculdades de Direito de São Paulo, o Supremo Tribunal, a Guarda Nacional e o Instituto Histórico e Geográfico entre os anos de 1820-1840.

Esses anos, porém, não foram só de desenvolvimento para o país, mas também de revoltas. Os movimentos revolucionários começam pelas guerras da 
Independência e pelos movimentos separatistas. Era claro o patriotismo nas províncias de Minas Gerais, Rio, São Paulo, Rio Grande do Sul e Santa Catarina.

A figura dominante do pater-famílias como autoridade suprema da família era um fato na época. A mulher casava cedo, vivia confinada e sem capacidade de governo doméstico, tal como destaca Moreira (apud Biderman 1972/1973). No que concerne à vida das mulheres na época, Freyre (2008:87) salienta que o brasileiro da década de 1850 era um verdadeiro patriarca à maneira romana em relação à sua esposa. De acordo com o pesquisador, os meados do século XIX constituem época ideal para a interpretação do sistema patriarcal no Brasil, por ter sido o período em que tivemos a manifestação de vários tipos de patriarcalismo brasileiro, tais como o agrário, o pastoril e o urbano. O casamento, por exemplo, não era resultado de flertes românticos, mas de um sistema patriarcal de família.

O Brasil era constituído de diferentes grupos sociais, resultados do desenvolvimento das cidades e da economia. Freyre (2008) destaca que os brasileiros mais sofisticados da época inspiravam-se nos ingleses e nos franceses, fato também mostrado por meio das peças teatrais $O$ Juiz de Paz da roça e Os dous ou O Maquinista Inglês de Martins Pena.

Em relação à estrutura econômica da sociedade brasileira, encontramos, de um lado, uma classe de proprietários de terra e de escravocratas; de outro, a massa de escravos. Freyre (2008:64) assinala também a presença de alguns "pequenos burgueses" e de pequenos lavradores. A terra era propriedade dos plantadores de café e, no Sul, dos criadores de gado. Os roceiros formavam a classe dos pequenos fazendeiros, entre os quais muitos eram escravos alforriados. É nesse contexto brasileiro em que a peça $O$ Juiz de Paz da roça está inserida. 
Durante esse período, ocorreu o desenvolvimento do teatro no Brasil. Houve uma grande influência de tudo o que era estrangeiro, sobretudo em relação às óperas italianas e ao teatro francês.

A decoração teatral era a base de uma cenografia pintada, com desenhos no fundo e em perspectivas, que ambientavam a cena. A maioria dos objetos no palco, no entanto, não podia ser usada. Nesse sentido, Arêas (1987:13) afirma que "se um ator se apoiasse a uma árvore, ou tocasse levemente o pano de fundo, como observa Martins Pena, toda a paisagem, isto é, a 'vista', começaria a oscilar”.

Como era de se esperar, a falta de experiência teatral no Brasil fez com que Martins Pena relatasse que, geralmente, o pano de fundo representava algo apropriado à peça, embora os bastidores mantivessem pinturas utilizadas em outros espetáculos que, com ele, não combinavam.

O Juiz de Paz da roça conta com dois cenários distintos, o que não era um grande problema se os contra-regras e os maquinistas trocassem rápido o mobiliário. Basicamente, a cena desenrola-se em uma sala de residência rural de um lavrador, Manuel João, membro também da Guarda Nacional e na sala de um juiz de paz.

Além desses problemas com o cenário, Arêas (1987) afirma que, geralmente, o palco era em declive para facilitar a visibilidade dos atores e a iluminação era muito mais fraca que a de atualmente. A iluminação era precária tanto no palco, quanto no auditório e a fumaça do lustre de velas irritava os olhos dos espectadores e dificultava a visão. Martins Pena era muito detalhista e crítico do teatro na época, a tal ponto que Arêas (1987:21-22) sublinha:

A irritação do folhetinista a respeito da falta de profissionalismo teatral (ensaios insuficientes, esquecimento de papéis, atores que riem em momentos sérios por alguma graça dita pelo ponto, esse mesmo ponto que levanta a cabeça da caixa para cumprimentar conhecidos na platéia, etc.etc. etc.) tem a ver, indubitavelmente, com 
o fato de que a ópera, com a interrupção de 12 anos que entre nós sofrera no início do século, podia ser considerada como de importação recente no Brasil. Não haveria aqui, portanto, uma estrutura pronta que a abrigasse, nem pessoal especializado.

No século XIX, o palco à italiana ${ }^{3}$ ocupava uma posição de destaque e dominou também na primeira metade do século XX. De acordo com Arêas (1987:13):

Com suas separações evidentes, o teatro como um todo espelhava a hierarquia social, e a acústica ou qualidade desigual dos lugares nem sempre derivava de uma impossibilidade técnica. Fazendo parte dessa estrutura, o palco à italiana construía uma barreira não menos evidente entre os espectadores e os atores, ou seja, estabelecia claramente uma ruptura entre cerimônia e jogo.

O teatro e a igreja tornaram-se uma espécie de passeio, uma reunião social, um divertimento no Rio de Janeiro da época. É justamente neste período que a prática do entremez ${ }^{4}$ chega ao Brasil e ganha destaque no Rio de Janeiro. Martins Pena aproveita para incorporá-lo em seu teatro, acrescentando cor local e o gosto pelo pitoresco. A ação do entremez usava personagens caricaturais, disfarces, tudo permeado por confusões durante o desenvolvimento da ação. Martins Pena revelava uma tendência jornalística ao mesmo tempo em que trabalhava a comicidade na rotina do brasileiro. Segundo Prado (1999:60), o dramaturgo dividiu o Brasil em diversos Brasis que coexistiam no tempo: o da corte, o da roça e o do sertão.

Em termos de literatura geral, esta apresentou no século XIX notável enriquecimento. Martins (1988) afirma que a atividade literária dos escritores do

\footnotetext{
${ }^{3}$ O palco é o local para a apresentação de artistas em peças de teatro, dança, entre outros. Os palcos são construídos com três tipos básicos: palco italiano, palco de semi-arena e palco de arena. No palco italiano, os espectadores ficam apenas de frente e, geralmente, ele se situa mais distante da plateia.

${ }^{4}$ Segundo Moisés (2004), o entremez consistia em breves encenações de jograis ou bufões, realizadas entre um prato e outro dos banquetes fidalgos durante a Idade Média. Tornou-se, com o tempo, um gênero autônomo, realizado por processos realistas, próximo da comédia de costumes.
} 
século XIX se expande em múltiplos gêneros e eles aproveitam a linguagem de diferentes regiões e camadas sociais. De 1840 a 1880, temos o florescimento do Romantismo com inovações e a busca de uma expressão linguística brasileira. Trata-se de uma época de transição, pois muitos escritores começaram a se preocupar em dar um efeito de real ao texto e em se afastar dos moldes clássicos da literatura até então vigentes antes do Romantismo.

De acordo com Martins (1988:13):

Alguns autores se revelam mais preocupados com a elaboração estilística, outros se satisfazem com uma expressão mais chã, uma transcrição da linguagem falada corrente; uns são mais ortodoxos, outros menos, em relação às normas gramaticais; uns reproduzem o falar urbano, outros se interessam em registrar o falar regional; uns são mais contidos, sóbrios, outros mais derramados e verbalistas; e vários há que revelam notável versatilidade, apresentando variações estilísticas em adequação à natureza da obra.

Escrita em pleno século XIX, a peça O Juiz de Paz da roça não só retrata os costumes da época, mas também evidencia os usos linguísticos do período, sobretudo do ponto de vista da oralidade. O autor representa as marcas da oralidade em seu texto ao mesmo tempo em que emprega marcas da escrita mais formal. Em O Juiz de Paz da roça, estas marcas aparecem, sobretudo, na figura do Juiz de Paz e do Escrivão. A fala de ambos é permeada de termos técnicos relativos ao mundo das leis e o escrivão lê vários requerimentos, tipo textual caracterizado pela formalidade da língua escrita. Os requerimentos apresentam uma estrutura formal, embora nem sempre o conteúdo expresso seja condizente com o tipo textual de um requerimento. Assim, temos pequenos textos desse tipo dentro de um texto principal, que é a peça teatral.

Antes do estudo propriamente dito da comédia, é importante entender as características das duas principais vertentes do texto teatral: a comédia e o drama. 


\section{CAPÍTULO 2: AS CARACTERÍSTICAS DO TEXTO TEATRAL}

\subsection{O texto teatral: a comédia e o drama}

Do grego théatron, o teatro designa o lugar onde se vê e onde se assiste a um espetáculo. Além de indicar o lugar destinado à representação de obras dramáticas ou espetáculos públicos, o teatro também é um trabalho escrito por um autor para ser dramatizado, ou seja, existem duas instâncias de texto: um texto escrito para ser lido por um leitor e um texto para ser encenado por um ator e dirigido por um diretor, responsável por adaptar a obra literária para o palco. Basicamente, há dois tipos de texto teatral: a comédia e o drama.

De acordo com Aristóteles em sua Poética, a tragédia imita os homens melhores do que eles ordinariamente são e a comédia imita os piores no teatro clássico. Na atualidade, Pavis (2008) também define a comédia em oposição à tragédia. Para ele, a primeira possui personagens de condição modesta e com desenlace feliz; sua finalidade principal é provocar o riso do espectador. A segunda representa homens eticamente superiores cuja situação tem por objetivo suscitar a comoção.

A comédia, por sua vez, de acordo com Prado (1999), se distingue em alta e baixa comédia. A alta comédia usa sutilezas de linguagem, jogos de palavras, e a baixa comédia usa procedimentos de farsa, de comicidade visual.

No Brasil, ao movimento romântico seguiu o realismo-naturalismo. Como os movimentos estético-literários não são estanques, as tendências realistasnaturalistas já se encontravam presentes no desenvolvimento do Romantismo. Os textos da comédia brasileira do período romântico estão mais próximos de um estilo 
realista-naturalista, uma vez que denunciam e tratam de vários problemas da família e dos hábitos da sociedade na época, sobretudo do Rio de Janeiro.

De acordo com Cafezeiro e Gadelha (1996:209), as peças de Martins Pena seguem a linha da baixa comédia em oposição à alta comédia de Alencar. A alta comédia ainda seguia a tradição do teatro realista francês e não admitia termos de baixo calão e gírias, diferentemente da baixa comédia.

Para esses autores, conforme o conteúdo da ação, há tipos intermediários como o melodrama ${ }^{5}$, a tragicomédia ${ }^{6}$ e a comédia de costumes.

A comédia de costumes é o estudo do comportamento do homem em sociedade, das diferenças de classe e de caráter. Martins Pena soube como ninguém retratar personagens de diferentes tipos sociais em cena. A esse respeito, Cafezeiro e Gadelha (1996:106) reafirmam:

Dentro da amplitude de temas abordados pela comédia brasileira, notável é também a variedade de tipos: do urbano ao roceiro, do rico ao pobre, do nobre ao plebeu, do perdulário ao avarento, do bonachão ao sisudo, do branco estrangeiro ao crioulo nacional, das prostitutas às madames, das mocinhas casadoiras às adúlteras, do "bom moço" ao interesseiro.

O cômico caracteriza-se pela inovação e pela crítica de atitudes da época e se revela também uma alternativa para retratar e criticar a sociedade. Este meio de retratar o Brasil no período depende de um trabalho primoroso do autor, que ganha forma por meio da criação das personagens, as personificações dos tipos sociais existentes no país.

\footnotetext{
${ }^{5}$ De acordo com Pavis (2008:238), "o melodrama é um gênero que surge no século XVIII, aquele de uma peça - espécie de opereta popular - na qual a música intervém nos momentos mais dramáticos para exprimir a emoção de uma personagem silenciosa".

${ }^{6}$ Segundo Pavis (2008:420), a tragicomédia é uma "peça que participa ao mesmo tempo da tragédia e da comédia".
} 


\subsection{A estrutura do texto teatral}

Neste segmento, analisamos a estrutura do texto teatral correspondente ao texto escrito e oralizado no palco. Há uma grande diferença entre o texto escrito e o oralizado no palco. O primeiro demanda um esforço de imaginação do leitor, enquanto o segundo implica uma experiência sensorial entre as personagens e o público. São dois tipos de mimetização do real, porém com um impacto diferente para o leitor/espectador.

O texto de teatro define-se por uma finalidade vocal, recitativa e representativa, segundo Oesterreicher (1996:330). Há um aumento da espontaneidade, quando o texto é encenado, uma vez que existe uma presença direta do ator perante o público. Os movimentos corporais garantem a dinamicidade de uma cena. Todas as hesitações, as repetições e as interrupções presentes no teatro oralizado no palco fazem parte da natureza da troca verbal de um diálogo comum real.

Segundo Assumpção (2010), o termo "texto dramático" remete a dois sentidos diferentes. De um lado, a acepção mais comum é a literária e, de outro, enquanto escrita que carece de palco, é pura virtualidade que só a representação cênica atualizará. Ler peças de teatro não significa assistir a peça. São movimentos diferentes de compreensão do fenômeno teatral.

Em relação ao teatro (escrito ou oralizado no palco), na tabela a seguir, observamos as seguintes características: 


\begin{tabular}{|c|c|}
\hline $\begin{array}{l}\text { Texto de teatro escrito (Roteiro ou } \\
\text { script) }\end{array}$ & Texto de teatro oralizado no palco \\
\hline $\begin{array}{l}\text { Conta uma história por meio de um } \\
\text { texto. }\end{array}$ & $\begin{array}{l}\text { Conta uma história por meio de um texto e } \\
\text { de uma ação concreta (presença física dos } \\
\text { atores). }\end{array}$ \\
\hline $\begin{array}{l}\text { Presença de didascálias (indicações } \\
\text { cênicas do autor. Para estudo mais } \\
\text { detalhado das didascálias, vide } \\
\text { seção 2.3) }\end{array}$ & $\begin{array}{l}\text { Ausência de didascálias (indicações } \\
\text { cênicas do autor). } \\
\text { Uso de recursos paralinguísticos } \\
\text { Figurino/ Cenário }\end{array}$ \\
\hline $\begin{array}{l}\text { Descrição minuciosa do espaço por } \\
\text { meio das didascálias. } \\
\text { A ação geralmente é concentrada em } \\
\text { um só espaço. }\end{array}$ & $\begin{array}{l}\text { Espaço concreto, que se impõe à visão do } \\
\text { espectador em todos os detalhes. } \\
\text { A ação geralmente é concentrada em um } \\
\text { só espaço. }\end{array}$ \\
\hline $\begin{array}{l}\text { Não se pode falar em foco narrativo } \\
\text { (1ํa e } 3^{\underline{a}} \text { pessoas) no texto teatral. }\end{array}$ & $\begin{array}{l}\text { Não se pode falar em foco narrativo } \\
\text { (1 }{ }^{a} \text { e } 3^{\underline{a}} \text { pessoas) no texto teatral. }\end{array}$ \\
\hline
\end{tabular}

No teatro, as personagens constituem a totalidade da obra, uma vez que nada existe sem elas. A história dispensa a mediação do narrador.

Segundo Urbano (2008), o texto teatral possui duas faces, que se realizam por meio de dois tipos de textos: um texto escrito (roteiro ou script) para ser falado ou à espera de voz viva e outro oralizado no palco como encenação do roteiro. $\mathrm{O}$ texto teatral apresenta semelhanças e particularidades em relação aos diálogos naturais e espontâneos, mas também em relação aos diálogos das narrativas literárias. Para Kerbrat-Orecchioni (1984), ao contrário do texto romanesco, o texto teatral se caracteriza por uma sequência estruturada de réplicas tomadas por 
diferentes personagens que entram em interação, isto é, como uma espécie de "conversação", tal como uma interação face a face ${ }^{7}$.

Os diálogos reais podem ser formais ou informais, com intercâmbio direto e alternância de papéis. Há dois tipos de diálogos: os assimétricos, em que ocorre o comando por parte de um falante, com poucos pares adjacentes ${ }^{8}$ e os simétricos, em que não há domínio de um locutor e em que ocorrem com mais frequência os pares adjacentes. Outra maneira de se compreender esses tipos de diálogos ocorre com a questão do tempo em que o falante detém a palavra; quando há predomínio do maior tempo de fala por parte de um dos falantes, o diálogo é assimétrico.

É necessário salientar que, no texto teatral, há também o monólogo e o aparte $^{9}$. O primeiro se caracteriza pela ausência de troca direta e de alternância de papéis. É possível encontrar peças baseadas somente em um monólogo da personagem única, ou seja, ela não entra em interação com outra personagem, mas deve monologar em voz alta para o público. O aparte é um "discurso da personagem que não é dirigido a um interlocutor, mas a si mesma (e, consequentemente ao público)", nas palavras de Pavis (2008:21). O aparte se distingue do monólogo por "sua brevidade, sua integração ao resto do diálogo". Trata-se de um diálogo direto com o público, que assinala a verdadeira intenção da personagem. Para ser realizado, há um afastamento do ator ou uma mudança de entonação junto com um olhar para a plateia.

\footnotetext{
${ }^{7} \mathrm{~A}$ interação face a face acontece em um contexto em que os participantes da interação estão presentes e partilham o mesmo sistema linguístico, e referencial de tempo e de espaço.

${ }^{8}$ Os pares adjacentes são uma sequência de dois turnos em que um primeiro falante projeta e requer um segundo turno complementar produzido por outro falante. Temos, por exemplo, perguntas e respostas, oferta e aceitação.

9 Nas peças de Martins Pena, o "aparte" é grafado "à parte".
} 
Não se dialoga no teatro como na vida cotidiana, não é necessário assumir esses diálogos representados por reproduções perfeitamente miméticas das trocas comunicativas que temos na vida cotidiana.

Segundo Urbano (2008:195), as falas fabricadas para um script teatral moderno e as mesmas falas posteriormente dramatizadas no palco evidenciam estratégias conversacionais idealizadas, mais artificiais no texto escrito mais naturais quando oralizadas em cena. O autor teatral dá um texto escrito ao ator e este deve retribuir um texto oralizado (com todas as implicações fonéticas e prosódicas, compreendidos ainda os gestos e a proxêmica ${ }^{10}$ ) ao texto daquele. Os atores, assim, vivificam suas falas e os gestos encaminham e complementam para a direção desejada da "conversação".

Para Pavis (2008) a cenografia insere o espaço cênico em um determinado meio. O cenário também pode ser construído por meio dos sons, para complementar o visual. Pode ser um dispositivo para esclarecer o texto e a ação humana. Ingarden (1988) não pensa diferente e também destaca que a linguagem é auxiliada pelo aspecto visual no teatro, especialmente no que concerne aos estados psíquicos das personagens representadas.

De acordo com Ingarden (1988:153):

A constatação essencial que nos introduz em toda a problemática da linguagem no teatro é que o "texto principal"1", tomado em seu conjunto, constitui um elemento do universo representado no espetáculo teatral. A enunciação de cada palavra, de cada frase, torna-se logo um processo que se desenvolve neste universo e, em especial, uma parte do comportamento da personagem representada.

\footnotetext{
${ }^{10}$ Segundo o dicionário Houaiss, a proxêmica é o "estudo das distâncias físicas que as pessoas estabelecem espontaneamente entre si no convívio social, e das variações dessas distâncias de acordo com as condições ambientais e os diversos grupos ou situações sociais e culturais em que se encontram."

${ }^{11}$ Ingarden (1988) entende por "texto principal" as palavras pronunciadas pelas personagens no teatro enquanto as didascálias (indicações cênicas do autor para o leitor/diretor) formam um texto secundário.
} 
Para Ingarden, embora no teatro os atos das personagens sejam fundamentais na dramatização, os elementos complementares do universo representado podem ter tal importância que sua ausência não só tornaria o espetáculo teatral incompreensível, como o privaria de momentos essenciais para a ação dramática. O autor (1988:157) ainda afirma:

O diálogo, entretanto, muito raramente se reduz a uma pura comunicação: o jogo é muito mais vital, pois se trata de exercer uma influência sobre aquele a quem o discurso se dirige. Em todo o conflito "dramático", que se desenvolve no universo representado no espetáculo teatral, o discurso endereçado a uma das personagens é uma forma de ação do locutor e só tem, no fundo, uma significação real nos eventos apresentados no espetáculo, quando contribui de modo decisivo para impulsionar a ação.

Pavis (2008), por exemplo, define a ação como uma sequência de acontecimentos cênicos produzidos em função do comportamento das personagens. A ação se situa também no interior da personagem e influencia as personagens em decisões e em seus discursos.

\subsection{Didascálias: usos e funções no texto teatral}

As didascálias, também conhecidas como rubricas, são o estrato do texto teatral não pronunciado em cena em uma representação, mas estão presentes no roteiro do texto teatral. Elas englobam ao mesmo tempo as indicações cênicas, a menção de identidade das personagens, o modo de elocução dos emissores ${ }^{12}$ e o lugar de enunciação para a boa compreensão do contexto de uma peça. O contexto de uma peça ou de uma cena é o conjunto de circunstâncias que rodeiam a emissão

\footnotetext{
12 Neste trabalho, em função das várias teorias, os termos autor, enunciador, emissor, falante e locutor, guardados os devidos enquadramentos e deslocamentos teóricos, são empregados para designar o sujeito que organiza a enunciação em primeiro lugar. Para aquele a quem é dirigido a enunciação, empregamos os termos interlocutor, receptor, ouvinte e enunciatário.
} 
do texto linguístico e evidenciam o espaço, o tempo, os dêiticos ${ }^{13}$ e os temas da enunciação, esclarecedores da mensagem linguística. Esse conhecimento é indispensável para que o espectador compreenda o texto e a representação.

No roteiro de teatro, se o dramaturgo dá sua própria voz a suas personagens e a seus atores, sua própria voz está sempre presente, mesmo de uma maneira menor, pelas didascálias. Geralmente destacadas em itálico (com ou sem parênteses), as didascálias marcam, especificamente, essa distinção entre a voz da personagem e a voz do autor. Desse modo, o texto teatral comporta dois canais, uma dupla enunciação: aquela do dramaturgo e aquela dos atores. Levando em consideração esses aspectos, o modo de leitura do texto teatral é influenciado e mesmo orientado por esta camada textual secundária a qual chamamos de didascália.

Para o desenvolvimento da ação, a consideração das didascálias é fundamental. Elas têm um estatuto paradoxal, já que constituem em parte a singularidade do texto teatral em oposição aos outros discursos literários. Elas podem ser assim, uma ligação entre o teatro e o romance. No entanto, na representação do palco, elas não existem.

As funções verbais do discurso didascálico correspondem a quatro questões fundamentais: Quem fala? A quem se fala? Como se fala? e Onde se fala?. São funções subordinadas ao diálogo e orientam para o entendimento do contexto da peça. Os códigos visuais designados pelas didascálias podem, ao menos se forem referidos no texto pronunciado, gozar de autonomia, orientando menos nossa leitura do texto teatral.

\footnotetext{
${ }^{13}$ Os dêiticos são elementos linguísticos que fazem referência ao falante, à situação de produção de um dado enunciado ou mesmo ao momento em que o enunciado é produzido. Em geral, funcionam como dêiticos os pronomes pessoais e demonstrativos, bem como os advérbios de lugar e de tempo, elementos que se encarregam de situar o contexto espaço-temporal.
} 
Os destinatários da voz do autor são múltiplos no texto de teatro, visto que os diálogos e as didascálias se destinam ao diretor, aos atores e aos leitores. As didascálias também têm outra função: aquela de um metatexto. Sendo normalmente subordinada ao diálogo, elas exercem o papel de comentar e de esclarecer. São de certa medida o equivalente teatral da função metanarrativa do discurso romanesco. No exemplo sublinhado a seguir, a didascália explica a reação da personagem diante de outra personagem, o que enfatiza ainda mais este tipo de função metanarrativa:

Gainer - Mi não diz isso... Eu pensa na home que será sua marido.

Clemência, à parte - Bom ... (Para Gainer:) A única cousa que me embaraça é a escolha. Eu ... (À parte:) Não sei como dizer-lhe .... (Para Gainer:) As boas qualidades ... (Gainer, que já entendeu a intenção de Clemência, esfrega à parte, as mãos de contente. Clemência, continuando:) Há muito que o conheço, e eu ... sim ... não se pode ... o estado deve ser considerado, e ... ora... Por que hei-de eu ter vergonha de o dizer? ... Sr.Gainer, eu o tenho escolhido para meu marido; se o há-de ser de minha filha, seja meu ...

(Cena XXV. Os dous ou O Inglês Maquinista, Martins Pena)

De acordo com Issacharoff (1985), é necessário considerar as diversas funções das didascálias dentro de um texto teatral. Primeiramente, todo o texto teatral fornece sempre a identidade do enunciador com ou sem informações complementares - o que podemos nomear de função nominativa. Nas farsas, este elemento pode ser retomado no diálogo, em que o nome próprio pode designar ao mesmo tempo os atributos daquele que o porta. Um exemplo é a personagem Negreiro, na peça Os dous ou O Inglês Maquinista do próprio Martins Pena. Na peça, Negreiro é o negociante de negros novos, portanto o seu nome faz menção ao tráfico negreiro.

Gainer - Ladrão!

Negreiro - Toma lá, inglesinho! (Dá-lhe por trás.)

(Cena XXVI. Os dous ou O Inglês Maquinista, Martins Pena) 
Se as didascálias assinalam aquele que fala, elas indicam também aquele a quem nos endereçamos. A segunda função é aquela a qual Issacharoff (1985) denomina destinadora, correspondendo aos enunciados do tipo "Personagem $\mathrm{X}$ à Personagem Y" ou "Personagem X, sozinha" e às vezes "Personagem X, à parte", como nos exemplos a seguir. No primeiro exemplo, o enunciado é do tipo "Personagem X à Personagem Y":

Felício, para Alberto - Morro de impaciência por saber como pôde meu tio escapar das mãos dos rebeldes para nos fazer tão felizes.

Alberto - Satisfarei com vagar a tua impaciência.

(Cena XXVIII, Os dous ou O Inglês Maquinista, Martins Pena)

No próximo exemplo, o enunciado é do tipo "Personagem X sozinha":

Felício, só - Quanto eu amo! Dous rivais! Um negociante de meia-cara e um especulador....."

(Cena III, Os dous ou O Inglês Maquinista, Martins Pena)

No terceiro exemplo, o enunciado é do tipo "Personagem X à parte":

Felício, à parte - Velhaco!"

(Cena V, Os dous ou O Inglês Maquinista, Martins Pena)

Além dessas funções, é importante destacar outra função, a nomeada de locativa. Trata-se daquela que fornece precisões sobre o lugar cênico onde se deve realizar o ato de fala. Esta função é bem localizável no texto, na medida em que sua parte essencial figura mais frequentemente no começo do texto (antes do diálogo), seja no começo do ato se a peça contiver várias mudanças de cenário, seja no início 
de um texto de único ato, como no exemplo retirado da mesma peça, Os dous ou $O$ Inglês Maquinista:

\section{Ato único}

O teatro representa uma sala. No fundo, porta de entrada; à esquerda, duas janelas de sacadas, e à direita, duas portas que dão para o interior. Todas as portas e janelas terão cortinas de cassa branca. À direita, entre as duas portas, um sofá, cadeiras, uma mesa redonda com um cadeeiro francês aceso, duas jarras com flores naturais, alguns bonecos de porcelana; à esquerda, entre as janelas, mesas pequenas com castiçais de mangas de vidro e jarras com flores. Cadeiras pelos vazios das paredes. Todos estes móveis devem ser ricos.

\section{(Os dous ou O Inglês Maquinista, Martins Pena)}

Quando a didascália indica entonação e a atitude do locutor, Issacharoff (1985) a chama de função melódica. No teatro dos séculos XIX e XX, as anotações desse tipo de didascália são frequentes e detalhadas. No exemplo, abaixo, a personagem deve dar uma entonação que está zangada, ao mesmo tempo em que ela mostra uma atitude agressiva com a outra personagem, a sua interlocutora no excerto a seguir:

Clemência, à parte - Era dela que ele gostava! E eu, então? (Para Mariquinha: ) O que estão vocês aí bisbilhotando? As filhas neste tempo não fazem caso das mães! Pra dentro, pra dentro!

Mariquinha, espantada - Mas mamã...

Clemência mais zangada - Ainda em cima respondona! Pra dentro! (Clemência empurra Mariquinha para dentro, que vai chorando.)

(Cena XVI, Os dous ou O Inglês Maquinista, Martins Pena)

A resposta do interlocutor pode ser de dois tipos no teatro: verbal e não verbal. Se ela for verbal, o texto comportará uma réplica; se ela for não verbal, tratarse-ia de uma referência à atitude da personagem, que indica emoção manifesta (risos, lágrimas, etc.) mímica ou gesto, tal como no exemplo dado. 
Em resumo, o conjunto das funções verbais das didascálias é: nominativa, destinadora, melódica e locativa. Ainda há as funções visuais, que concernem seja ao modo de encenação do ator (gesto, mímica, movimento), seja a sua aparência física (roupa, maquilagem, penteado). Issacharoff (1985) salienta que essas não são propriamente funções, mas códigos visuais, que se poderiam reagrupar sob a denominação de função cenográfica.

Em relação ao movimento e ao gesto, podemos distinguir grosso modo duas categorias: o gesto e o movimento, que substituem a fala e aqueles que a acompanham. As mesmas observações aplicam-se às didascálias de mímica, que podem tanto substituir, quanto acompanhar a fala.

As didascálias vestimentárias contribuem com a caracterização no teatro tradicional. Quanto a outras possibilidades combinatórias do discurso didascálico, não podemos esquecer que os elementos do cenário (móveis, acessórios) são frequentemente pretexto a indicações de movimento e de gestos. Por outro lado, o código verbal principal - o diálogo - pode sempre se referir explicitamente a elementos do discurso didascálico e, neste caso, é o referente didascálico que é colocado em evidência, para o leitor do texto teatral.

Com este estudo das funções, Issacharoff (1985) salienta que as didascálias exercem grande importância no texto teatral tanto para o leitor quanto para o diretor. As funções visuais do discurso didascálico não se referem a outro discurso, trata-se simplesmente de uma informação em um código paralelo - cinésico, gestual, vestimentário, fisionômico e cenográfico. Ainda é necessário precisar que esses cinco códigos podem ou não ser subordinados a outra camada verbal do texto: o diálogo. Eles acompanham o diálogo, complementando-os, ou ficam autônomos, quando eles substituem um código verbal. 


\subsection{A personagem teatral}

O texto de teatro é concebido para ser oralizado em cena e, a partir deste aspecto, há de se considerar a importância física do ator. É por meio dele que o texto de teatro é transmitido e representado verbalmente, sustentado com gestos e complementado com a cenografia.

Para a construção da personagem, o autor reúne traços dos seres humanos, o que lhes dá existência e veracidade dentro do texto e do palco e suscita credibilidade por parte do público. Por meio dos recursos de linguagem de que dispõe o autor, ele cria a ilusão da existência de espaços e de personagens reais.

A primeira visão que temos na dramatização de uma cena é a aparência física da personagem. O escritor levanta traços que compõem a figura física da personagem, inserida em um espaço fictício. No teatro, tudo é transmitido e representado verbalmente, além de ser complementado com os gestos e com a cenografia. A personagem deve ser definida coerentemente com o que é mostrado, tanto pelo narrador em um romance quanto em um texto teatral encenado por um ator ou lido por um leitor comum.

Segundo Brait (2000), durante muito tempo, em teoria literária, discutiu-se o conceito de semelhança existente entre personagem e pessoa, conceito centrado nos estudos aristotélicos. Aristóteles aponta em sua Poética dois aspectos essenciais referentes às personagens na literatura: a personagem como reflexo da pessoa humana e a personagem como construção, que obedece às leis que regem o texto. A personagem continua sendo vista como ser antropomórfico cuja medida de avaliação é o ser humano. 
A personagem delineia-se aos olhos do leitor / espectador graças aos recursos oferecidos pelos códigos verbais e não verbais no teatro oralizado no palco.

No texto de ficção em geral, o autor busca na linguagem as características do mundo fictício a fim de criar a materialidade das personagens. O texto é, então, o dado concreto capaz de fornecer os elementos utilizados pelo escritor para dar consistência à sua invenção e estimular as reações do leitor. Brait (2000:52) salienta:

[...] é possível detectar numa narrativa as formas encontradas pelo escritor para dar forma, para caracterizar as personagens, sejam elas encaradas como pura construção linguístico-literária ou espelho do ser humano.

De acordo com Pallottini (1989), é importante atentar-se à caracterização social das personagens e de que forma elas se inserem em seu grupo, principalmente no que concerne à profissão, à situação de família, às convicções políticas e morais entre outros.

Há vários tipos de personagens no mundo da ficção. Existem personagens classificadas como redondas, ou seja, são complexas, dinâmicas, multifacetadas e apresentam várias qualidades ou tendências. As personagens planas, por sua vez, são construídas em torno de uma só ideia ou qualidade. Em geral, são definidas em poucas palavras.

As personagens-tipo, a principal motivação desta pesquisa, são personagens planas. Pavis (2008:275) entende que, como tipo de personagem, o papel está ligado a uma situação ou a uma conduta geral. A personagem reúne várias propriedades tradicionais e típicas de determinado comportamento ou classe social. 
Sobre o processo de construção das personagens-tipos do teatro de Martins Pena, Magaldi (1997:49-50) destaca:

$\mathrm{Na}$ fixação dos numerosos tipos sociais, ele [Martins Pena] adotou um processo realista, em muitos aspectos semelhante ao de outros dramaturgos que o precederam, no estrangeiro. Ele utilizou um instrumento universal especialmente para a realidade brasileira, 0 que provoca o sabor e a atmosfera convincente de suas criações.

É importante diferenciar as personagens-tipo das personagens caricaturais, uma vez que estas últimas possuem uma qualidade ou uma ideia única levada ao extremo e provocam uma distorção propositada, geralmente a serviço da sátira, de acordo com Moisés (2004). A personagem-tipo, por sua vez, possui peculiaridades sem causar uma deformação.

A personagem de ficção é designada por meio de um nome próprio fictício ou pela função que exerce na narrativa ou na peça teatral. O escritor pode trabalhar a linguagem de forma a apresentar a personagem antecipadamente por meio de um adjetivo ou de uma profissão.

Dentro de um texto, as personagens podem exercer a função de personagem principal (protagonista) ou de personagens secundárias e/ou antagônicas.

É o código verbal que materializa as personagens no texto fictício. O autor obtém mais credibilidade por parte do público se a linguagem for bem trabalhada e se coincidir com aquela que o público utiliza. Nesse sentido, o século XIX destaca-se por ter sido uma época precursora das marcas de oralidade no texto de ficção no Brasil, ou seja, a representação da língua falada. 


\section{CAPÍTULO 3: A ORALIDADE E AS MÚLTIPLAS FALAS NO TEXTO TEATRAL}

\subsection{O conceito de oralidade e de escrituralidade}

Oralidade e escrita são práticas e usos da língua com características específicas, mas não são tão antagônicas a tal ponto de se caracterizarem como dois sistemas linguísticos e nem como uma dicotomia. A fala é adquirida naturalmente em contextos informais e nas relações sociais rotineiras e a escrita, por sua vez, é adquirida em situações formais, ou seja, na escola. Fala e escrita não devem ser estudadas de forma dicotômica; a primeira não é sinônimo de erro e de desrespeito gramatical e a segunda nem sempre é o lugar de norma e do bom uso da língua.

Há muitos textos produzidos nos mais diversos domínios discursivos ${ }^{14}$ que se mesclam sob muitos aspectos, por vezes constituindo um domínio misto, os quais denominamos textos híbridos. A análise da fala e da escrita deve considerar as condições e as circunstâncias de produção das estratégias na formulação e na verbalização dos textos produzidos, sobretudo em relação ao discurso literário.

De acordo com Urbano (2011a:15), a linguagem verbal é uma utilização da faculdade de se exprimir por meio das palavras para se comunicar com outros indivíduos e compreende não só o aspecto sonoro da emissão vocal, mas também o aspecto gráfico da produção escrita. Nesse sentido, para a decodificação de uma mensagem entre um locutor e um interlocutor, é necessário considerar também outros aspectos, destacados por estudiosos como o fisiológico (deficiência na

\footnotetext{
${ }^{14}$ Para Maingueneau (2006), os domínios discursivos são equivalentes aos diversos campos do saber que geram um discurso específico, tais como o domínio da ciência, da propaganda, do jornalismo, entre outros.
} 
audição, dificuldade na articulação das palavras), o aspecto linguístico (decodificar a mensagem com base na cultura e nas experiências linguísticas do receptor) e o aspecto psicológico (estado emocional e comportamento dos participantes do ato de fala).

Embora muitos pesquisadores definam oralidade apenas como sinônimo de língua falada, adotamos neste trabalho o conceito de oralidade de Koch e Oesterreicher (1985). Eles partem de duas perspectivas para tratar a língua falada e a língua escrita: o critério do meio (ou canal) de um lado e o da concepção do outro. Usam os conceitos de fônico e gráfico para a definição do meio e, para a definição da concepção, utilizam os termos imediatez comunicativa ou oralidade de um lado e de outro distância comunicativa ou escrituralidade.

As manifestações verbais, fônicas ou gráficas, são definidas pelas condições de produção do texto em razão das situações comunicativas, estas entendidas como os possíveis palcos, cenas ou cenários das mensagens. Compreendem as pessoas que falam ou escrevem, os indivíduos que lêem e ouvem, o tempo e o lugar em que se passa o evento. Correspondem, pois, aos contextos situacionais e extralinguísticos, tais como define Urbano (2011a:44).

Koch e Oesterreicher (1985) não utilizam em princípio os termos língua falada e língua escrita. Para eles, a imediatez refere-se à comunicação imediata no tempo e no espaço ao passo que a distância compreende a comunicação à distância, dependente do momento e do lugar de sua produção. É o que Marcuschi (2004), em certas situações, considera por envolvimento e distanciamento.

Partindo desse pressuposto, Urbano (2011a) defende que a oralidade é o discurso falado, segundo condições, propriedades, parâmetros e propósitos específicos. É a língua da imediatez, tal como define Oesterreicher (1985) ou, 
simplesmente oralidade, abstração feita do seu canal ou meio sonoro, que deve incluir o gestual, quando a veiculação for pelo canal sonoro.

A oralidade faz paralelismo e contraponto com escrituralidade, entendida como o discurso escrito, ou seja, o discurso concebido, organizado, elaborado e produzido como texto escrito de acordo com propriedades, parâmetros e propósitos específicos. É a língua da distância, ou simplesmente escrituralidade, segundo Oesterreicher (1985). É possível a ocorrência tanto de textos orais com fortes características concepcionais de escrituralidade, quanto de textos gráficos com fortes características de oralidade. Este é o caso, por exemplo, do texto teatral.

Em sintonia com a Análise da Conversação, pode-se afirmar que a conversação é uma prática social na qual os indivíduos interagem e pela qual procuram atingir seus objetivos conversando. Ela viabiliza o trabalho cooperativo e efetiva as relações sociais e, sendo assim, não basta apenas considerar o meio e a concepção em uma análise conversacional. Todo o entorno conversacional deve ser considerado em uma interação, principalmente os elementos que a complementam, tais como as expressões corporais e fatos prosódicos como as pausas, o ritmo e a interrupção.

$\mathrm{Na}$ representação do diálogo escrito fictício, temos o apoio da pontuação (travessão, aspas, reticências) e de caracteres (itálico, maiúsculas) que mimetizam alguns aspectos da conversação real. Há, por exemplo, o uso das reticências para indicar pausas, hesitação do locutor, ritmo particular, interrupção do diálogo em relação à presença de outro interlocutor e o silêncio. O ponto final, uma pausa voluntária da parte do locutor, e os dois pontos marcam uma pausa ou uma mudança de tom. 
A pontuação é um dos principais vetores de integração do oral no escrito, a tal ponto que a ausência de pontuação destaca a rapidez das trocas verbais e a sucessão de intervenções. É por isso que as análises dos signos verbais tornam-se necessárias em um diálogo real e em um diálogo construído, isto é, os diálogos inseridos em um contexto ficcional.

$\mathrm{Na}$ linguagem falada, os parceiros encontram-se em uma comunicação face a face e pressupõem a existência de um conhecimento compartilhado entre o locutor e o interlocutor. Na linguagem oral, o receptor não é passivo e sim ativo, pois coopera na produção da mensagem. A comunicação possui caráter público e os elementos dos contextos situacionais e socioculturais precisam ser verbalizados, inclusive as pessoas e os demais elementos presentes na interação, o contexto cognoscitivo e o contexto linguístico ou cotexto. Este último é, na definição de Urbano (2011a:52-53), o texto ou os textos que precedem ou seguem o texto considerado e que pode ser responsável pela construção de sentido. O pesquisador ainda considera importante o contexto paralinguístico, ou seja, os fenômenos prosódicos ou de entonação e o contexto extralinguístico, isto é, as mímicas, os olhares, os gestos, as posturas corporais entre outros.

O gesto é um meio de expressão e de exteriorização de um conteúdo psíquico que complementa a expressão oral para o bom entendimento da mensagem durante a interação. Para o estudo do texto teatral, não podemos desconsiderar uma análise proxêmica da interação. Pavis (2008) destaca que a proxêmica estuda o modo de estruturação do espaço humano em função de oito variantes: a) a postura corporal global; b) o ângulo de orientação dos parceiros; c) a distância corporal definida pelo braço; d) o contato corporal de acordo com forma e intensidade; e) a troca de olhares, a sensação de calor; f) as percepções olfativas e 
a intensidade da voz; g) tipo de espaço, distâncias observadas entre as pessoas; h) organização do habitat, estruturação do espaço de um edifício ou de um cômodo.

Com base nos critérios de meio e concepção de Oesterreicher (1985), Urbano (2011a) define a língua falada prototípica e a língua escrita prototípica. Segundo o pesquisador (2011), a língua falada prototípica é uma atividade social verbal de produção de texto, em interação face a face. É realizada e transmitida oralmente e captada acusticamente, graças a um sistema de sons articuláveis. A língua escrita prototípica, por sua vez, é uma atividade social verbal de produção de texto, em interação abstrata não face a face. É executada graficamente pela mão e captada pelos olhos, graças a um sistema de letras articuláveis.

A língua oral é adaptável à situação, principalmente em relação à imagem do interlocutor. Basta que o ouvinte sinalize quando não compreende a mensagem para que o falante mude o modo de transmissão do tópico abordado em uma conversa.

Oesterreicher (1985) considera diversas características de textos em seu estudo, mas não trata especificamente do texto literário. Dessa forma, tomamos a teoria dele, com pequenas complementações, considerando o estilo e a época em que o texto do corpus foi escrito.

As relações entre fala e escrita são dinâmicas e devem ser consideradas dentro de um continuum de usos e de funções. Urbano (2011a:50) elabora um quadro com alguns exemplos, no qual fizemos algumas adaptações:

\begin{tabular}{|c|c|c|c|}
\hline Meio & Concepção & Denominações & Exemplificação típica \\
\hline (a) sonoro & Falada & Falado Falado & Conversa entre amigos \\
\hline (b) sonoro & Escrita & Falado Escrito & Aula de professor universitário \\
\hline (c) gráfico & Falada & Escrito Falado & Bate papo na internet \\
\hline (d) gráfico & Escrita & Escrito Escrito & Texto científico \\
\hline
\end{tabular}


Os textos situam-se em um continuum no qual podemos verificar elementos empregados tanto na língua falada quanto na escrita, sobretudo nos textos "falado escrito" e "escrito falado".

Oesterreicher (1996:331) destaca em outro estudo que, considerados como textos gráficos (meio), a tragédia clássica caracteriza-se concepcionalmente pela distância comunicativa enquanto a comédia pela imediatez comunicativa, já que podemos esperar que encontraremos elementos da língua falada em um sentido concepcional. De acordo com esse teórico alemão, o posicionamento no continuum resulta da cooperação de diversos parâmetros, tais como: relação social, número de participantes, situação espacial e temporal dos parceiros de comunicação, troca comunicativa entre os interlocutores; fixação do tema; nível de publicidade; espontaneidade e cooperação; o papel dos contextos linguísticos, situacionais e socioculturais (conhecimento compartilhado, valores e normas sociais etc.). Com base nesses parâmetros, ele formula o gráfico ${ }^{15}$ representado na página seguinte:

${ }^{15}$ O gráfico foi traduzido do alemão para o português por Raoni Caldas e, posteriormente, publicado na revista Linha d'Água no primeiro semestre de 2013. 


\section{Condições de \\ comunicação:}
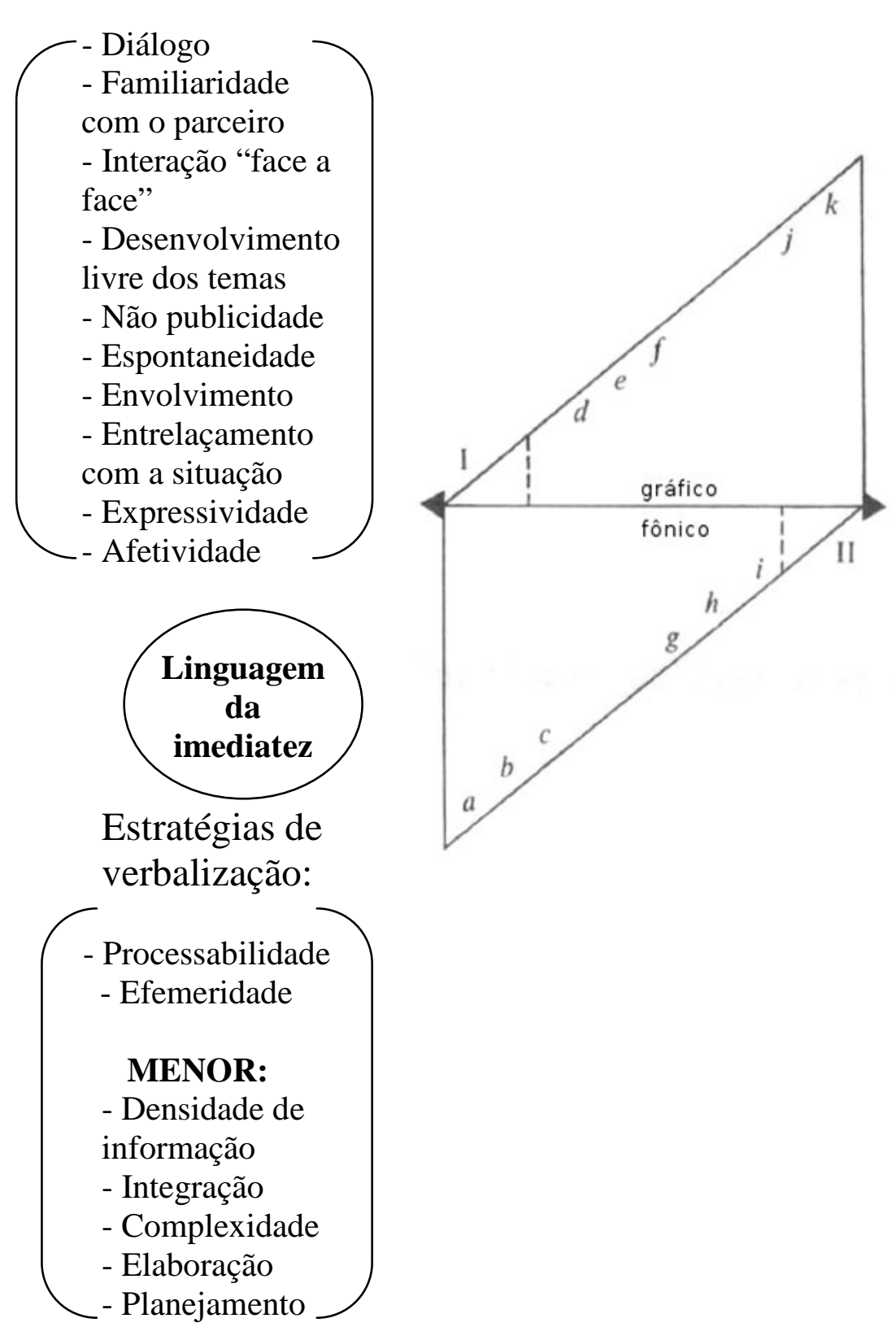

C.Descc

- Monólogo

-Desconhecimento

do parceiro

- Distanciamento espaço-temporal

- Fixação no tema

- Publicidade

- Reflexibilidade

- Destacamento-

Não entrelaçamento com a situação

- Objetividade

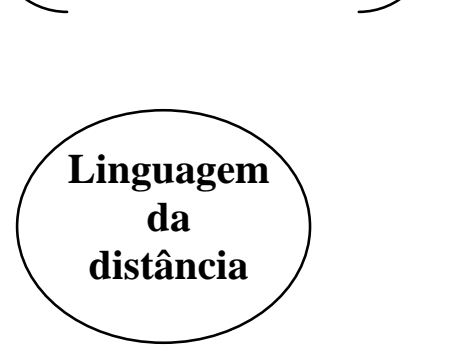

Estratégias de

verbalização:

- Processabilidade

- Reificação

- Perenidade

\section{MAIOR:}

- Densidade de informação

- Integração

- Complexidade

- Elaboração

- Planejamento

Entenda-se por $\boldsymbol{a}$ conversa casual entre amigos, $\boldsymbol{b}$ conversação telefônica com um amigo, $\boldsymbol{c}$ entrevista pública, $\boldsymbol{d}$ entrevista publicada, $\boldsymbol{e}$ depoimento em um diário pessoal, $\boldsymbol{f}$ carta privada, $\boldsymbol{g}$ apresentação pessoal (em uma entrevista de emprego), $\boldsymbol{h}$ sermão, $\boldsymbol{i}$ conferência universitária, $\boldsymbol{j}$ artigo científico e $\boldsymbol{k}$ ato jurídico (peças processuais, leis).

No gráfico, de 1985, como já salientamos anteriormente, Oesterreicher não leva em consideração o texto literário. Alguns autores, no entanto, exploram o uso 
da oralidade em suas obras, sobretudo no texto de teatro, que tem como objetivo a dramatização.

Segundo Castilho (2010:221), a língua escrita corrente e a língua escrita literária devem ser consideradas como duas grandes variedades da língua. 0 principal objetivo da primeira é manter a manutenção de contatos, a difusão de notícias, ou seja, tem fins utilitários. A segunda, por sua vez, tem finalidade artística e tende a ser mais inovadora, dependendo da época.

Em um continuum indo da oralidade para a escrituralidade, Castilho (2010: 222) formula o seguinte esquema:

\section{LÍNGUA FALADA LÍNGUA ESCRITA}

Conversa - Diálogo de peça teatral - Conferência, discurso ${ }^{16}$ - Notícia de jornal - Ensaio

A partir desse esquema, percebe-se o quanto o diálogo teatral aproxima-se de uma conversa real, uma vez que há elementos da língua falada transpostos para o domínio do discurso literário e reafirma as palavras de Ryngaert (1996:101) "o teatro é definido às vezes como um gênero em que 'se fala muito'”.

O teatro explora, em geral, as oposições existentes entre a personagem e o seu discurso, entre a fala e o contexto de sua enunciação e o público tem o estatuto de um destinatário indireto, pois é a ele que todos os discursos são dirigidos. Tratase de uma mimese da interação social e o gesto, a voz e a iluminação são capazes de modular a distância e criar efeitos de sentido.

\footnotetext{
${ }^{16}$ No esquema, a palavra "discurso" se refere à mensagem oral, geralmente solene e prolongada, que um orador profere para um público.
} 
Para entendermos a relação entre a oralidade e o texto ficcional, devemos considerar as principais características do discurso oral e do discurso literário, estudo realizado na próxima seção deste trabalho.

\subsection{O discurso literário e a oralidade}

Em um texto literário, encontramos muitas vezes uma sensibilidade no uso da língua falada para a construção dos diálogos entre as personagens. A qualidade de expressão na elaboração dos diálogos das personagens deve-se à exploração de recursos estilísticos e retóricos no texto de ficção pelo escritor, sobretudo a partir do século XIX, época em que houve uma preocupação maior com um efeito de real. Vários escritores romperam determinadas normas linguísticas até então dominantes nos séculos anteriores.

A partir da metade do século XIX, com o advento de um processo de valorização social das classes mais populares, aparecem romances nos quais há uma maior preocupação no que diz respeito à linguagem das personagens. Recriam-se, assim, formas de expressão de uma comunidade linguística, incluindo as variações orais e coloquiais em suas obras. Embora a literatura tenha certas limitações em refletir com fidelidade a língua falada, se comparada com circunstâncias reais de comunicação, é importante salientar que, antes do aparecimento de diversos sistemas de gravação e de reprodução de sons, a literatura cumpria, e ainda cumpre (mesmo que não seja de maneira exclusiva), um papel inegável de conservação de algumas maneiras de falar.

É importante considerar o contexto histórico e a manifestação literária, uma vez que as personagens evoluem em relação ao uso da linguagem e da época. A 
partir desses pressupostos, a literatura converte-se em documento histórico para o estudo da evolução da língua e das variações linguísticas. As comédias de Martins Pena é um bom exemplo neste sentido. A representação da língua oral foi muito utilizada em sua obra, o que o torna uma possível fonte para estudos da evolução da língua portuguesa do Brasil durante o século XIX. De acordo com Heliodora (2000:10):

Ainda há muito trabalho a ser feito em torno da obra de Martins Pena; apesar de todos os seus méritos, a edição de Darcy Damasceno não inclui um glossário de termos que eram de uso comum no século XIX mas que hoje já não integram o vocabulário brasileiro, em alguns casos desaparecendo, em outros mudando radicalmente de sentido. É claro que podemos sugerir que o leitor procure um dicionário, ou coisa assim, mas um glossário junto ao texto, ao lado de comentários que esclareçam usos e costumes da época que condicionam determinados aspectos da nação poderiam [sic] ajudar a popularizar a obra.

Existem recursos para que o escritor transponha a língua falada para o texto literário, permitindo que a língua falada gere o efeito de realidade a partir das adequações feitas, porque necessárias. Isso não significa dizer que a personagem é uma cópia exata de uma pessoa, mas deve ser criada pelo escritor de forma coerente com o contexto da história. Em relação ao texto teatral, muitas informações a respeito das personagens podem ser dadas quer pelas palavras dos diálogos, quer pelas ações propriamente ditas.

A linguagem literária é organizada a partir de uma intenção literária de acordo com Lefebve (1975). É a expressão humana no seu conjunto e sob todas as suas formas e se dirige a todos os indivíduos. O discurso cotidiano, por sua vez, depende sempre de um referente bem determinado, sem o qual deixaria muitas vezes de ser inteligível. Tendo como objeto de estudo o romance em prosa, Lefebve (1975:170) sustenta: 
[...] a narrativa (e em particular o romance) parece repousar sobre um paradoxo: quer-se "realista" por essência, aspirando ao papel de espelho do mundo, restituindo-nos o seu tempo e o seu espaço, os seus problemas morais, sociais, políticos. [...] Contudo, sabemos também que esse mundo é fictício, e que é sobre esta diferença que se implanta o seu poder literário e poético.[...]

Não é de hoje que a língua falada no âmbito literário mobiliza vários pesquisadores. Para designar uma conversação literária, Claire Blanche-Benveniste (2000), por exemplo, utiliza o termo francês "parlé écrit" (falado escrito). Para a pesquisadora francesa, embora possa ser considerado como não sendo uma boa fonte do que seria a língua falada, uma vez que não é espontânea e de que se trata de uma imitação do oral, a literatura pode fornecer elementos para os estudos da língua falada no que se refere ao estilo e à composição das personagens. Genette (1972) foi um dos primeiros estudiosos na França a atenuar a concepção de que o diálogo romanesco seria uma forma mimética perfeita, mas isso não impede que numerosos estudos sobre os diálogos romanescos sejam fundamentalmente orientados para uma problemática da verossimilhança.

A primeira diferença entre um diálogo oral real e um diálogo escrito fictício diz respeito ao uso de elementos da fala, como a prosódia, os sotaques, a entonação e os elementos não linguísticos, tais como os gestos e tudo o que se situa no contexto situacional. Em um diálogo real, os elementos linguísticos e não linguísticos aparecem associados e simultaneamente. No diálogo romanesco, por sua vez, tudo é transformado em universo linguístico, a fala e os elementos não linguísticos, inclusive a prosódia com o uso da pontuação.

Para que um diálogo real seja imitado no diálogo de ficção, o escritor reproduz as características do tom, do modo de enunciação, da qualidade da voz, dos gestos, dos movimentos e de alguns parâmetros situacionais por meio da figura 
do narrador. No texto teatral escrito, contamos com as indicações das didascálias para nos situarmos em relação aos gestos e ao contexto situacional. No momento em que a peça teatral é encenada, o contexto situacional nos é mostrado com a cenografia e muitas vezes a fala sofre modificações em relação às falas originais.

Outro estudioso do teatro, Ryngaert (1996:103), considera que "a fala de uma personagem organiza sua relação com o mundo no uso que ela faz da linguagem" e distingue dois casos importantes, a saber: 1) a fala como ação, ou seja, o próprio fato de falar constitui a ação da peça; 2) a fala é instrumento da ação, ou seja, ela desencadeia ou comenta a ação. Citando Ezra Pound ${ }^{17}$, Ryngaert (1996) sustenta que, primeiramente, podemos estudar o diálogo de teatro como uma troca conversacional entre enunciadores, de forma a compreender as relações entre as palavras e aqueles que as dizem e, analisar por que as dizem. Posteriormente, a análise das situações de comunicação e das relações de força entre os enunciadores nos ajudam a construir estes últimos como personagens.

Em relação à prosa, a narração vem colaborar com e englobar o diálogo verbal propriamente dito. No teatro, é o diálogo e a interação entre as personagens que conduzem à ação. Na comunicação escrita, literária ou não, os elementos contextuais, não verbais precisam ser verbalizados.

O diálogo literário caracteriza-se, então, como um diálogo escrito, idealizado de uma maneira que sistematiza o falado. O diálogo fictício não deixa de ser uma forma literária da conversação de modo que a literatura pode constituir um ramo privilegiado de observação de mecanismos da conversação comum.

Segundo Preti (1998), o emprego de recursos da oralidade na literatura pode ser uma estratégia intencional do escritor para dar a seu diálogo de ficção uma

${ }^{17}$ Ezra Pound foi um poeta e crítico literário americano, uma das principais figuras da poesia modernista no início do século XX. 
proximidade maior com a realidade. Desse modo, é possível oferecer ao leitor a ilusão de uma realidade oral, desde que tal atitude decorra de um cuidadoso processo de elaboração da escrita, privilégio do texto literário. O escritor emprega, na escrita, então, marcas de oralidade, que permitem ao leitor reconhecer no texto uma realidade linguística ao qual está acostumado em sua vida cotidiana.

\subsection{A enunciação no texto de teatro}

De acordo com Urbano (2000), a obra de ficção é como um grande e complexo enunciado, resultado de uma complexa enunciação. Entendemos, neste trabalho, que a enunciação é "o ato de produção do discurso, é uma instância pressuposta pelo enunciado (produto da enunciação)" nas palavras de Fiorin (2006: 55). Estamos cientes da polissemia do termo "discurso" empregado sob diferentes acepções. Discorremos sobre algumas definições de discurso e selecionamos, ao final, aquela a qual utilizamos nesse trabalho.

Para Ducrot (apud Flores et al. 2009), o discurso é a realização do texto. Ele propõe que os enunciados devem se apoiar uns nos outros de forma coerente para que constitua um discurso. Quando o pesquisador desenvolve a Teoria dos Blocos Semânticos, ele sustenta que o discurso designa o próprio encadeamento argumentativo e o sentido das palavras é dele dependente.

Bakhtin (2009) concebe o discurso como um fenômeno social complexo, multifacetado, que nasce a partir do diálogo entre discursos diversos. Todo discurso responde, assim, a outros dizeres, ou seja, há uma diversidade de vozes.

Émile Benveniste (1988), por sua vez, entende que o discurso é a atualização da língua cada vez que alguém assume o lugar de eu, é a linguagem posta em ação, 
é a língua assumida pelo falante, sinônimo de fala. Para estes teóricos, então, o termo discurso designa todo enunciado superior à frase.

Neste trabalho, entendemos que o discurso é um conceito idealizado a partir de uma dupla perspectiva, primeiro enunciativa e depois material, o espaço e o tempo da enunciação. Para compreendermos o significado de discurso no texto teatral, utilizamos os estudos conduzidos Issacharoff em Le spectacle du discours (1985). O autor salienta que é necessário entender o que singulariza o uso teatral da linguagem, a partir de enunciados (sua dimensão verbal) até a dimensão não verbal (sua dimensão visual, ou seja, gestos, mímicas, movimentos, roupas, corpos, acessórios, cenários). No teatro, o discurso é literalmente posto em cena.

Dessa maneira, assumimos como discurso toda manifestação concreta da atividade da linguagem (verbal e não verbal), realizada em situações e contextos diversos. Ao inserirmos o discurso em situações e contextos concretos, encontramonos no campo da pragmática, fundamental para um estudo mais detalhado nesta pesquisa.

A pragmática considera essencialmente as situações nas quais os discursos aparecem, as intenções que regem a sua produção e os efeitos que os discursos provocam. Segundo Oesterreicher (1997), os interlocutores se situam em campos dêiticos pessoais, locais e temporais. Além disso, utilizam diversos tipos de contextos e encontram-se em determinadas situações sociais e relações emocionais. A partir desse esboço da comunicação verbal, o mesmo autor elenca as condições universais de comunicação, valendo-se dos seguintes parâmetros:

1) Grau de privacidade ou do caráter público do discurso - definido pelo número de interlocutores (por exemplo, um diálogo versus uma comunicação de massas) e a 
existência de um público e de seu tipo (por exemplo, uma mesa redonda versus um discurso de televisão).

2) Grau de intimidade dos interlocutores - a existência de intimidade ou desconhecimento entre os interlocutores depende da experiência comunicativa anterior e do conhecimento mútuo.

3) Grau de emotividade e participação emocional dos interlocutores - a participação emocional pode referir-se ao interlocutor ou ao objeto de comunicação.

4) Grau de inserção ou implantação da enunciação no contexto situacional e de atuação.

5) Tipo de referência - definido pelo grau de proximidade ou distância das pessoas ou objetos mencionados no discurso, sempre em relação ao eu - aqui - agora do locutor.

6) Posição local e temporal dos interlocutores especificando o tipo de contato nesse parâmetro, diferencia-se a situação face a face de todos os tipos e graus de separação local e/ou temporal na produção e na recepção de discursos (conversação em um bar, chamada telefônica, carta, etc.)

7) Grau de cooperação - papel que o receptor exerce na produção de enunciados não somente na cooperação verbal (perguntas, propostas, correções), mas também nos graus de atenção e reação, manifestados por meio de olhares, expressões mímicas, posições do corpo etc. É necessário, aqui, distinguir a cooperação e dialogicidade. A dialogicidade se define pela possibilidade e frequência com o que os interlocutores assumem espontaneamente o papel do locutor. Se compararmos uma conversação entre amigos com a leitura de uma sentença em um tribunal, verificamos que, no primeiro caso, a comunicação é simétrica e dialogada, enquanto a segunda é assimétrica e monologada. 
8) Grau de espontaneidade da comunicação - nível de liberdade de participação e de comportamento entre os falantes. Trata-se, ainda, do maior ou menor grau de formalidade.

9) Grau de fixação e determinação do tema

Além dessas condições universais de comunicação, temos que considerar o contexto situacional na interação. Nenhum discurso surge sem ser emitido dentro de um contexto de forma que os textos veiculam vários pontos de vista, tal como sustentava Bakhtin (2009).

O texto teatral caracteriza-se, sobretudo, pela sua polifonia ${ }^{18}$. Há várias maneiras de se emitir uma mensagem ao público, seja pela voz ${ }^{19}$, seja pelos gestos corporais.

Para Pavis (2008:103), o discurso teatral distingue-se do literário ou "cotidiano" por sua força performática de levar a cabo uma ação e de ser o lugar da inscrição da representação virtual. O discurso teatral é instável, uma vez que o ator e o diretor têm a liberdade de distanciar-se do texto. Nesse sentido, Issacharoff (1985:11), com base em Émile Benveniste (1966), entende que

[...] o texto teatral não é um discurso oral, propriamente falando, é evidente: é uma forma escrita convencional que representa ${ }^{20} \mathrm{o}$ oral. Assim, o discurso ${ }^{21}$, segundo Benveniste, pode corresponder à "massa dos escritos que reproduzem discursos orais ou que deles empresta o contorno e os fins: correspondências, memórias, teatro, obras didáticas - em resumo, todos os gêneros nos quais alguém se dirige a alguém, se enuncia como locutor e organiza aquilo que diz na categoria da pessoa"22.

\footnotetext{
${ }^{18}$ Entendemos por "polifonia" as muitas vozes que se encontram e se fazem sob a tessitura do texto.

${ }^{19}$ Aqui, "voz" é entendida como o canal fisiológico.

${ }^{20}$ Grifo do original.

${ }^{21}$ Grifo do original.

22 [...] le texte théâtral n'est pas un discours oral, à proprement parler, est évident : c'est une forme écrite conventionnelle qui représente l'oral. Ainsi, le discours, selon Benveniste, peut correspondre à « à la masse des écrits qui reproduisent des discours oraux ou qui empruntent le tour et les fins: correspondances, mémoires, théâtre, ouvrages didactiques, bref tous les genres où quelqu'un
} 
No teatro, trata-se de uma representação do discurso do que seria uma enunciação real, ordinária. Os enunciados de uma personagem são emprestados de um autor que atribui à personagem réplicas de outra personagem virtual, cuja identidade efetiva não é estável. O diálogo teatral toma lugar num dispositivo comunicacional complexo, em que se sobrepõem instâncias e níveis enunciativos, o que influi no seu funcionamento.

Para situar o discurso teatral em seu espaço físico, podemos considerá-lo de forma concreta: temos o palco dividindo o espaço do público, os enunciados do palco relacionam-se com os atores que, por sua vez, tomam emprestada a palavra do autor da peça teatral. Em seguida, podemos situar o discurso de maneira referencial: o contexto espaço-temporal de tal representação.

A cena teatral, lugar da enunciação fictícia, situa toda a enunciação sob o conceito do discurso falso, concebido para escutar, mas não idealizado para agir sobre o público ou espectador na sala graças à função perlocutória ${ }^{23}$. Assim, por exemplo, quando uma personagem está prestes a assassinar outra personagem no palco, ninguém sairá de seu lugar na plateia para impedi-la e ninguém sairá da sala para chamar a polícia. No teatro, então, um diálogo é endereçado a um destinatário múltiplo: atores no palco, público na sala.

Bakhtin (2011) reconhece nos textos várias vozes falando simultaneamente, sem que uma dentre elas seja preponderante. É a partir desse princípio que ele define a polifonia. Ela é a principal característica do texto teatral.

s'adresse à quelqu'un, s'énonce comme locuteur et organise ce qu'il dit dans la catégorie de la personne " (Problèmes de linguistique générale I. Paris : Gallimard, 1966, p.242)

${ }^{23}$ Segundo Armengaud (2008), a Teoria dos Atos de Fala de J.L Austin compreende o ato locutório, isto é, o ato de pronunciar um enunciado; um ato ilocutório, que corresponde ao ato em que o locutor realiza no momento de produção do enunciado para atingir uma intenção em uma determinada condição comunicativa e um ato perlocutório, que são os efeitos produzidos por nossas sentenças em nossos interlocutores, tais como emoção, irritação e intimidação. 
Em seu estudo, Issacharoff (1985) questiona: Mas se os enunciados não provêm dos atores (eles não o escolhem), quem fala? No teatro, quem fala não é o ator e nem o diretor da peça e sim o autor. As personagens tornam-se, dessa forma, seu porta-voz. Esse canal de transmissão é ao mesmo tempo instável e imprevisível, ou seja, os porta-vozes não serão sempre os mesmos, o que faz com que nada garanta a enunciação e a elocução. O locutor é, então, o autor, por intermédio dos atores que, por sua vez, são conduzidos por um diretor.

Para compreendermos a complexidade do processo enunciativo tal como concebe Issacharoff (1985), elaboramos o seguinte esquema:

\section{Texto teatral escrito não oralizado}

\section{Autor $\longrightarrow$ interlocutor ${ }_{\mathrm{n}}$ (leitor(es))}

Em um texto teatral escrito não oralizado, temos o autor e como receptor do texto (ou interlocutor), o leitor. Aqui, caracterizamos como interlocutor ${ }_{n}$, uma vez que são $n$ interlocutores que entram em contato com a peça teatral, ou seja, vários tipos de leitores. Em seguida, enumeramos as várias instâncias comunicativas de locutores e interlocutores no texto teatral oralizado ${ }^{24}$ :

Texto teatral oralizado

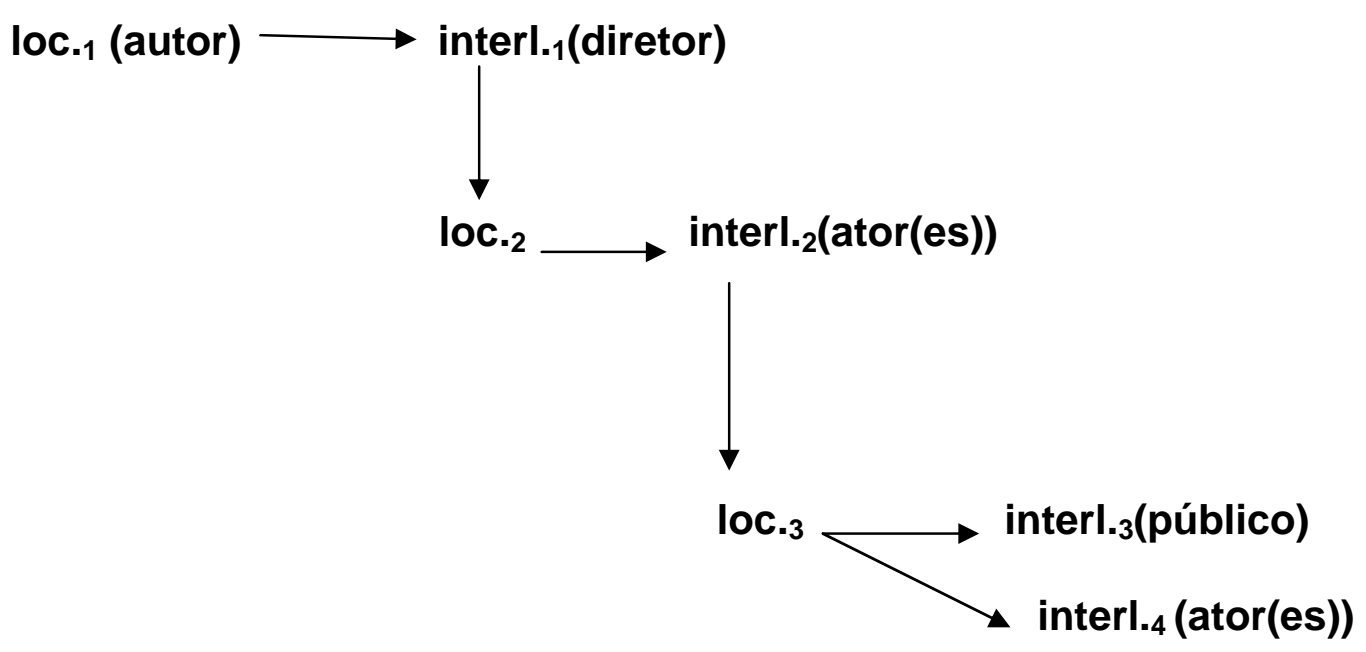

\footnotetext{
${ }^{24}$ Por questões de espaço, abreviamos o termo locutor para "loc." e o termo interlocutor para "interl." no esquema.
} 
Primeiramente, o locutor ${ }_{1}$ (o autor que escreve a obra) comunica-se com um diretor (o interlocutor 1 ), que lê a peça e pensa na encenação da peça. O diretor, por sua vez, é um meio de divulgação da obra para os atores que devem encená-la, nomeados aqui de interlocutor 2 . Os atores, que eram interlocutores 2 , transformam-se em locutores ${ }_{3}$, que repassam o texto oralizado para o público, interlocutor ${ }_{3}$, e para os outros atores, interlocutor 4.

Kerbrat-Orecchioni (1984) também destaca a polifonia no texto teatral e elabora um esquema - representado a seguir - para a cadeia de emissores/receptores:

Polo de emissão

Polo de recepção

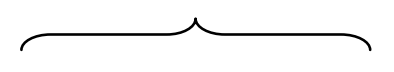

Autor/personagem/ator

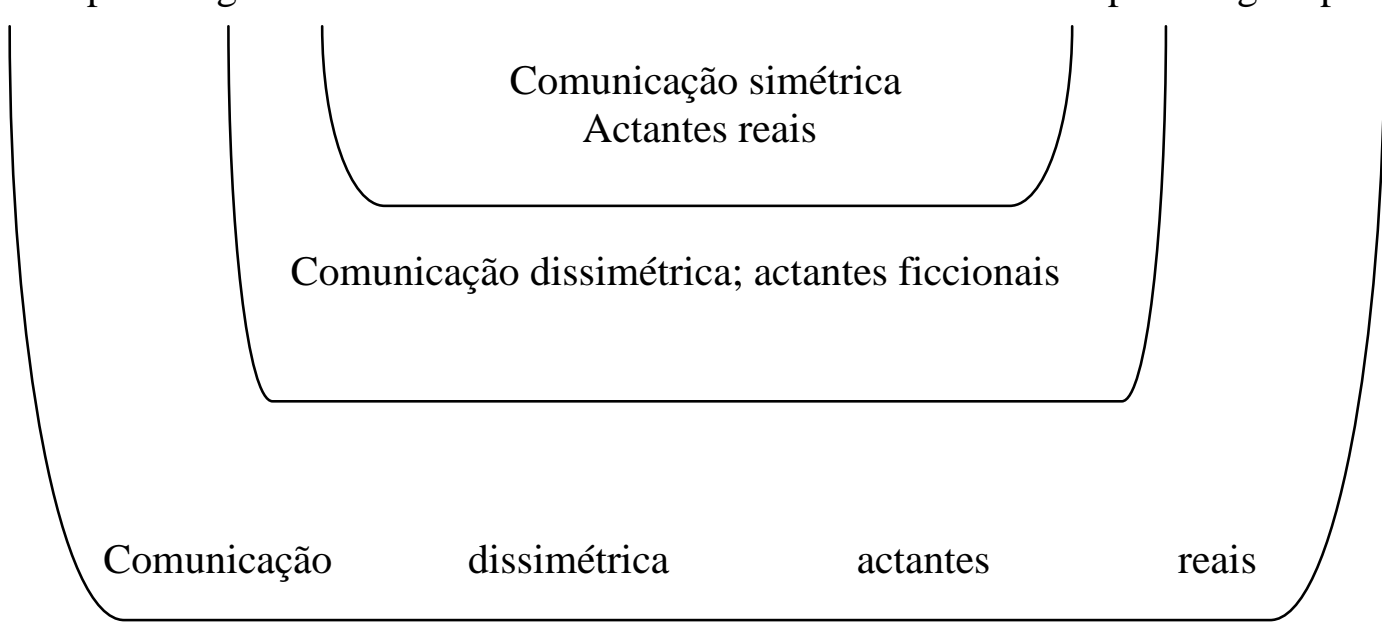

N.B: A autora entende por "actante" todo indivíduo que se encontra implicado no circuito comunicacional.

Para Kerbrat-Orecchioni (1984), a única instância conversacional pertinente é aquela das personagens, tendo em vista que é em relação às personagens que funcionam os dêiticos, por exemplo. O teatro faz dialogar as personagens que constituem o equivalente e o espelho das pessoas que, na vida cotidiana, entram em interação. 
A teórica também questiona: como receptor do texto teatral, qual estatuto recebe o público? Para responder a essa questão, ela lembra-nos que, em todo tipo de interação, podemos distinguir três categorias de receptores:

1) Destinatário direto, aquele que o emissor considera explicitamente, que testemunha certos índices de alocução de natureza verbal e paraverbal, como seu parceiro na interação.

2) Destinatário indireto, aquele que funciona como uma testemunha da troca verbal, e cuja presença é conhecida pelo emissor da troca verbal, sem ele ser verdadeiramente integrado à relação de alocução, daí seu papel de testemunha dessa troca verbal, e

3) Um receptor adicional se a presença no circuito comunicacional foge totalmente à consciência do emissor.

Em relação a esta tricotomia, o público tem o seguinte estatuto para KerbratOrecchioni (1984):

I) É um destinatário indireto tanto para o autor quanto para o ator;

II) Para a personagem, no entanto, é um receptor adicional: um intruso, um voyeur, um espectador que "surpreende" indiscretamente as conversas às quais ele não pertence.

Para Issacharoff (1985), os atos de fala (a enunciação) do discurso literário ou não literário estão subordinados aos dados textuais anteriores ou posteriores. A partir de uma série de significantes, o enunciado do texto literário transforma-se em enunciação na dramatização, transmutando-se, assim, em um ato de fala. Isso implica a presença de um locutor, de um interlocutor e de um contexto espaçotemporal específico. Segundo Ryngaert (1996: 110): 
[...] Em outros termos, mesmo o teatro não sendo conversação, é importante para muitos autores buscar nela seus materiais sem filtrálos nem edulcorá-los em demasia, mas antes "combiná-los". [...] Claro que o teatro não registra todas as vicissitudes da fala viva proferida por sujeitos ativamente envolvidos na conversação, mas ele encontra nesta seu alimento.

É importante salientar que essa observação do autor diz respeito à criação de textos teatrais escritos e não em relação ao texto oralizado no palco. Issacharoff (1985) sustenta que a referência no teatro é de dois tipos: intratextual, isto é, orientada no universo fictício (do texto literário) ou extratextual, nesse caso, orientada fora do contexto textual.

Quanto à representação do referente, quatro possibilidades estão disponíveis ao dramaturgo: a primeira seria não visível (exclusivamente verbalizada); a segunda parcialmente visível (figuração de um conjunto não mostrado integralmente); a terceira visível (visualizada somente) e a quarta representação seria visível e referida no diálogo. O espaço (o perceptível) depende da referência. Há, desse modo, duas possibilidades: dependência integral, se os objetos, móveis, decoração, não são mostrados no palco. Nesse caso, os elementos do cenário são somente uma existência verbal; dependência parcial, se estes elementos são visualizados. Nesse caso, a referência do diálogo suscita a atenção dos espectadores.

Para Ubersfeld (1977:12), o cenário também exerce um papel importante no processo enunciativo, pois seria também um emissor:

Tudo se passa como se todo discurso teatral se inscrevesse em um duplo sistema de signos: a) os signos (linguísticos) do discurso propriamente dito; b) os signos emitidos pelo cenário; poderíamos dizer (se não fosse difícil fazer uma teoria de tal afirmação) que todo discurso teatral tem um duplo emissor: a personagem e o espaço cênico ${ }^{25}$.

\footnotetext{
25 Tradução livre do texto original francês : «Tout se passe comme si tout discours théâtral s'inscrivait dans un double système de signes : a) les signes (linguistiques) du discours proprement dit ; b) les signes émis par le lieu-décor; à la limite on pourrait dire (s'il n'était pas difficile de faire la théorie
} 
Neste sentido, consideramos que o cenário pode indicar um conflito futuro na história, por exemplo. O uso de recursos como uma simulação de tempestade costuma sugerir uma tensão, por exemplo. Colabora também, portanto, com um processo enunciativo, complementar à fala da personagem e à ação.

A enunciação literária não pode ser considerada como uma troca linguística comum, uma vez que exclui o caráter imediato de uma conversação. Sob essa perspectiva, em comum, o leitor de um romance, de um poema e o espectador de uma peça de teatro não têm contato com o autor. Neste sentido, o texto literário aparece como uma "pseudo-enunciação", nas palavras de Maingueneau (1990:10).

Essa especificidade do texto literário afeta, particularmente, a noção de situação de enunciação, em suas três dimensões: pessoal, espacial e temporal.

No teatro, a situação de enunciação é determinada pelas indicações cênicas, ou seja, as didascálias. Elas descrevem o local e as circunstâncias da produção de um ato de enunciação tanto na leitura de um texto dramático quanto em sua encenação, segundo Pavis (2008:361).

Enquanto um enunciado comum remete diretamente a um contexto físico perceptível, os textos literários constroem cenas enunciativas por meio de um jogo de relações internas no próprio texto. O narrador de ficção é um ser textual, pois as características são definidas somente pela narrativa. No teatro, por outro lado, dizer é fazer, pois a palavra dramática é posta em serviço da ação por meio da linguagem. A linguagem tem como função desenvolver o caráter das personagens dentro da peça e, sobretudo, um meio de interação na sociedade, mesmo que fictícia. A linguagem exerce um papel fundamental na construção de um status para a personagem.

d'une telle affirmation) que tout discours théâtral a un double émetteur : le personnage et l'espace scénique ». 


\section{CAPÍTULO 4: STATUS E LINGUAGEM NA INTERAÇÃO}

\subsection{A linguagem na construção de um status}

A interação social depende da situação comunicativa em que se processa e implica a construção simultânea da própria interação e dos papéis sociais que os interlocutores exercem ou não. Para estudar as interações sociais, recorremos tanto à Sociologia, quanto à área da linguagem propriamente dita, especialmente a Análise da Conversação.

A língua é um meio de interação entre o indivíduo e a sociedade. De acordo com Gumperz (1989:14), a identidade social e a etnicidade são em grande parte produzidas e reproduzidas pela linguagem. Considerando os aspectos pragmáticos, a Análise da Conversação pode levar em consideração os diferentes pressupostos culturais a respeito da situação e do comportamento apropriado e das intenções que estão aí associadas. Além disso, ainda existem as diferentes maneiras de estruturar uma informação ou um argumento na conversação e as diferentes maneiras de falar, com o uso de convenções linguísticas inconscientes (o tom de voz - agudo ou grave, por exemplo) para enfatizar algum termo no processo comunicativo. Por maneiras de falar, o autor considera a gramática, o léxico, a prosódia, as pausas e as expressões idiomáticas.

Para Gumperz (1989), é necessário estabelecer uma "flexibilidade comunicativa" em uma conversação, isto é, adaptar estratégias comunicativas aos participantes do ato de fala. Um meio de observação dessa flexibilidade comunicativa ocorre no meio não verbal, pois a comunicação depende de índices comportamentais. Por sua vez, os índices de contextualização nos oferecem uma 
informação geral do quadro dos participantes no processo interacional. Os sinais extralinguísticos são ligados ao quadro e ao conhecimento dos próprios participantes antes da interação.

De acordo com Preti (2004), a linguagem pode influir na representação da "máscara" social do falante. O pesquisador sustenta que cada indivíduo possui uma posição dentro de um grupo, a qual Preti chama de status. Este pode ser atribuído em razão do sexo, da idade, da classe social, da religião etc. O status também pode ser adquirido, sobretudo pelo mérito, pela competição, pelo cargo profissional etc.

A condição de linguagem como indicadora de papéis e/ou status social também é apontada na Sociologia. Observa-se que para Robinson (1977:114), uma das funções da linguagem é a de definir relações entre papéis. Ele define papel como o conjunto de comportamentos prescritos para uma pessoa que ocupa uma posição na estrutura social e salienta que há sempre regras que governam o comportamento de uma pessoa, enquanto membro de uma categoria socialmente significativa.

A representação de um papel dentro de uma sociedade requer um esforço para projetar aos outros a imagem desejada, e a linguagem cumpre um papel importante nessa construção imagética. Isso porque a linguagem é um elemento importante ao desempenho social do indivíduo, pois, ao falarmos, refletimos o tempo em que vivemos, a região em que estamos ou de onde proviemos, revelamos nossa condição sociocultural, a profissão, o grau de escolaridade, o sexo, a faixa etária e alguns aspectos de nossa personalidade. Robinson (1977:123) acrescenta que a palavra status, em Sociologia, serve como termo técnico descritivo para designar o atributo de uma pessoa ou posição que tenha significação sociológica geral em termos de direitos e obrigações de acordo com o atributo de que o status deriva. As 
relações que envolvam direitos e deveres diferentes implicam um desequilíbrio de poder e as formas assimétricas são mais suscetíveis de ocorrer nesses casos. Esse tipo de assimetria é notado nas diferenças de status etário (crianças-adultos), status ocupacional (patrão-empregado) etc.

Ainda na Sociologia, Goffman (2005:21) defende que qualquer indivíduo possui certas características sociais que norteiam a forma como os outros o valorizam e o tratam em adequação ao que foi "mostrado". Trata-se do que o autor denomina "fachada social" para expressar o que caracteriza as pessoas, como o vestuário, sexo, idade e linguagem, expressões faciais, gestos corporais, características raciais, altura, aparência, atitude e padrões de linguagem.

Nos estudos da linguagem, Preti (2008:272) sustenta que ter um status significa cumprir uma gama de comportamentos, tais como a postura ética e os cuidados com a aparência física, o vestuário e a linguagem, o que se traduz em um papel social. Quando o indivíduo desempenha um papel social, a sociedade deve reconhecer e respeitar o indivíduo com um comportamento adequado.

É claro que aparência e maneira podem se contradizer, mas espera-se uma compatibilidade confirmadora entre aparência e maneira, ou seja, é necessário um tipo de coerência da "fachada social". Nesse sentido, podemos avaliar que existe uma estreita relação entre a "fachada social", o tempo e o espaço, uma vez que pode haver uma mudança de comportamento dependendo da época e do espaço em que se dá a conversação.

Quando uma pessoa projeta uma definição da situação e, com isso, pretende ser uma pessoa de determinado tipo, automaticamente exerce uma exigência moral sobre os outros, obrigando-os a valorizá-la e a tratá-la de acordo com o que as pessoas de seu tipo têm o direito de esperar. 
Há várias possibilidades de se identificar o status de uma pessoa, entre elas destacamos a prosódia, a postura, o vestuário, o uso do léxico e o uso das formas de tratamento, elementos inseridos em uma situação comunicativa determinada.

\subsection{A diversidade linguística}

O processo interacional revela uma série de pistas para que o interlocutor adeque o seu modo de falar a uma situação específica. É importante, pois, respeitar o "contrato" conversacional, isto é, os participantes de uma enunciação devem aceitar princípios e regras para que ocorra a troca conversacional com um registro ${ }^{26}$ adequado.

Segundo Preti (2003a), a mensagem apresenta variações de escolha de acordo com a posição do falante e do ouvinte. Vários fatores influenciam na maneira de falar, tais como o fator temporal, o fator espacial (as variedades geográficas), os fatores socioculturais e os fatores situacionais.

Em relação ao fator temporal, salienta-se que a língua portuguesa brasileira sofreu várias modificações de usos linguísticos em vários momentos históricos. Resumidamente, com base em Silva Neto (1977) e em Mattos e Silva (2011), elencamos os principais momentos:

a) de 1532 a 1654: é escasso o elemento branco, com predomínio de índios e de africanos no território brasileiro. Segundo Silva Neto (1977), é a fase do primeiro contato inter-racial.

\footnotetext{
${ }^{26}$ Entende-se por "registro" as variações determinadas pelo uso da língua pelo falante, em situações diferentes, tal como sustenta Preti (2003a:38).
} 
b) de 1654 a 1808: o elemento indígena vai desaparecendo, ao mesmo tempo que cresce a influência dos brancos e dos negros. De acordo com Silva Neto (1977:73):

[...] a fala dos senhores, o idioma oficial e literário - com o prestígio duplo de língua escrita e língua dos dominadores - irradiava-se, tomando aqui alguns aspectos próprios que, sem fugir à estrutura linguística comum que constitui o mesmo domínio linguístico, o distinguem do português europeu.

Produzia-se uma nivelação linguística, provocada pela mistura de falares metropolitanos. [...]

c) de 1808 até hoje: Em 1808, o Rio de Janeiro se transforma em capital do mundo português com a chegada do Príncipe Regente. De acordo com Silva Neto (1977), as grandes famílias do campo emigram para as cidades. Isso trouxe uma rápida e profunda urbanização com reflexos na língua portuguesa brasileira. Ao longo do período colonial e pós-colonial, a população de ascendência africana foi majoritária e influenciou a língua portuguesa do Brasil, assim como a vinda de imigrantes.

Como já mencionamos, não é só o aspecto temporal que se deve levar em consideração em uma troca conversacional. A relação de proximidade/distância entre o locutor e interlocutor, por exemplo, manifesta-se pelos temas abordados em uma conversação, assim como o registro de língua utilizado, formal ou informal.

As escolhas linguísticas podem variar de acordo com a situação comunicativa e o espaço em que ocorre. Destacam-se, neste sentido, as variedades geográficas, ou seja, a oposição entre linguagem urbana e rural. A linguagem urbana está mais próxima da linguagem comum, esta última entendida como expressões e construções mais usuais, facilmente compreendidas e aceitas dentro de uma comunidade linguística. A linguagem rural, por sua vez, costuma ser considerada mais conservadora e isolada. 
De acordo com Preti (2003a:24), as variedades geográficas

[...] ocorrem num plano horizontal da língua, na concorrência das comunidades linguísticas, sendo responsáveis pelos chamados regionalismos, provenientes de dialetos ou falares locais.

Além dos fatores já aludidos, devemos considerar também as variedades socioculturais, que ocorrem dentro da linguagem de uma comunidade específica (urbana ou rural) e que são influenciadas por fatores ligados ao falante, à situação ou a ambos concomitantemente. Neste sentido, destacamos:

a)a idade - o uso do léxico é diferente de acordo com a faixa etária. Uma criança apresenta um conhecimento vocabular restrito em oposição ao adulto, por exemplo.

b) o sexo - a oposição linguagem homem/mulher determina escolhas lexicais devido a certos tabus morais. É menos frequente, por exemplo, o uso de palavras de baixo calão por parte das mulheres.

c) a profissão - a profissão pode determinar escolhas lexicais condizentes com a atividade realizada. Geralmente, emprega-se uma linguagem técnica ou profissional, principalmente em profissões ligadas à medicina e à área jurídica. Segundo Preti (2003a), a linguagem técnica é empregada para nomear atividades específicas ou utilizada como recurso expressivo para uma comunicação mais eficiente conforme as conveniências sociais. Decorre do prestígio social que certas profissões alcançam e assim, o vocabulário técnico adquire prestígio social.

d) a posição social - o status do falante exige um cuidado maior em termos de uso da linguagem.

e) o grau de escolaridade - dependendo do falante, o grau de escolaridade determina a escolha adequada da linguagem de acordo com a situação comunicativa. 
f) o local de residência - em geral, o local pode influenciar no vocabulário e na pronúncia.

A diversidade linguística, no entanto, pode sofrer uma ação repressiva, constituída pela norma da comunidade linguística em que a troca conversacional ocorre.

A partir desse pressuposto, discutimos nesse segmento a noção de norma, registro culto, registro popular, registro formal e informal. Neste estudo, apresentamos, principalmente, dois pontos de vista, o de Preti (2003a) e o de Urbano (2011a).

Antes de tratarmos propriamente do sentido de norma para Urbano (2011a), asseguramos que o conceito de norma é objeto de estudo de vários pesquisadores. De acordo com Leite (2002:19), a norma é a tradição a que todos obedecem e a que são submetidos, ocorrendo nos grupos sociais:

A norma é resultado do uso linguístico de um dado segmento social e esse uso, por tradicional, é preservado e varia de acordo com as possibilidades de realização que o usuário faz da língua. Então, um falante que tem conhecimento da prescrição linguística, naturalmente, alinhará sua linguagem o quanto possível a ela, a depender da situação de comunicação.

Neste sentido, Urbano (2011a:35-36) considera a norma em duas acepções:

(1) regra que determina como alguma coisa deve ser feita, o que corresponde, em questão de gramática, à chamada gramática tradicional. É a norma prescritiva, que implica avaliação e correção, de que decorre o adjetivo normativo ${ }^{27}$;

(2) estado habitual, o que é de uso corrente, de que decorre o adjetivo norma ${ }^{28}$, o qual diz respeito à determinação e à descrição de uma normalidade, de um fato corrente e geral e, por isso, está relacionado ao uso.

\footnotetext{
${ }^{27}$ Grifo do original.

${ }^{28}$ Grifo do original.
} 
A norma considerada padrão é uma criação social e institucional. É uma concepção de grupos sociais que, em um dado momento, decidiram escolher, entre diferentes usos, o modo mais "correto" da língua e que, em seguida, encontraram meios de impor este e rejeitar outros usos. Do ponto de vista descritivo, diferentes normas de realização de uma mesma língua coexistem. O falar dos roceiros, por exemplo, pode não obedecer às mesmas normas linguísticas da língua padrão.

A variação linguística não assegura necessariamente uma avaliação normativa. Diferentes formas de dizer podem ser aceitas pela norma sem que isto se torne suscetível de sanção. Entretanto, uma variação pode ser um objeto de "classificação social" e algumas realizações da língua podem ser qualificadas de "corretas", "erradas", "populares" e "vulgares". A situação de comunicação exerce um papel fundamental na conversação, uma vez que é por meio dela que os locutores e interlocutores escolhem usos linguísticos adequados a cada situação. Em relação ao diálogo literário, Preti afirma (2004:183):

Uma situação de comunicação apresentada pelo diálogo literário
poderá ser a reprodução natural (tanto quanto possível, porque ficam
praticamente ausentes as marcas prosódicas, limitadas que são às
informações da voz narrativa) de um ato de fala, desde que se
considerem os papéis sociais dos interlocutores e as variações
linguísticas necessárias para representar o seu status.

Há uma norma que parece estar numa posição hierárquica superior às outras: a norma culta. Para Preti (2003a), a linguagem culta ou padrão tem maior prestígio e se usa em situações de maior formalidade, pois representa um pressuposto de ideal linguístico de uma comunidade. Ela se prende às regras da chamada gramática normativa. É a norma que regula a linguagem falada e a linguagem escrita das pessoas cultas e é normalmente ensinada na escola. Urbano (2011a) usa o termo linguagem cuidada ou culta para a linguagem que comporta as subvariedades de um 
patamar de maior elaboração e formalidade. Em relação à norma culta, Urbano (2011a) leva em consideração três dimensões, a saber:

1) A norma culta objetiva - expressa o uso concreto. É também denominada de "norma explícita" ou "padrão real";

2) A norma culta subjetiva - representa a atitude que o falante assume diante da norma culta objetiva. É também denominada de "norma implícita" ou "padrão ideal"; e

3) A norma prescritiva - resultado da associação da norma objetiva e da norma subjetiva, são regras estabelecidas e ensinadas na escola.

Para Preti (2003a), a linguagem popular ou subpadrão, por sua vez, tem menor prestígio e é usada em situações de menor formalidade. Ela é mais aberta às transformações da linguagem oral do povo. Urbano (2011a) entende por linguagem popular aquela que comporta subvariedades de um patamar de informalidade e espontaneidade. O referido pesquisador (2011a:29) usa o termo popular em dois sentidos: em um sentido restrito, em oposição a culto; segundo num sentido amplo, sinônimo de "do povo ou do próprio povo". O primeiro sentido diz respeito à linguagem inculta ou uso corrompido. Registra frequentes desvios gramaticais, vocabulário incorreto, gírias, termos obscenos, articulações fonéticas deficientes ou displicentes. O segundo sentido, mais amplo, refere-se à língua que o povo fala, é a linguagem do cotidiano, despreocupada, distensa, empregada inclusive por letrados quando se encontram em situações desse tipo. O autor entende "povo" como a soma de todas as camadas socioeconômico-culturais em suas diversas circunstâncias.

Apesar de o uso da linguagem configurar o status do falante, ao mesmo tempo o uso é flexível, uma vez que o falante tem a habilidade de adaptar o seu 
discurso de acordo com o nível de instrução de seu interlocutor e com a situação de comunicação. De acordo com Preti (2003a:37):

[os] fatores situacionais não dizem respeito diretamente ao falante, mas apenas às circunstâncias criadas pela própria ocasião, lugar e tempo em que os atos de fala se realizam, e também às relações que unem falante e ouvinte no momento do diálogo. [...] Também se atribui à situação a importância das variações do tema do diálogo, bem como os elementos emocionais que podem alterar a linguagem habitual do falante [...]

Salienta-se que o grau de intimidade entre os participantes do ato interacional também é um fator importante para a análise das variações da linguagem. Para Preti (2003a:38), as variações quanto ao uso da linguagem pelo mesmo falante em função de diferentes situações podem ser denominadas de registro formal e registro coloquial. O primeiro é empregado em situações de formalidade, com predominância da linguagem culta e o segundo é utilizado para situações familiares, com predominância da linguagem popular e de uma intimidade maior entre os participantes da interação. No âmbito desta pesquisa, no entanto, preferimos empregar o termo "registro informal" para a definição de "registro coloquial" de Preti (2003a).

Os limites entre um registro e outro são difíceis de precisar às vezes; destacam-se, sobretudo, nos termos lexicais, uma vez que esse campo sofre visivelmente os reflexos das transformações sociais.

\subsection{O léxico na construção de um status}

Uma característica muito comum em autores que tentam criar a realidade de uma personagem é o uso de um vocabulário comprometido com as peculiaridades de época, de classe social, de ambiente, entre outros em relação ao momento em 
que foi escrita a obra. As escolhas lexicais refletem o contexto de uma situação comunicativa e o papel social de um indivíduo.

Biderman (1996:32) entende que "léxico é o conjunto abstrato das unidades lexicais da língua; vocabulário é o conjunto das realizações discursivas dessas mesmas unidades." A autora (1996:27) sustenta que

o vocabulário exerce um papel crucial na veiculação do significado, que é, afinal de contas, o objeto da comunicação linguística. A informação veiculada pela mensagem faz-se, sobretudo, por meio do léxico, das palavras lexicais que integram os enunciados.

Reconhecemos que o vocabulário é fundamental para a veiculação de uma mensagem e acrescentamos, tal como Preti (2003b), que a dinâmica de uma sociedade é expressa nas transformações do léxico. Como já mencionamos, acreditamos que as escolhas lexicais são fundamentais para a cultura de uma sociedade ou para a configuração de grupos sociais, mas devem ser consideradas juntamente com o contexto situacional. Neste sentido, Hilgert (2003:72) afirma que

[...] tratar da seleção lexical na construção de um texto implica também focalizar a construção do sentido no texto e do texto. E a produção do sentido, para a qual a seleção lexical concorre, identifica-se com o próprio ato da enunciação. O enunciador, em seu fazer enunciativo, faz escolhas lexicais para produzir os sentidos que viabilizem os seus propósitos em relação ao enunciatário, na interação em desenvolvimento.

Émile Benveniste (2006) acredita que a relação língua/sociedade é mais evidente no léxico, observado o nível linguístico. Benveniste (2006:100) defende que

O vocabulário conserva testemunhos insubstituíveis sobre as formas e as fases da organização social, sobre os regimes políticos, sobre os modos de produção que foram sucessiva ou simultaneamente empregados, etc. 
Os diferentes locutores de uma mesma comunidade linguística não utilizam os mesmos usos linguísticos e as mesmas escolhas lexicais, pois as línguas manifestam variação e mudança a todo instante.

Os fatores extralinguísticos responsáveis pela variação são numerosos e de importância variada, tais como o regional, o social, o estilístico e o temporal.

Esses fatores não devem ser desconsiderados nos textos de ficção, uma vez que uma maneira de se marcarem as personagens socialmente se dá por meio do léxico. Para Bally (1951), a linguagem não é somente um fato psicológico, mas um fato social. Para ele a linguagem é uma expressão de um pensamento comunicado a outro ou expresso para a representação do outro e classifica, de uma maneira ou de outra, o falante individual e socialmente. Essa classificação tem um caráter moral, aparentemente.

Dessa forma, diferentes usos linguísticos e diferentes escolhas lexicais podem ser afetados pela estruturação social: por exemplo, espera-se um empresário não falará como um operário, um universitário não falará como um analfabeto. Há usos linguísticos e escolhas lexicais que os indivíduos reconhecem como mais valorizados e outros julgados como estigmatizados. Nesse sentido, essa variação diferencia a sociedade em função de uma hierarquia social.

Além das escolhas lexicais e dos aspectos linguísticos mencionados até então, as formas de tratamento também organizam a sociedade em papéis sociais, já que geralmente revelam uma hierarquia social. 


\subsection{As formas de tratamento}

Kerbrat-Orecchioni (1990) entende que as formas de tratamento são o conjunto de expressões que o locutor dispõe para designar seu interlocutor. Salienta, ainda, que essas expressões têm, geralmente, um valor dêitico e servem para estabelecer um tipo particular de elo social. As formas de tratamento englobam os pronomes pessoais e as formas nominais. Robinson (1977) acredita que as formas de tratamento são um componente de um sistema de comunicação cuja eficiência depende de convenção e é necessário que tais convenções sejam geralmente conhecidas na cultura daqueles que estão envolvidos no discurso.

No âmbito desta pesquisa, entendemos que as formas de tratamento são "palavras ou sintagmas que o usuário da língua emprega para se dirigir e/ou se referir à outra pessoa", tal como define Silva (2003:170).

O uso de diferentes formas de tratamento não é indiferente e implica múltiplas relações entre os vários status sociais e os consequentes papéis para desempenhálos.

Para a análise do corpus, consideramos duas possibilidades de empregar as formas de tratamento: um tratamento direto - como os locutores e os interlocutores presentes na cena teatral dirigem-se uns aos outros durante a interação e um tratamento indireto - como os locutores mencionam ou tratam indiretamente os interlocutores que não participam do ato interacional no momento da fala, presentes ou não na cena.

Para Kerbrat-Orecchioni (2006:63), os locutores e interlocutores podem se mostrar mais ou menos "próximos" ou "distantes" no decorrer de uma interação e as formas de tratamento são uma das possibilidades desse tipo de indicação que pode variar no decurso da conversa. 
Entendemos o termo "distância", em consonância com Kerbrat-Orecchioni (2006), como metáfora espacial, "guardar suas distâncias", "ser/estar distante", "ser/estar próximo de alguém", espacial ou emocionalmente. Trata-se de um eixo gradual orientado, de um lado, para a distância; e, de outro, para a familiaridade e para a intimidade.

Kerbrat-Orecchioni (1990:35) sustenta que há um sistema de expressão da relação interpessoal organizado a partir de três dimensões gerais, a saber:

1) a relação "horizontal": eixo da distância;

2) a relação "vertical" : eixo da dominação ou de um sistema hierárquico; e

3) a relação conflitual versus consensual.

Tudo isso se relaciona a uma troca particular que depende das características externas e internas de uma interação, de acordo com os seguintes princípios, aqui resumidos, tal como sustenta a referida pesquisadora (2006:63):

1) Toda interação desenrola-se em um determinado contexto e põe em presença determinadas pessoas, com características particulares e com um tipo de laço socioafetivo;

2) Na interação, ocorrerá em um determinado número de eventos e será trocado um número de signos (verbais e não verbais);

3) Os comportamentos produzidos na interação são em grande parte determinados pela situação, mas as pressões contextuais deixam aos interlocutores uma "margem de manobra", tais como uma mudança na forma de tratamento. Assim, o tratamento geralmente é negociável, dependendo da situação.

Kerbrat-Orecchioni (1990) ainda destaca que as informações contextuais são dependentes de alguns fatores, tais como: 
a) As propriedades intrínsecas e relativas a cada participante, como o sexo, a idade e o status social. A idade, por exemplo, tem um papel decisivo na interação entre jovens e idosos;

b) A natureza da relação prévia entre os participantes da interação: grau de conhecimento, tipo de ligação (familiar, amizade, profissional, hierárquico ou não) ou parte eventual de um mesmo grupo (clã, casta, clube, partido, sindicato etc.). Em geral, por exemplo, os membros de uma mesma família usam uma forma mais informal, mesmo sendo de gerações diferentes. Se a interação é entre adultos que não pertencem à mesma família, há outros fatores como a relação cognitiva, social e afetiva e que são responsáveis pelas escolhas do tratamento adequado;

c) O tipo particular de contrato que os une durante a troca comunicativa. KerbratOrecchioni (1990) ilustra como exemplo uma situação em que um motorista de táxi abre a porta do carro para uma senhora e esta responde por um agradecimento com um "Obrigada"; e

d) A natureza do setting ${ }^{29}$, o número de participantes, o caráter mais ou menos formal da situação de interação etc.

Alguns dados não verbais podem confirmar e colaborar com a posição de um interlocutor inserido em uma sociedade. Para Kerbrat-Orecchioni (1990:55), os gestos também constituem um indicador do estado da relação em uma interação face a face. Eles são facilmente percebidos em uma conversação, porém, no texto literário, nem sempre eles são verbalizados, sobretudo em uma narrativa. No texto teatral, os gestos adquirem importância para a encenação e, por isso, sempre são verbalizados por meio das didascálias presentes no roteiro de teatro. Além disso, na

\footnotetext{
${ }^{29}$ Trata-se do espaço físico (espaço e tempo) e psicológico.
} 
representação no palco, a postura e a orientação do corpo podem evidenciar uma relação íntima ou não.

Kerbrat-Orecchioni (1990:75) ainda destaca outros elementos não verbais em uma interação, tais como:

1) aparência física - tamanho, vestimenta, acessórios;

2) dados proxêmicos - como ocupamos o espaço do outro, a orientação do corpo e do rosto;

3) comportamentos que indicam a submissão - ajoelhar-se, inclinar-se em relação ao outro etc; e

4) olhares - afronta visual, olhar tímido ou subalterno, olhar dominante, abaixar os olhos etc.

Além dos fatores listados acima, a referida pesquisadora (1990) destaca também fatores prosódicos ou vocais, tais como a intensidade vocal, a imposição da palavra por meio de um tom de voz mais alto etc. O mesmo tipo de estratificação pode ser verificado em diferentes dialetos, regionalismos, gíria e linguagem técnica. Um simples sotaque regional indica a origem dos participantes da interação, por exemplo.

Dessa forma, o uso das formas de tratamento pode ser determinado por fatores, tais como a hierarquização da sociedade, a natureza do laço socioafetivo, a natureza da situação comunicativa (informal ou formal), a idade, o sexo, a hierarquia profissional, a posição familiar; os interlocutores devem atentar um ao outro a isso para estabelecer uma interação sem conflitos, sem transgredir as normas sociais. Tal como sustenta Biderman (1972-1973:371), a estrutura social depende das relações estabelecidas entre os indivíduos. Entretanto, não só esses parâmetros 
devem ser levados em conta, mas também a aptidão ao dirigir-se e a adaptar-se a diversas situações de comunicação tornam-se essencial no processo comunicativo.

Maltz e Borker (apud Gumperz 1989), entretanto, afirmam que a participação em grupos sociais diferentes cria diferentes convenções discursivas, mesmo se os indivíduos foram criados em meio familiar idêntico ou similar.

Diversos pesquisadores estudaram também as formas de tratamento. Braun (apud Kerbrat-Orecchioni 1990) estudou as formas de tratamento com base em várias línguas junto com uma equipe da Universidade de Kiel. Adaptamos para o português a organização das formas tratamentais com base nos estudos do referido pesquisador:

1) Pronomes pessoais de segunda pessoa (e/ou desinências verbais correspondentes)

2) Antropônimos, ou nomes pessoais (nomes próprios, sobrenomes, diminutivos e apelidos.), como “Maria”, "Fabinho”, "Silva”, "Chico";

3) Termos de parentesco, como "Mãe", "Filho", "Titia" ;

4) Tratamentos do tipo "Senhor/Senhora" ;

5) Títulos de nobreza: "Duque”, "Doutor”;

6) Nomes abstratos tais como "Vossa Excelência”, "Vossa Graça” etc ;

7) Termos de profissão: "professor", "porteiro" ;

8) Termos que precisam a natureza da relação: "amigo", "vizinho" etc.;

9) Termos afetuosos, como "querido", "querida", "meu amor". ; e

10) As expressões de injúria, como "velhaco" , "canalha" , entre outros.

Entre os estudos das formas de tratamento, destacamos também o ponto de vista de Brown e Gilman (1960). Ambos conduziram os estudos das formas de tratamento a partir da relação entre a estrutura linguística e a estrutura social com 
base na polaridade poder-solidariedade, representados respectivamente pelo sistema pronominal $\mathrm{V}$ (vous, Sie, uy,usted,vois) e $\mathrm{T}(t u, d u, t y, t u, t u)$. Os pesquisadores estudaram o sistema pronominal das línguas indo-europeias que possuíam duas formas para o "you" da língua inglesa, língua materna dos pesquisadores. O poder associa-se ao uso não recíproco dos pronomes, configurando relações assimétricas. Exprimem uma diferença de status hierárquico entre os interlocutores. A solidariedade, por sua vez, caracteriza-se pelo uso recíproco dos pronomes, configurando relações simétricas.

A ideia de poder, autoridade ou dominância dá-se no decorrer da interação, quando os participantes da troca comunicativa colocam-se de forma hierárquica durante uma troca conversacional. Há, em geral, entre os participantes aqueles que ocupam uma posição de prestígio ou de distância em relação ao outro. Esse tipo de relação é assimétrica, pois há um uso não recíproco das formas de tratamento.

O uso da linguagem pode refletir certas relações de poder ou de solidariedade existentes entre os locutores e interlocutores, que confirmam, contestam e constituem os elementos da conversação.

Em relação às formas de tratamento no português europeu, Cintra (1986) realizou um importante estudo diacrônico em termos de uso das formas tratamentais. O pesquisador organizou as formas de tratamento do seguinte modo:

1) Tratamentos pronominais do tipo de tu, você, vocês, V.EX. "Vocês querem?" , "V.EX.. quer?";

2) Tratamentos nominais do tipo de a) o senhor, a senhora, os senhores, as senhoras; b) o senhor Dr., o senhor Ministro; c) o pai , a mãe, o avô; d) o Antônio, a Maria; e) o meu amigo, o patrão, etc. ; 
3) Tratamentos verbais, ou seja, a simples utilização da desinência do verbo como referência ao interlocutor: "Queres?", "Quer?", "Querem?".

Cintra (1986) distingue, ainda, as formas de tratamento do português europeu atual da seguinte maneira:

a) formas próprias da intimidade;

b) formas usadas no tratamento de igual para igual (ou de superior para inferior) e que não implicam intimidade; e

c) formas chamadas "de reverência" - "de cortesia"-, por sua vez repartidas por uma série muito variada de níveis, correspondentes a distâncias diversas, no sentido social e não de espaço, entre os interlocutores.

Quando o falante não dispõe das informações necessárias para a escolha da forma de tratamento apropriada, ele deve ater-se aos índices de contextualização, tais como a aparência física - rugas, cabelos grisalhos, modo de vestir, jeito de falar. Contudo, essa não é uma relação rígida, pois, como já mencionamos, as formas de tratamento podem variar de acordo com o contexto.

\subsection{As formas de tratamento no século XIX}

Não podemos desconsiderar o contexto histórico, social e econômico para a análise das formas de tratamento na peça $O$ Juiz de Paz da roça. É importante entender que o sistema das formas de tratamento acompanhou a evolução da língua portuguesa. Focalizaremos os estudos de Cintra (1986), Nascentes (1950) e de outros autores que pesquisaram as formas de tratamento no século XIX. 
Cintra (1986:123) destaca os principais usos das formas de tratamento no português moderno, ou seja, o português da segunda metade do século XVIII em diante:

\begin{tabular}{|c|c|}
\hline \multicolumn{2}{|c|}{ Singular } \\
\hline 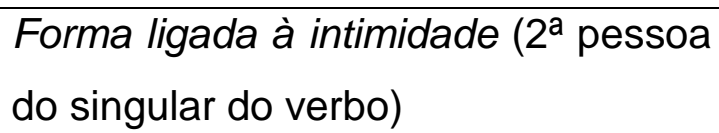 & $\begin{array}{l}\text { Formas de cortesia ( } 3^{\text {a }} \text { pessoa do singular } \\
\text { do verbo) }\end{array}$ \\
\hline TU & $\begin{array}{l}\text { a)vossa mercê (você), vossa senhoria, } \\
\text { vossa alteza, vossa majestade, vossa } \\
\text { excelência, etc. } \\
\text { b)o senhor, a senhora, o senhor doutor..., } \\
\text { o senhor director ...,o senhor ministro ..., o } \\
\text { senhor presidente } \\
\text { c) o Antônio, o Sr.Antônio, o Sr. Dr.Antônio, } \\
\text { o Sr. D. Antônio, a Maria, a D.Maria, a Sra } . \\
\text { Maria, a Srª. D.Maria, Sra . Drª.D.Maria. } \\
\text { d) O pai, a mãe, o avô, a avó, o tio, o meu } \\
\text { filho.... } \\
\text { e)O meu amigo, o patrão, o cavalheiro, } \\
\text { a "madame”... etc. }\end{array}$ \\
\hline
\end{tabular}

\begin{tabular}{|c|c|}
\hline \multicolumn{2}{|c|}{ Plural } \\
\hline $\begin{array}{l}\text { Forma indiferente (cada vez mais } \\
\text { própria do estilo oratório) } \\
\text { (2 } 2^{\mathrm{a}} \text { pessoa do plural do verbo) }\end{array}$ & $\begin{array}{c}\text { Formas de cortesia: } \\
\text { (3 } 3^{a} \text { pessoa do plural do verbo) }\end{array}$ \\
\hline vós & $\begin{array}{l}\text { a) vossas mercês, } \\
\text { b) Os senhores etc. } \\
\text { c) Os pais, os avós etc. } \\
\text { d) Os meus amigos, etc. }\end{array}$ \\
\hline
\end{tabular}

Os tratamentos como "o senhor Dr.", "o senhor Ministro' , por exemplo, remetem à categoria social ou à profissão e, no caso de "o pai”, “a mãe', ao 
parentesco. Segundo Cintra (1986), o tratamento nominal se distingue dos outros por ser caracterizador e por se opor, com as suas referências, a traços concretos e individualizadores. Expressões como "Vossa Senhoria" e "Vossa Excelência" são formas associadas à cortesia, ao respeito, à "reverência" e o pronome "você", por exemplo, já se encontrava em uso, embora esporadicamente, em textos do século XVIII como tratamento possível de igual para igual, entre amigos, mesmo os pertencentes à alta burguesia. O senhor e a senhora são, nas variantes americana e europeia do português, formas de respeito ou de cortesia e opõem-se a tu e você, em Portugal, e a você, na maior parte do Brasil.

No que concerne ao uso de tu e você, Cintra e Cunha (2001) salientam que, no português europeu normal, o pronome tu é empregado como forma própria da intimidade. Usa-se de pais para filhos, de avós ou tios para netos e sobrinhos, entre irmãos ou amigos, entre marido e mulher, entre colegas de faixa etária igual ou próxima. Eles destacam que seu emprego tem aumentado em certas famílias, de filhos para pais e tende a ultrapassar os limites da intimidade propriamente dita, em consonância com uma intenção igualitária ou aproximativa.

De acordo com Biderman (1972-1973:364), o uso de você circunscreve-se ao trato do superior ao inferior até meados do século XIX, levando em consideração critérios de idade, de posição e de iguais não íntimos ou de relação assimétrica. De acordo com essa autora, a substituição do tu por você como forma de tratamento familiar e íntima deve ter sido processada na virada do século XIX para o XX. Já Nascentes (1950:68), que realizou um importante estudo das formas de tratamento do século XIX e XX no Brasil, destaca que era comum misturar o tratamento tu-você no século XIX: 
Eu disse que o brasileiro julga bruto o tratamento de $t u$. Julga bruto, porém, o pronome reto. No pronome oblíquo emprega-o sem sentir brutalidade. Comumente, ouvem-se frases deste teor: "Você já esteve (repare-se na colocação do pronome, bem brasileira) na praia? Eu também estive, mas não te vi lá". Explica-se facilmente. Como pronome objetivo te é mais leve do que você. Se se empregasse você, a frase ficaria: "eu também estive, mas não vi você lá." Frase pesada. O brasileiro não usa $o$, a como objetivo de você. Usa o mesmo você do caso sujeito. Há certa repulsa por estas formas átonas. Parecem-nos vazias. Na língua literária, aparecem. $\mathrm{Na}$ língua dos que falam com apuro artificial, também aparecem. Mas na língua dos que falam desabotoadamente, como dizia D. Francisco Manuel de Melo, é que aparecem.

Segundo Lopes e Cavalcante (2011), a forma de tratamento você ganhou espaço no século XIX ao mesmo tempo em que formas alternantes de acusativo e dativo apareceram, além do clítico te. Você se instaurou no quadro de pronomes como sujeito preenchido e complemento preposicionado oblíquo. Embora a gramática tradicional condene a mistura de tratamentos tu e você, é muito recorrente frases do tipo "Você disse para eu te comunicar sobre o cancelamento do pedido".

Conforme as referidas pesquisadoras, Vosmecê, mecêa, vosse, você e a própria forma original Vossa Mercê chegaram ao Brasil em torno do século XII-XIV, sem indicar cortesia nos primeiros tempos. A forma vulgar você passou a ser produtiva nas relações assimétricas de superior para inferior.

O uso de você com tu acentuou-se nas relações mais íntimas e solidárias a partir do século XIX. As pesquisadoras afirmam que

Os estudos de Soto (2001, 2007), Lopes e Machado (2005), Rumeu (2008) e Lopes (2009) mostraram que o tratamento você no século XIX apresentava um comportamento híbrido e instável, pois aparecia tanto como uma estratégia de prestígio usada pela elite brasileira da época, quanto um tratamento geral em cartas de cunho doméstico ao lado de tu. (LOPES; CAVALCANTE, 2011:36)

No Brasil do século XIX, você se apresenta em variação com tu e carrega em si uma relativa formalidade. Lopes e Marcotulio (apud Rumeu 2012) postulam que o 
pronome você não se desvincula automaticamente de seus traços nominais (vossa mercê) e alterna-se com o pronome tu.

Nascentes (1950) sustenta que o tratamento íntimo entre iguais era o de você, em todo o Brasil, com exceção do Rio Grande do Sul, onde se usava o tu e se usa até hoje. Para ele, o brasileiro achava bruto o tratamento de $t u$, talvez pelo som do $u$. Além desses tratamentos, na época são outros tratamentos íntimos: menino, menina, rapaz, velho, velhinho, mano, mana, irmão, cunhado, parente.

No século XIX, Nascentes (1950:14) afirma que o primeiro tratamento familiar era o do filho para os pais. O filho tratava o pai por "papai", "senhor" e "você" e a mãe, por "mamãe", "senhora" e "você". "Senhor" e "senhora" indicavam austeridade, porque segundo o pesquisador, "os pais modernos rejeitam a Senhoria (como rejeitam os pedidos de bênção), dizendo que 'senhor é de escravos'”.

Em relação ao tratamento hierárquico, o referido estudioso sustenta que entre as pessoas de mesmo nível ou de inferior para superior, o tratamento usual era o de "senhor". Não era delicado chamar de "você" pessoa com que não se tinha intimidade. Nas palavras de Nascentes (1950:16-17):

É tratamento respeitoso o de senhor. O superior emprega-o com o inferior, para repreender, para marcar distância, evitar que tome confiança.(...) Tu é brutal e por isso, usado para ofender.(...) Você também é insultuoso, quando dado acintosamente a pessoa que deveria ser tratada por Senhor.

Os tratamentos autoritários, de superior para inferior, são você, tu e senhor. O último aparece entre homens educados. O superior educado não trata por você os seus subordinados, principalmente sendo estes pessoas instruídas, com curso ginasial, com curso universitário.

Atualmente, em quase todo território brasileiro o tu foi substituído por você como forma de intimidade. Segundo Cintra e Cunha (2001:292), você também se emprega, fora do campo de intimidade, como tratamento de igual para igual ou de superior para inferior. Em relação ao emprego do pronome vós (e 
correspondentemente ao da $2^{\underline{a}}$ pessoa do plural dos verbos), quando dirigido a um único interlocutor, começou a cair em desuso, tornando-se até mesmo um traço arcaizante de pessoas mais velhas ou provincianas e restringe-se, sobretudo, ao campo dos tratamentos de cortesia completamente entregue ao domínio das formas nominais e da $3^{\text {a }}$ pessoa verbal, tal como salienta Cintra (1986:34). Segundo explicação do próprio autor, esse desuso deve-se à rápida ampliação do campo de emprego de Vossa Mercê, de Vossa Senhoria e de Vossa Excelência. Vós e a desinência da segunda pessoa do plural nos verbos acabaram tornando-se uma maneira rude de se dirigir até mesmo a um amigo com quem não existia intimidade que permitisse o emprego de tu. De acordo com Cintra e Cunha (2001:285), o pronome vós praticamente desapareceu da linguagem corrente do Brasil e de Portugal. No entanto, ainda pode ser usado em discursos enfáticos para se dirigir a um auditório qualificado.

Em relação ao pronome vós com referência a uma só pessoa, é considerado normal como tratamento de cerimônia em português antigo e clássico e ainda se emprega em linguagem literária de tom arcaizante, para expressar distância ou apreço social.

Em relação ao português brasileiro atual, Bechara (2009) faz algumas observações em relação a algumas formas de tratamento, tais como o pronome você, hoje usado familiarmente, resultado da redução da forma de reverência Vossa Mercê. Caindo o pronome vós em desuso, usado nas orações, em estilo solene, emprega-se vocês como o plural de tu. O substantivo "gente" passa a ter classificação de pronome de tratamento quando empregado com referência a uma ou a um grupo de pessoas, sempre permanecendo na $3^{\text {a }}$ pessoa do singular. 


\subsection{Alterações fonéticas e fonológicas}

Os fenômenos de ordem fonética surgem em função de serem facilitadores da articulação dos fonemas. Por isso, são bastante empregados pelas camadas menos favorecidas (populares) e, inclusive, pelas camadas mais cultas, na linguagem informal. Na escrita, esses fenômenos são passíveis de representação e se configuram em variantes $^{30}$ linguísticas ortográficas também. De acordo com Urbano (2011b:159):

Considerando-se o nível fonético, a fala, diferentemente da escrita, está sujeita, por natureza, a muitas flutuações articulatórias (e auditivas), de caráter esporádico ou acidental, em função do seu ritmo, velocidade, aspectos emocionais e outros, frequentemente sem clara distinguibilidade auditiva (Cf. Koch et al., 2007:179). Mas quando pensamos em variantes prosódicas, temos em mente variantes formais perfeitamente identificáveis, de caráter permanente ou menos permanente.

Os escritores podem tentar reproduzir elementos prosódicos da fala das personagens, ou seja, os sons, o acento e a entoação. Para isto, necessita de recursos escritos que representem a fala na escrita.

Desde o latim, a língua portuguesa do Brasil tem sofrido e ainda sofre diversos processos de transformação fonética, que designamos de metaplasmos. Os metaplasmos são possíveis de representar na escrita. Há metaplasmos de aumento, supressão, transposição e transformação que dão novas formas de palavras. A seguir, os mais recorrentes em nossa língua portuguesa do Brasil:

a) Prótese: acréscimo de um fonema no início de uma palavra. Temos, por exemplo, "alembrar" por "lembrar".

\footnotetext{
30 Entendemos por "variantes" as diferentes formas linguísticas que são intercambiáveis por
} veicularem o mesmo sentido. 
b) Epêntese: acréscimo de um fonema no meio da palavra. Um exemplo da língua portuguesa brasileira atual que representa bem este fenômeno é a palavra "tábua", o qual encontramos a forma "tálbua" no discurso oral.

c) Suarabácti: acréscimo de um fonema no meio de um vocábulo para desfazer um grupo consonantal. Temos, por exemplo, kruppa > grupa > garupa.

d) Paragoge: acréscimo de um fonema no final da palavra. Temos, por exemplo, "mártire" por "mártir".

e) Aférese: perda de um fonema no início de uma palavra. Exemplo: "tá" por "está".

f) Síncope: perda de fonema medial. Exemplo: "tamém" para "também".

g) Apócope: perda de um fonema no final da palavra. Exemplo: "rapaz" por "rapá".

h) Haplologia: queda de uma sílaba medial, por haver outra igual ou semelhante. É uma modalidade de síncope. Exemplo: "paralepípedo" por "paralelepípedo”.

i) Metátese: deslocamento de um fonema em uma mesma sílaba ou em sílabas diferentes. Exemplo: "preguntar" por "perguntar".

j) Sístole: deslocamento do acento tônico de um vocábulo. Exemplo: "rubrica" para "rúbrica".

k) Diástole: deslocamento, por avanço, do acento tônico de um vocábulo. Exemplo: "gratuito" para "gratuíto".

I) Degeneração: processo de transformação do fonema /b/ em fonema /v/. Exemplo: "assobiar" para "assoviar".

m) Nasalização: transformação de um fonema oral a um fonema nasal. Exemplo: "identidade" para "indentidade".

n) Desnasalação: processo de transformação de um fonema nasal a um fonema oral. Exemplo: "homem" para "home". 
o) Assimilação: influência de um fonema sobre o outro provocando uma aproximação ou total identidade entre os fonemas. Pode ser vocálica ou consonantal. Exemplo: persona (uso antigo) pessoa (uso atual).

p) Dissimilação: transformação de um fonema para que ele se torne diferente de outro. Exemplo: "privilégio" para "previlégio"

q) Rotacismo: transformação do fonema /// em /r/. Exemplo: "voltar" para "vortar".

r) Lambdacismo: transformação do fonema /r/ em ///. Exemplo: "cabeleireiro" para "cabelelero".

s) Ditongação: transformação de uma vogal ou um hiato em "ditongo". Exemplo: "caranguejo" para "carangueijo".

t) Monotongação: transformação ou redução de uma vogal. Exemplo: "besouro" para "besoro".

u) Metafonia: nome dado à alteração do timbre ou altura de uma vogal. Exemplo: "diferente" para "deferente".

v) Nasalização: transformação de um fonema oral a um fonema nasal. Exemplo: "identidade" para "indentidade".

w) Palatização: transformação de um ou mais fonemas em uma palatal. Exemplo: “avião" para "avinhão".

x) Despalatização: transformação de fonemas palatais em um nasal ou oral. Exemplo: "cabeçalho" para "cabeçálio".

Os fenômenos elencados podem caracterizar o falante em uma interação, desde o local de habitação até o grau de instrução, mas devem ser analisados juntamente com os vários usos linguísticos. 


\subsection{Construindo uma imagem de si}

$\mathrm{Na}$ interação os interlocutores se instituem como atores sociais, a relação interpessoal implica também uma "imagem de si" que cada um dos participantes projeta e ressignifica durante o processo interacional. De acordo com Galembeck (2008:325), "a construção ou a desconstrução da imagem de si ou do outro constitui um fator determinante na interação verbal”. Durante a interação, os indivíduos constroem uma imagem perante o interlocutor e este pode ajudar a construí-la ou a desconstruí-la dependendo da situação.

O sociólogo Erving Goffman foi um dos principais estudiosos das interações face a face. Em Interaction Ritual (1967), o pesquisador consolida a noção de face, ou seja, a representação da imagem pública de um indivíduo. O objetivo do falante é preservar a sua própria face e preservar a face do outro interlocutor.

Mais tarde, Brown e Levinson (1987) desenvolvem estudos sobre a polidez no ato interacional com base no conceito de "face" de Goffman. Eles aprofundam o conceito de face e relacionam a linguagem ao comportamento social. Eles destacam que todo ser possui duas faces, a saber:

1) A face negativa, que corresponde à descrição de Goffman como os "territórios do eu", ou seja, o território corporal, espacial ou temporal. A face negativa envolve a contestação aos territórios do "eu", ou seja, a liberdade de ação e a liberdade de sofrer imposição. É o desejo de não ser impedido em suas ações e implica a não imposição do outro.

2) A face positiva, que corresponde às imagens valorizadoras que os interlocutores constroem e tentam impor na interação. É o desejo de aprovação social e de autoestima. 
A noção de face positiva e negativa apresenta o mérito de destacar as ligações estabelecidas entre os indivíduos e permitem a elaboração do conceito de "FTA" (Face Threatening Acts ou Atos Ameaçadores da Face) em uma interação. Os participantes são levados a desenvolver atos verbais e não verbais durante 0 ato interacional e, consequentemente, estão sujeitos às ações ameaçadoras das faces, como por exemplo:

1) Atos que ameaçam a face positiva do falante: a auto-humilhação, a autoconfissão, a desculpa, a autocrítica e outros comportamentos "autodegradantes";

2) Atos que ameaçam a face negativa do ouvinte: pedidos, ordens, elogios, conselhos, proibições, ofensas proxêmicas, contatos corporais inadequados, agressões visuais, perguntas "indiscretas";

3) Atos que ameaçam a face positiva do ouvinte: a reprovação, os insultos, as acusações, as críticas, a refutação, a injúria, a chacota e o sarcasmo; e

4) Atos que ameaçam a face negativa do falante: os agradecimentos, a aceitação de ofertas, as promessas.

Uma maneira utilizada para manter a face do interlocutor e minimizar a ação dos atos ameaçadores da face (FTA) é o emprego da polidez ou da cortesia. Entendemos por polidez ou cortesia a adequação social a um contexto determinado que preserva o caráter harmonioso de uma relação interpessoal. A polidez aumenta quando cresce a distância entre falante e ouvinte e se fundamenta nos direitos e nos deveres das pessoas nas trocas comunicativas, ou seja, é importante respeitar o contrato conversacional.

De acordo com essa proposta, a imagem social é vulnerável e pode sofrer constantes ameaças, que podem ser amenizadas por estratégias linguísticas ou por atitudes. Os participantes do ato interacional devem buscar um equilíbrio e procurar 
proteger a face, para evitar uma relação conflituosa. Por exemplo, sugerir que o interlocutor está errado pode ocasionar um desconforto, revelar um segredo pode acarretar brigas entre outros comportamentos interacionais.

Para Goffman (1967), a fala é socialmente organizada como um pequeno sistema de ações face a face que são mutuamente e ritualmente governadas, ou seja, um encontro social e a manutenção da face é uma forma de manter uma boa relação com o seu interlocutor.

Kerbrat-Orecchioni (2006) sustenta que a interação não é permeada somente de atos ameaçadores da face. Ela também considera que há atos "valorizantes" da face e propõe o conceito de FFA (Face Flattering Acts) ou Anti-FTA.

No âmbito desta pesquisa, preferimos o termo "imagem social" para "face" e consideramos as ocorrências de atos "valorizantes" e "desvalorizantes" da imagem social dos indivíduos durante o ato interacional, independentemente das noções de face positiva e negativa assinaladas anteriormente.

Por atos "valorizantes" da imagem social do indivíduo, consideramos que essa categoria engloba um aspecto verbal, tais como os elogios, os agradecimentos, os pedidos de desculpa, entre outros; e um aspecto não verbal, tais como fazer uma reverência, ajoelhar-se, aplaudir, entre outros.

Por atos "desvalorizantes" da imagem social do indivíduo, consideramos que essa categoria engloba um aspecto verbal, tais como a reprovação, os insultos, as acusações, as críticas, a refutação, a injúria, a chacota, o sarcasmo, o uso de perguntas "indiscretas", entre outros; e uma categoria não verbal, que engloba ofensas proxêmicas, contatos corporais inadequados, agressões visuais, entre outros. 
Salientamos, no entanto, que os aspectos verbais e não verbais devem ser considerados dentro de uma situação comunicativa. $\mathrm{O}$ ato de elogiar ou aplaudir, por exemplo, podem também, e eventualmente, ser usados em um sentido irônico para desvalorizar a imagem de outro indivíduo em vez de valorizá-lo. 


\section{CAPÍTULO 5: ANÁLISE DA PEÇA O JUIZ DE PAZ DA ROÇA}

A peça $O$ Juiz de Paz da roça inicia-se com a distribuição das personagens na peça por meio de didascálias que fornecem as identidades dos enunciadores do texto, ou seja, das personagens que irão exercer a função de representar um grupo social na peça. No início da peça, as personagens estão dispostas da seguinte maneira:

\section{Juiz de Paz}

Escrivão do Juiz de Paz

Manuel João, lavrador, guarda nacional.

Maria Rosa, sua mulher [de Manuel João]

Aninha, sua filha. [de Manuel João]

José da Fonseca, amante de Aninha

Inácio José

José da Silva

Francisco Antônio

Lavradores

Gregório

Negros

Manuel André

Sampaio

Tomás

A cena se passa na roça.

(Anexo, p. 196)

A lista de personagens começa com o Juiz de Paz e o Escrivão, identificados pela profissão exercida de cada um e não pelo nome próprio. O primeiro tem como trabalho a conciliação de pessoas e o segundo o auxilia e viabiliza as suas ordens. Como é de se esperar pelo título da peça, o Juiz de Paz exerce um papel fundamental na peça, uma vez que é por meio dele que o escritor faz a sua crítica social em relação aos costumes brasileiros da época. As outras personagens são designadas pelo nome próprio e com a respectiva função na peça. Os únicos que possuem sobrenome são José da Fonseca e José da Silva, ambos com prenomes 
idênticos a fim de se evitar uma possível confusão de nomes por parte do público/leitor.

É importante salientar que os negros não possuem nome na didascália inicial da peça, já que ainda viviam sob a condição de escravos e são apenas nomeados de "Negros", juntamente com a respectiva função de lavrador. Além de Manuel João ser lavrador e possuir escravos, ele também exerce a função de guarda nacional o que, na época, era uma força paramilitar organizada, por lei, no Período Regencial brasileiro para a manutenção da ordem. A Guarda Nacional defendia a Constituição, a liberdade, a independência e a integridade do Império.

Há basicamente três núcleos na peça: a) o núcleo familiar, representado por Manuel João, o pater famílias, sua esposa Maria Rosa e Aninha, a filha de ambos; b) o núcleo amoroso, que se concentra nos namorados Aninha e José da Fonseca; e c) o núcleo laboral em que há a interação de contraste e de autoridade por parte do Juiz de Paz em relação ao Escrivão e às demais personagens roceiras.

A primeira didascália com função locativa no texto indica o espaço geral de toda a ação: a cena de toda a ação passa-se na roça, com personagens oriundas de uma classe social mais baixa, a dos roceiros. Na época, a roça era todo o espaço distanciado dos centros urbanos, em especial da Corte (o Rio de Janeiro), que serve de referência central para a comparação do modo de vida dos brasileiros no período.

Com base na organização das personagens no início da peça e das personagens que aparecem no texto integral, selecionamos os seguintes tipos sociais para estudo: a) o Juiz de Paz, que representa a autoridade do local, juntamente com o Escrivão, que se configura apenas como funcionário do juiz, mas que exerce a autoridade, quando necessária; b) os roceiros, as personagens ingênuas e manipuladas pelo Juiz; c) os escravos, que aparecem em algumas cenas 
na peça; d) o vadio, representado por José da Fonseca; e, por fim, e) as mulheres que, consideramos, representam os hábitos femininos no século XIX e, por isso mesmo, configuram-se como tipos sociais.

Desde o princípio da peça, há uma relação de contraste entre as personagens. São personagens de diferentes níveis sociais, tais como o Juiz de Paz e o Escrivão do Juiz de Paz de um lado e de outro, as demais personagens roceiras. Podemos, com efeito, supor que as diferentes escolhas tratamentais e lexicais obedecem a uma coerência interna no texto, de acordo com o papel ou status da personagem na história.

Os três núcleos na peça $O$ Juiz de Paz da roça encontram-se nas várias relações hierárquicas reveladas pelas escolhas lexicais e pelas formas de tratamento, a saber:

a) Relação de cunho familiar - boa parte das cenas se passa no âmbito familiar de Manuel João, Maria Rosa, a esposa e Aninha, a filha do casal.

b) Relação de cunho laboral - as cenas do Juiz de Paz e do Escrivão se passam no local de trabalho de ambos, onde eles mantêm contato com as demais personagens para solucionar as queixas de cada uma. Há também menção ao local de trabalho de Manuel João junto com os demais lavradores, inclusive os escravos.

c) Relação de intimidade entre os interlocutores - a existência de proximidade/familiaridade entre os interlocutores gera escolhas tanto tratamentais quanto lexicais no texto. Esse tipo de relação acontece, sobretudo, no âmbito familiar de Manuel João, mas é variável. Há uma hierarquia interna entre eles, ora autoritária, ora solidária por parte de Manuel João em relação à esposa e à filha. O mesmo fato acontece na relação amorosa de Aninha e José da Fonseca 
d) Relação de autoridade - Esse tipo de relação destaca-se no texto com as personagens do Juiz, do Escrivão e de Manuel João. Os três exercem a autoridade perante os funcionários e perante a família, caso de Manuel João. Maria Rosa e Aninha representam o papel da mulher no século XIX, submissa ao pater-familias, figura de Manuel João.

Centramos a análise respeitando essas divisões hierárquicas entre as personagens, que se destacam ainda mais com as escolhas das formas de tratamento. Estudamos os papéis sociais conciliando os dados do contexto e os dados paralinguísticos, indicados no texto por meio das didascálias.

A pesquisa, além de levantar dados linguísticos do século XIX brasileiro, mostra o cuidado do escritor em inventariar o status e a representação linguística em variados papéis de uma sociedade, por princípio, extremamente conservadora.

Para o escritor, não basta simular os variados tipos sociais na peça, é preciso também criticá-los. O autor conta com as ações ou descrições da "fachada social" (aparência e vestuário, por exemplo) das personagens que contradizem os seus status e fornecem inúmeras pistas para que o leitor/espectador perceba qual é o status real das personagens na peça. Cada indivíduo na peça deve apresentar comportamentos convenientes de acordo com o papel social representado na peça e, quando acontece o desrespeito a esse comportamento, ocorre a crítica social delineada pelo autor.

\subsection{As escolhas lexicais em O Juiz de Paz da roça}

A língua falada por um indivíduo reflete tanto a língua de seu meio tanto o meio a que ele busca adaptar-se. É, dessa forma, dotada de um simbolismo social. Na peça analisada, O Juiz de Paz da roça, mostramos que Martins Pena utiliza 
palavras da língua falada e, com isso, retrata o momento em que vivia. Provavelmente, outros autores fazem o mesmo.

Dividimos a análise das escolhas lexicais em categorias, a saber:

5.1.1) Escolhas lexicais caracterizadoras da "fachada social" das personagens;

5.1.2) Escolhas lexicais caracterizadoras do espaço físico da ação;

5.1.3) Escolhas lexicais caracterizadoras do registro formal e informal; e

5.1.4) Escolhas lexicais caracterizadoras de costumes de brasileiros do século XIX no Brasil.

Para o estudo detalhado das escolhas lexicais, elegemos como materiais de referência o dicionário Houaiss, o Novíssimo Dicionário Aulete e o Dicionário UNESP do Português Contemporâneo. Os dois primeiros são reconhecidos materiais de referência para a língua portuguesa do Brasil e indicam, inclusive, os usos linguísticos dos verbetes. O Dicionário UNESP do Português Contemporâneo é concebido sob o enfoque dos usos linguísticos reunidos em um corpus de cerca de 90 milhões de itens lexicais em textos escritos no Brasil a partir de 1950. Todo esse material foi extraído do banco de dados do Laboratório de Lexicografia da Faculdade de Ciências e Letras de Araraquara da UNESP. Primeiramente, optamos por consultar o dicionário Houaiss na análise dos exemplos e, caso a definição do significado das palavras e dos usos linguísticos se repitam nos outros dicionários referidos, não faremos menção a esses na explicação dos exemplos. Para a explicação de alguns exemplos, tornou-se necessária uma investigação de usos linguísticos em sites de busca como o Google ${ }^{31}$ e o Dicionário inFormal ${ }^{32}$, dicionário disponível on-line para consulta. Segundo o próprio site, trata-se de um "dicionário

\footnotetext{
${ }^{31}$ www.google.com

${ }^{32}$ www.dicionarioinformal.com.br
} 
de português gratuito pela internet, onde as palavras são definidas pelos usuários. Uma iniciativa de documentar on-line a evolução do português".

\subsection{1) Escolhas lexicais caracterizadoras da "fachada social" das personagens}

A primeira parte da didascália da cena 4, transcrita a seguir, retrata a situação de Manuel João na história por meio de uma descrição da vestimenta. Ele é descrito como um lavrador, vestido de maneira simples e pobre, portando uma enxada no ombro, objeto de seu trabalho na roça. A personagem usa uma calça de ganga, cujo tecido se caracteriza pela sua simplicidade. Segundo o Houaiss, a palavra ganga data de 1577 e se caracteriza por ser "um tecido vulgar, geralmente azul ou amarelo, que antigamente se fabricava na Índia". Além de vestir uma calça de ganga, ele se veste com uma japona que, segundo Houaiss, é um agasalho geralmente usado por oficiais e praças por cima do uniforme:

Entra Manuel João com uma enxada no ombro, vestido de calça de ganga azul, com uma das pernas arregaçadas; japona de pano azul, e descalço. Acompanha-Ihe um negro com um cesto na cabeça e uma enxada no ombro, vestido de camisa e ceroulas de algodão.

(Cena 4, linhas 94-97 do Anexo, p. 201)

"Ganga" indica uma escolha lexical que caracteriza Manuel João como um lavrador simples, da roça, ou seja, a época, o ambiente e a classe social. Por outro lado, o uso da japona já indica a outra função de Manuel João, o de guarda nacional. No decorrer das cenas, fica claro que Manuel João veste a farda quando ele vai capturar José da Fonseca para levá-lo à cidade: 
Manuel João - Passa fora! Mulher, arruma esta sala, enquanto me vou fardar.

(Cena 5, linha 182 do Anexo, p. 204)

Maria Rosa - Não se dá maior injustiça! Manuel João está todos os dias vestindo a farda. Ora pra levar presos, ora pra dar nos quilombos ... É um nunca acabar.

(Cena 6, linhas 189-190 do Anexo, p. 205)

A seguir, na didascália inicial da cena 7, embora Manuel João tenha se fardado, ele ainda porta as mesmas calças, tamancos e chapéu de palha, mostrando que o autor caracteriza as personagens de forma a contrastar as vestimentas. Isto é, novamente, a personagem se veste de acordo com a profissão de guarda e também de acordo com a de lavrador. Ele está com a mesma vestimenta, porém porta uma jaqueta de chita, tecido conhecido também pelo seu pouco valor:

Entra Manuel João com as mesmas calças e jaqueta de chita, tamancos, chapéu de palha e um grande pau na mão.

Manuel João, entrando - Estou fardado. Adeus, senhora, até amenhã. (Dá um abraço.)

(Cena 7, linhas 197-200 do Anexo, p. 206 )

Quando Manuel João se veste como guarda, ele explicita "Estou fardado.", fato que por ser explicitado, parece distingui-lo dos demais.

Neste mesmo sentido de contraste, O Juiz de Paz é descrito na didascália inicial da cena 9, excerto reproduzido a seguir, de uma maneira humilde e, embora exerça um cargo de respeito e autoridade que demandaria uma vestimenta mais formal condizente com o cargo, ele se veste com um rodaque, ou seja, um casaco, porta chinelas verdes e não porta gravata, um acessório masculino utilizado em ambientes formais e de respeito: 
Casa do Juiz de paz. Haverá uma mesa com alguns papéis; cadeiras. Entra o Juiz de paz vestido de calça branca, rodaque de riscado, chinelas verdes e sem gravata.

(Cena 9, linhas 214-215 do Anexo, p.208)

Além desses contrastes, indicados pela vestimenta e referências linguísticas, o uso do léxico também inclui aspectos de configuração de classe social, haja vista o excerto a seguir, em que a pouca condição financeira de José da Fonseca é enfatizada com o termo "vintém", que era antigamente uma moeda de prata de pouco valor fabricada nas casas de moeda da Bahia, Pernambuco e Rio de Janeiro, segundo Houaiss e Aulete. A palavra data de 1624 e continua vigente em nossa língua portuguesa brasileira com o sentido de "pouco dinheiro ou quantia ínfima" segundo os dicionários consultados:

Aninha - O Sr. agora tem dinheiro, porque não me pede a meu pai? José da Fonseca - Dinheiro! .... nem vintém.

(Cena 2, linhas 40-41 do Anexo, p. 198)

Na mesma cena, José da Fonseca diz a Aninha que está pobre como Jó, referência à personagem bíblica Jó que perdeu tudo o que tinha. A expressão "estar pobre como Jó" continua presente no português brasileiro atual com o sentido de uma pessoa desprovida de bens, o que enfatiza ainda mais a condição financeira da personagem, como no excerto a seguir: 
José da Fonseca - Você sabe que eu agora estou pobre como Jó. Assim tenho pensado em uma coisa ... Nós nos casaremos na freguesia sem que teu pai o saiba, depois partiremos para o Rio de Janeiro para lá vivermos.

(Cena 2, linhas 47- 49 do Anexo, p. 198)

Na peça, José da Fonseca é a personagem caracterizada como "vadio", talvez preguiçoso, com comportamento diferente dos outros roceiros, trabalhadores. Talvez esta personagem possa ser enquadrada na categoria "malandragem", ou seja, aquele que além de ter "jogo de cintura", faz de tudo para escapar de situações adversas.

Vários termos são usados para descrevê-lo de maneira depreciativa. Um dos exemplos é "melquetrefe". O dicionário Houaiss registra como "mequetrefe", mas há variantes como "melcatrefe" e "melquetrefe", tal como está no texto para indicar um indivíduo com comportamento duvidoso:

Manuel João - Dê-me lá minha jaqueta e meu chapéu, que quero ir à casa do juiz de paz fazer queixa do que nos sucede. Hei-de mostrar àquele melquitrefe quem é Manuel João ... Vá , senhora, não esteja a choromingar.

(Cena 19, linhas 479- 481 do Anexo, p. 224)

Na mesma cena 19, Manuel João o chama de "vadio". O termo continua em uso no português brasileiro atual com o sentido de uma pessoa que não tem ocupação, exemplo reproduzido a seguir:

Manuel João - Misericórdia! Minha filha fugir com um vadio daqueles! Eis, aí está o que fazem as rusgas do Rio Grande. Se não fosse o Rio Grande, não haviam recurutas e minha filha não fugiria com um deles.

(Cena 19, linhas 475- 477 do Anexo, p. 224) 
Em outro momento da peça, o Juiz o chama de "bilitre", variante fonológica do termo "biltre", aparentemente em desuso na língua portuguesa brasileira atual. Nos dicionários consultados, "biltre" significa "aquele que age de forma vil", "infame": Juiz - Ah, então não é rebelião... Mas vossa filha casada com um bilitre destes?

(Cena 22, linha 544 do Anexo, p. 229)

Os usos de termos técnicos referentes à área jurídica ou os usos de termos que indicam autoridade são utilizadas pelo Juiz de Paz e pelo Escrivão. "Intimar" é um termo jurídico para o ato de fazer uma intimação, ou seja, trata-se de um ato judicial pelo qual se notifica determinadas pessoas segundo Houaiss e Aulete. A palavra está inserida nos usos cotidianos da língua portuguesa do Brasil com o sentido de dar ordens de forma impositiva, ou seja, geralmente a palavra é empregada em situações de autoridade. Na peça O Juiz de Paz da roça, o termo "intimar" é empregado pelo Escrivão na cena 5:

Escrivão - Venho da parte do senhor juiz de paz intimá-lo para levar um recuruta à cidade.

(Cena 5, linhas 155-156 do Anexo, p. 203)

Em uma conversa com Aninha, Maria Rosa deixa claro que o Juiz obriga Manuel João a ir à cidade, senão ele vai preso. O uso do termo "obrigar" indica também uma imposição, o que enfatiza também a posição e a autoridade do Juiz de Paz, como no exemplo a seguir: 
Aninha - Mas meu pai pra que vai?

Maria Rosa - Porque o juiz de paz o obriga.

(Cena 6, linhas 191-192 do Anexo, p. 205)

Há todo um trabalho de escolha lexical para caracterizar as atividades jurídicas do Juiz de Paz. Há uso de termos como "preparar audiência", "as reformas da Constituição", "está aberta a audiência", "requerimentos", "crime classificado no Código", "estão conciliados", "não posso deferir", "a Constituição não manda", "derrogar a Constituição", "suspender as garantias", "citar a Assembléia Provincial”, "tomarei apelação", "e eu embargo", "não concederei revista no auto do processo!", "não dê anistia a este rebelde", "está feichada a sessão", "comarcas". Outro termo usado no universo jurídico da peça é "meirinho", uso já antigo e que hoje foi substituído por "oficial de justiça". A seguir, reproduzimos alguns dos exemplos e os significados:

\begin{tabular}{|c|c|c|}
\hline Palavra & Definição no Houaiss & Exemplos \\
\hline preparar audiência & $\begin{array}{l}\text { sessão de tribunal em que se } \\
\text { interrogam as partes e as } \\
\text { testemunhas e proclama-se uma } \\
\text { sentença }\end{array}$ & $\begin{array}{l}\text { Juiz - Vamo-nos preparando para } \\
\frac{\text { dar audiência hoje. (Arranja a }}{\text { mesa) }} \\
\text { (Cena } 9 \text {, linha } 217 \text { do Anexo, p. } \\
\text { 208) }\end{array}$ \\
\hline $\begin{array}{l}\text { as reformas da } \\
\text { Constituição }\end{array}$ & $\begin{array}{l}\text { modificação de uma sentença } \\
\text { em grau de recurso }\end{array}$ & $\begin{array}{l}{[\ldots] \text { há-de reparar na }} \\
\text { insignificância do presente; } \\
\text { porém, II. mo Sr., as reformas da } \\
\text { Constituicão permitem a cada um } \\
\text { fazer o que quiser, e mesmo fazer } \\
\text { presentes; [...] } \\
\text { (Cena 9, linhas } 227-229 \text { do } \\
\text { Anexo, p. 208) }\end{array}$ \\
\hline
\end{tabular}




\begin{tabular}{|c|c|c|}
\hline Palavra & Definição no Houaiss & Exemplos \\
\hline conciliar & $\begin{array}{l}\text { conseguir acordo entre } \\
\text { (pessoas) ou entrar em acordo } \\
\text { com (outrem) }\end{array}$ & $\begin{array}{l}\text { Juiz - Estão conciliados. (Inácio } \\
\text { José, Gregório e Josefa Joaquina } \\
\text { saem.) Sr. Escrivão, faça o favor } \\
\text { de ler o outro requerimento. } \\
\text { (Cena 11, linhas } \mathbf{2 7 1 - 2 7 2 ~ d o ~} \\
\text { Anexo, p.212) }\end{array}$ \\
\hline deferir & $\begin{array}{l}\text { dar despacho favorável a (o que } \\
\text { se reivindica) }\end{array}$ & $\begin{array}{l}\text { Juiz - Não posso deferir por estar } \\
\text { muito atravancado com um } \\
\text { roçado; portanto, requeira ao } \\
\text { suplente, que é o meu compadre } \\
\text { Pantaleão. } \\
\text { (Cena 11, linhas 282-283 do } \\
\text { Anexo, p. 212.) }\end{array}$ \\
\hline derrogar & $\begin{array}{l}\text { alterar parcialmente (lei, } \\
\text { regulamento ou sentença), } \\
\text { mudando ou abolindo certas } \\
\text { disposições }\end{array}$ & $\begin{array}{l}\text { Juiz - A Constituição! ... Está } \\
\text { bem! ... Eu, o Juiz de paz, hei por } \\
\text { bem derrogar a Constituição! Sr. } \\
\text { Escrivão, tome termo que a } \\
\text { Constituição está derrogada, e } \\
\text { mande-me prender este homem. } \\
\text { (Cena 11, linhas 288-290 do } \\
\text { Anexo, p. 212.) }\end{array}$ \\
\hline garantias & $\begin{array}{l}\text { direitos, privilégios, isenções } \\
\text { que a Constituição de um país } \\
\text { confere aos cidadãos }\end{array}$ & $\begin{array}{l}\text { Manuel André - Isto é uma } \\
\text { injustiça! } \\
\text { Juiz - Ainda fala? Suspendo-lhe } \\
\text { as garantias... } \\
\text { (Cena 11, linhas 291-292 do } \\
\text { Anexo, p. 212) }\end{array}$ \\
\hline tomar apelação & $\begin{array}{l}\text { recurso das decisões definitivas } \\
\text { de primeira instância para juiz, } \\
\text { instância ou tribunal superior; } \\
\text { apelo }\end{array}$ & $\begin{array}{l}\text { José da Silva - Eu vou queixar- } \\
\text { me ao Presidente. } \\
\text { Juiz - Pois vá, que eu tomarei } \\
\text { apelação. } \\
\text { (Cena 11, linhas } 364-365 \text { do } \\
\text { Anexo, p. 215) }\end{array}$ \\
\hline embargar & $\begin{array}{lcr}\text { impedir, } & \text { opor obstáculo, não } \\
\text { permitir, } & \text { utilizando-se } & \text { do } \\
\text { embargo } & & \end{array}$ & $\begin{array}{l}\text { Juiz - Pois vá, que eu tomarei } \\
\text { apelação. } \\
\text { José da Silva - E eu embargo. } \\
\text { (Cena 11, linhas } 365-366 \text { do } \\
\text { Anexo, p.215) }\end{array}$ \\
\hline
\end{tabular}




\begin{tabular}{|c|c|c|}
\hline Palavra & Definição no Houaiss & Exemplos \\
\hline $\begin{array}{l}\text { não conceder } \\
\text { revista }\end{array}$ & $\begin{array}{l}\text { recurso cabível das decisões } \\
\text { finais das turmas ou câmaras de } \\
\text { um tribunal, no caso de } \\
\text { divergência jurisprudencial, } \\
\text { quanto ao modo de interpretar o } \\
\text { direito em tese }\end{array}$ & $\begin{array}{l}\text { Juiz - Embargue ou não } \\
\text { embargue, embargue com } \\
\text { trezentos mil diabos, que eu não } \\
\text { concederei revista no auto do } \\
\text { processo! } \\
\text { (Cena 11, linhas } 367-368 \text { do } \\
\text { Anexo 215) }\end{array}$ \\
\hline Dar anistia & $\begin{array}{l}\text { ato do poder público que } \\
\text { declara impuníveis delitos } \\
\text { praticados até determinada data } \\
\text { por motivos políticos ou penais, } \\
\text { ao mesmo tempo que anula } \\
\text { condenações e suspende } \\
\text { diligências persecutórias. }\end{array}$ & $\begin{array}{l}\text { Juiz- Sr. Escrivão, não dê anistia } \\
\text { a este rebelde, e mande-o agarrar } \\
\text { para soldado. } \\
\text { (Cena 11, linha } 370 \text { do Anexo } \\
\text { p.216) }\end{array}$ \\
\hline comarcas & $\begin{array}{l}\text { circunscrição judiciária, sob a } \\
\text { jurisdição de um ou mais juízes } \\
\text { de direito }\end{array}$ & $\begin{array}{l}\text { Juiz - Envergonhar-se de quê? O } \\
\text { senhor ainda está muito de cor. } \\
\text { Aqui para nós, que ninguém nos } \\
\text { ouve, quantos juízes de direito há } \\
\text { por estas comarcas que não } \\
\text { sabem aonde têm sua mão } \\
\text { direita, quanto mais juízes de paz } \\
\text {...E além disso, cada um faz o } \\
\text { que sabe. (Batem.) Quem é? } \\
\text { (Cena 21, linhas } 527-530 \text { do } \\
\text { Anexo p.227-228) }\end{array}$ \\
\hline
\end{tabular}

Essas escolhas lexicais, além de caracterizarem, aparentemente, o local de formalidade, também caracterizam a profissão de juiz. Uma das passagens que revela o status real da personagem Juiz é o momento em que ele diz ao Escrivão que irá consultar um letrado para saber qual despacho dar, o que revela que ele não era uma pessoa bem instruída para o cargo: 
Juiz - Vou, sim. Quero-me aconselhar com um letrado para saber como hei-de despachar alguns requerimentos que cá tenho.

(Cena 21, linhas 514- 515 do Anexo, p. 227)

Todo este trabalho de escolha lexical revela o universo jurídico que parece ser um mundo linguístico à parte desde aquela época.

\subsection{2) Escolhas lexicais caracterizadoras do espaço físico da ação}

O Rio de Janeiro da época era designado de "corte" na peça, uma vez que era a cidade onde residia a família real portuguesa. No texto, a corte é descrita em contraste com a roça, pano de fundo das ações na peça O Juiz de Paz da roça. A personagem José da Fonseca descreve o Rio de Janeiro de uma maneira fantasiosa para Aninha e faz várias comparações com elementos típicos da roça para que a menina tenha uma ideia da dimensão de uma sala de teatro, por exemplo. No teatro descrito por ele, cabem vinte pés de mangueira, elemento conhecido por Aninha na roça:

Aninha - O que há na corte de tão bom, que você não fala em outra coisa?

José da Fonseca - Eu te digo. Há dois teatros; em um deles pode caber vinte pés de mangueira.

Aninha - Oh! Como é grande!

(Cena 2, linhas 55- 58 do Anexo, p. 198)

Na mesma cena, José da Fonseca usa a presença de animais para mostrar a Aninha que as famosas ruas da Corte também tinham animais como a roça, mas de uma maneira diferente, como um "cabrito com duas cabeças". A menina acredita em tudo que ele diz, o que enfatiza ainda mais a sua ingenuidade: 
José da Fonseca - Além disto há outras muitas coisas. Na rua do Ouvidor há um cosmorama; na rua de S. Francisco de Paula, outro; e no Largo de S. Francisco há uma casa aonde se vêem muitos bichos cheios, muitas conchas, cabrito com duas cabeças e um jararacuçu vivo, que foi o que menos me admirou.

(Cena 2, linhas 77-80 do Anexo, p.199)

Aninha fica impressionada com a vida na Corte e a compara com a vida na roça, lugar este onde só se ouvem os "sapos" e "entanhas", este último como uma variante fonológica para "intanhas", forma encontrada nos dicionários e que significam grandes anfíbios:

Aninha, só - Como é bonita a corte! Lá é que a gente pode se divertir e não aqui aonde não se ouve senão os sapos e as entanhas cantarem! Teatros, mágicas, cavalos que dançam, cabrito com duas cabeças, quanta coisa! Eu quero ir para Corte.

(Cena 3, linhas 90-93 do Anexo, p. 200)

O espaço da corte obviamente não é o único. O espaço central é o da roça a que o espectador/leitor tem acesso pelas marcas cenográficas e linguísticas. Do ponto de vista linguístico, várias atividades relacionadas ao mundo da roça são tratadas em cena, caracterizando várias redes lexicais incorporadas do mundo roceiro, como por exemplo: "mandiocal", "terreiro", "cafezeiros", "bananal", "rapar mandiocas", "pés de mangueira", "sapos", "entanhas", "colher um pouco de café":

Aninha - Meu pai me disse que havia comprar uma negrinha para mim quando desmanchasse o mandiocal grande.

(Cena 1, linhas 13-14 do Anexo, p. 197)

Maria Rosa - É verdade! Tinha-me esquecido. Vai aí fora no terreiro, e traz-me dois limões. 
Aninha - Minha mãe já ia tardando a sair daqui. Eu pensava que não poderia falar hoje com o Sr.José da Fonseca. Ele está me esperando debaixo dos cafezeiros. [ ...]

(Cena 1, linhas 27-29 do Anexo, p. 197)

Aninha - Esta gente quando vai à corte vem perdida. Ora, diga-me, concluiu a venda do bananal que seu pai lhe deixou?

(Cena 2, linhas 37-38 do Anexo, p.198)

José da Fonseca - Ora tua mãe! Ela que fique rapando mandiocas, que é ofício leve. Vamos para corte, que você verá o que é bom.

(Cena 2, linhas 53- 54 do Anexo, p.198)

Aninha, só - Como é bonita a corte! Lá é que a gente pode se divertir e não aqui aonde não se ouve senão os sapos e as entanhas cantarem! Teatros, mágicas, cavalos que dançam, cabrito com duas cabeças, quanta coisa! Eu quero ir para Corte.

(Cena 3, linhas 90-93 do Anexo, p. 200)

Manuel João - Obrigado (bebendo a jacuba). Hoje trabalhei como gente... Limpei o mandiocal que estava muito sujo .... fiz uma derrubada do lado de Francisco Antônio .... e abri uma vala para esgotar as águas que estavam fazendo o feijão apodrecer... e hoje à tarde pertendo colher um pouco de café... Aninha?

(Cena 5, linhas 115-118 do Anexo, p. 202)

Manuel João - Quando acabares de jantar, pega em um samburá, e vai colher o café dos cafezeiros que estão à roda da casa.

(Cena 5, linhas 120-121 do Anexo, p. 202)

Josefa Joaquina - Eu trazia este presente para o Sr. Juiz.Queira perdoar não ser coisa capaz. Não trouxe mais porque a peste deu lá em casa, que só ficaram estas que trago, e a carijó que lá ficou.

(Cena 14, linhas 400- 402 do Anexo, p.219)

Juiz, com as galinhas nas mãos - Ao menos com esta visita lucrei. Sr. Escrivão, veja como estão gordas! Levam a mão abaixo. Então, que diz?

(Cena 15, linhas 408- 409 do Anexo, p.220)

Juiz - Faz-me muito favor. Tome o leitão e bote no chiqueiro quando passar. Sabe aonde é?

(Cena 11, linhas 330-331 do Anexo, p. 214) 
Além de essas escolhas lexicais serem fundamentais para a construção/descrição do universo da roça em relação à cidade para o leitor/espectador, isso destaca ainda mais todo o trabalho de Martins Pena para caracterizar os elementos da peça de forma contrastiva, tanto de personagens quanto de ambientes.

\subsection{3) Escolhas lexicais caracterizadoras do registro formal ou informal}

De modo geral, o registro informal caracteriza as personagens "roceiras", integrando a configuração social da personagem-tipo. Além disso, como já vimos anteriormente, o Juiz de Paz constitui uma dupla configuração: o universo linguístico de ordem jurídica, mais formal e o universo linguístico informal que muitas vezes "trai" as características específicas que a personagem provavelmente não queira extravasar. Registros formais e informais, no entanto, não caracterizam posições sociais, visto que esses registros são adaptáveis de acordo com a situação comunicativa.

Algumas expressões informais encontradas na peça $O$ Juiz de Paz da roça continuam presentes nas conversações cotidianas da língua portuguesa brasileira atual. É o caso, por exemplo, de "ficar de boca aberta":

José da Fonseca - Sim, maquinismo. Eu te explico. Há um homem que de repente vira-se macaco; paus tornam-se em cobras; um lenço queima-se nas mãos de um deles sem que botem fogo; e outras coisas que fazem a gente ficar de boca aberta.

Aninha-Oh! Como deve ser bonito!

(Cena 2, linhas 64-67 do Anexo, p.199)

Com o mesmo sentido atualmente, "ficar de boca aberta" significa ficar atônito, pasmo, surpreso diante de um acontecimento. O Houaiss registra a 
expressão como sendo informal e o Dicionário UNESP do português contemporâneo também. Aulete registra também a expressão, mas sem denominá-la de informal.

Outra expressão que continua em uso no português brasileiro atual é a expressão "como um burro" ou "pra burro", no sentido de grande quantidade ou intensidade. O Houaiss, por exemplo, registra o seu uso como informal:

Manuel João, senta-se - Estou que não posso comigo; tenho trabalhado como um burro.

(Cena 4, linhas 107-108 do Anexo, p. 201)

Em vários trechos da fala, as personagens usam o verbo "botar" em vez de "colocar" ou "pôr", forma que prevalece também em nosso português atual em um registro popular, como nos excertos abaixo:

José da Fonseca - Sim, maquinismo. Eu te explico. Há um homem que de repente vira-se macaco; paus tornam-se em cobras; um lenço queima-se nas mãos de um deles sem que botem fogo; e outras coisas que fazem a gente ficar de boca aberta.

(Cena 2, linhas 64- 66 do Anexo, p.199)

Manuel João - Olá, José, leva estas enxadas lá para dentro e vai botar este café no sol. (Vai-se o preto)

(Cena 4, linhas 104-105 do Anexo, p. 201)

Manuel João - Pois que coma laranja com farinha , ele não é melhor do que eu. Diabo! um dia destes eu ... Diabo de carne! ... hei-de fazer uma plantação ... Lá se vão os dentes!... Deviam ter botado esta carne de molho no corgo...

(Cena 5, linhas 141-143 do Anexo, p.203)

Juiz - Faz-me muito favor. Tome o leitão e bote no chiqueiro quando passar. Sabe aonde é?

(Cena 11, linhas 330-331 do Anexo, p. 214)

Aninha - Minha mãe, aqui está o café que colhi.

Maria Rosa - Bota aí no chão, para amenhã ir pra o sol.

(Cena 16, linhas 416-417 do Anexo, p.221)

José - Assim que botei os pés fora desta porta, encontrei com o juiz de paz, que me 
mandou prender para recuruta.

(Cena 18, linhas 447-448 do Anexo, p.223)

Juiz - Eu? Ora essa é boa! Eu entendo cá disso? Ainda quando é algum caso de embigada, passa; mas casos sérios, é outra coisa. Eu lhe conto o que me ia acontecendo um dia. Um meu amigo me aconselhou que, todas as vezes que eu não soubesse dar um despaicho, que botasse o seguinte: "Não tem lugar."

(Cena 21, linhas 517-520 do Anexo, p.227)

Outra expressão que indica a informalidade está presente na fala de José da Fonseca na cena 18. Trata-se da expressão "não tenho ofício nem benefício", que continua sendo usada nos dias de hoje:

José da Fonseca - Quem quisesse que não havia ser, pois eu sou solteiro, e não tenho ofício nem benefício.

(Cena 18, linhas 453- 454 do Anexo, p. 223)

A expressão só salienta a maneira de ser de José da Fonseca, uma personagem que não tem o que fazer, desocupado, vadio.

Há outro termo definido como informal e usado pelo Juiz de Paz. Na cena 21, o Juiz diz que está com a "pança cheia", expressão usada ainda nos dias de hoje para quem se alimentou demasiadamente:

Juiz - Agora que estamos com a pança cheia, vamos trabalhar um pouco. (Assentam-se à mesa.)

(Cena 21, linhas 511- 512 do Anexo, p. 227) 


\subsection{4) Escolhas lexicais caracterizadoras de costumes de brasileiros do século XIX no Brasil}

Nesta categoria, tratamos de forma sintética os usos lexicais recorrentes na peça O Juiz de Paz da roça no século XIX. Alguns usos lexicais encontram-se, possivelmente, em desuso na língua portuguesa brasileira atual e outros estão presentes em nossa língua.

Embora seja frequente o uso de "Adeus" para se despedir de alguém no português brasileiro atual, em $O$ Juiz de Paz da roça de Martins Pena o termo é empregado como saudação e como despedida. Segundo Costa (1951), era muito comum esse uso entre as pessoas da roça no século XIX. Para registrarmos esse uso na língua portuguesa do Brasil, consultamos o Dicionário Houaiss, em que consta também esse tipo de uso como saudação em Portugal. O dicionário registra para a palavra as seguintes acepções: 1) substantivo masculino (1538): palavra, gesto, sinal de despedida e, por vezes, de saudação. 2) por extensão, separação física; despedida. "Adeus" também é usado como interjeição segundo Houaiss. O dicionário Aulete não enfatiza o uso do "Adeus" como saudação, apenas menciona que a palavra pode ser usada às vezes como cumprimento. Em consulta a outro dicionário, desta vez o Dicionário UNESP do Português Contemporâneo organizado por Francisco S. Borba, constam apenas acepções relacionados ao ato de despedirse.

Como mencionado anteriormente, o termo "Adeus" foi usado tanto para saudação quanto para a despedida na peça $O$ Juiz de Paz da roça. Na cena 2, por exemplo, o termo registra saudação, uma vez que sabemos pela didascália que José da Fonseca entra em cena e se encontra com Aninha: 
Entra José da Fonseca vestido de calças e jaqueta branca

José da Fonseca - Adeus, minha Aninha! (Quer abraçar Aninha).

Aninha - Fique quieto, Sr.José. Eu não gosto destes brinquedos, eu quero casar-me com o senhor, porém não quero que me abrace antes de casar-nos.

(Cena 2, linhas 31-35 do Anexo, p. 198)

De igual modo, na cena 4, Manuel João entra em cena e usa como saudação "Adeus" para Aninha:

Entra Manuel João com uma enxada no ombro, vestido de calça de ganga azul, com uma das pernas arregaçadas; japona de pano azul, e descalço. Acompanha-lhe um negro com um cesto na cabeça e uma enxada no ombro, vestido de camisa e ceroulas de algodão.

Aninha - Abenção, meu pai.

Manuel João - $\underline{\text { Adeus, }}$ rapariga, aonde está tua mãe?

(Cena 4, linhas 94-100 do Anexo, p. 201)

Com o mesmo objetivo, na cena 5, Maria Rosa entra em cena e usa com Manuel João a saudação "Adeus" :

Entra M. Rosa, com uma tigela na mão, seguida de Aninha.

Manuel João - Adeus, Sra. Maria Rosa.

Maria Rosa - $\underline{\text { Adeus, }}$ meu amigo. Estás muito cansado?

(Cena 5, linhas 109-113 do Anexo, p. 202)

Na literatura da época, encontramos o uso de "Adeus" como saudação não só em Martins Pena, mas também em outros autores. Em Machado de Assis é possível identificar também usos recorrentes da época em alguns diálogos das personagens criadas pelo escritor. O autor, que viveu entre 1839 e 1908, empregou o termo "Adeus" com o sentido de saudação no conto Um erradio: 
"Saímos; fomos até o Campo da Aclamação, que ainda não possuía o parque de hoje, nem tinha outra polícia além da natureza, que fazia brotar o capim, e das lavadeiras, que batiam e ensaboavam a roupa defronte do quartel. Eu ia cheio do discurso do Elisiário, ao lado dele, que levava a cabeça baixa e os olhos pensativos. De repente, ouvi dizer baixinho:

- $\underline{\text { Adeus, }}$ loiô!

Era uma quitandeira de doces, uma crioula baiana, segundo me pareceu pelos bordados e crivos da saia e da camisa. Vinha da Cidade Nova e atravessava o campo. Elisiário respondeu à saudação:

- $\underline{\text { Adeus, }}$ Zeferina".

(ASSIS, Machado de. Um erradio. Obra Completa, vol. II, Rio de Janeiro: Nova Aguilar, 1994)

Neste mesmo período, José de Alencar foi um dos escritores pioneiros em tentar registrar a língua portuguesa do Brasil. Na peça teatral Mãe, José de Alencar emprega "Adeus" com o mesmo uso em função de saudação. A cena também se passa no Rio de Janeiro, na época de 1855, dezessete anos depois da peça de Martins Pena. O excerto selecionado, a cena 2 da peça de José de Alencar, passase entre as personagens Elisa e Joana, transcrito a seguir:

$$
\begin{aligned}
& \text { "[ ...] } \\
& \text { Joana - Bom dia, laiá. } \\
& \text { Elisa - Adeus, Joana. } \\
& \text { Joana - laiá está boa? } \\
& \text { Elisa - Boa, obrigada". }
\end{aligned}
$$

(ALENCAR, José de. Mãe. In: Antologia do teatro brasileiro: a aventura realista e o teatro musicado. Org. Flávio Aguiar. São Paulo: SENAC, 1998, p.17).

Na peça de José de Alencar, Joana e Elisa encontram-se e, enquanto uma personagem usa a expressão "Bom dia" para saudar a outra interlocutora, a personagem Elisa prefere o uso de "Adeus". 
Retornando ao corpus de Martins Pena, nos excertos escolhidos a seguir, "adeus" é usado também para a despedida. Na cena 2, sabemos que se trata de uma despedida porque Aninha pede para que o namorado vá embora por medo de ser vista pelo pai:

Aninha - Aí vem meu pai, vai-te embora antes que ele te veja. José da Fonseca - Adeus, até amenhã de menhã.

Aninha - Adeus, não faltes.

(Vai-se)

(Cena 2, linhas 86-89 do Anexo, p.199)

$\mathrm{Na}$ cena 7, Manuel João se despede de Maria Rosa e Aninha para ir à cidade, despedida enfatizada também pela expressão "Até amenhã" e pelo fato de as duas o acompanharem até a porta, atitude expressa pela didascália e ainda, uma última didascália que finaliza o texto indica a saída de Manuel João de cena:

Manuel João, entrando - Estou fardado. Adeus, senhora, até amenhã. (Dá um abraço.) Aninha - Abenção, meu pai.

Manuel João - Adeus, menina.

Aninha - Como meu pai vai à cidade, não se esqueça de trazer os sapatos franceses que Ihe pedi.

Manuel João - Sim, eu te trarei os sapatos. Adeus, minha gente.

Maria Rosa e Aninha - Adeus! (Acompanham-no até a porta.)

Manuel João, à porta - Não se esqueça de mexer a farinha e de dar que comer às galinhas.

Maria Rosa - Não. Adeus! (Sai Manuel João.)

(Cena 7, linhas 200-210 do Anexo, p. 206)

Outro termo usado em Martins Pena e que aparentemente está em desuso no português brasileiro atual é a interjeição "Apre!". Segundo Houaiss e Aulete, a interjeição data de 1526 e costuma expressar rejeição, aversão, aborrecimento e espanto: 
Escrivão, à parte - Em boa o diga. (À parte) Custou-me achar um guarda. Apre! Às vossas ordens.

(Cena 5, linhas 175-176 do Anexo, p.204)

Não consta a interjeição "Apre!" no Dicionário UNESP do Português Contemporâneo. Realizamos uma pesquisa em sites de busca da internet e no Dicionário inFormal on-line e, novamente, não encontramos a interjeição.

Há expressões usadas no texto não dicionarizadas, mas que podem ser facilmente compreendidas pelo contexto da história: é o caso, por exemplo, da expressão "ter campanha velha". Embora os dicionários consultados não registrem o seu significado, podemos empreender pelo contexto que se trata de uma briga entre o casal, uma vez que um dos sentidos de campanha é "operação militar":

Aninha - Minha mãe preparou a jacuba pra meu pai?

Maria Rosa - É verdade! Tinha-me esquecido. Vai aí fora no terreiro, e traz-me dois limões.

(Aninha sai)

Maria Rosa - Se o Manuel João não achasse sua jacuba, tínhamos campanha velha. Do que me tinha eu esquecido!

(Cena 1, linhas 17-22 do Anexo, p. 197)

Em consulta ao site Google e ao Dicionário inFormal, observamos que não consta essa expressão e, é possível que ela tenha caído em desuso na língua atual.

Outra expressão, "assentar praça", característica da época, parece não estar mais em uso no português do Brasil atual. Por isso mesmo, marca o período, quando empregada por José da Fonseca. Ora a expressão é grafada como "assentar praça", ora como "sentar praça" pela mesma personagem, José da Fonseca: 
José da Fonseca - Eu assentarei praça nos Permanentes.

(Cena 2, linha 51 do Anexo, p. 198)

José da Fonseca - E se teu pai não fosse incombido de me levar, estava perdido, havia de sentar praça.

(Cena 18, linhas 450-451 do Anexo, p. 223)

A expressão significa se alistar no exército para seguir carreira militar, embora conste no dicionário, parece que "assentar praça" ou "sentar praça" caiu em desuso no português brasileiro atual. No primeiro exemplo dado, "Permanentes" faz referência aos soldados que compunham o efetivo do exército na época.

Na didascália inicial da peça, antes das ações propriamente ditas, José da Fonseca aparece como amante de Aninha. Na época, a palavra "amante" tinha o mesmo sentido de namorado, apaixonado e não possui a conotação de hoje, ou seja, uma relação amorosa clandestina de/com uma pessoa casada:

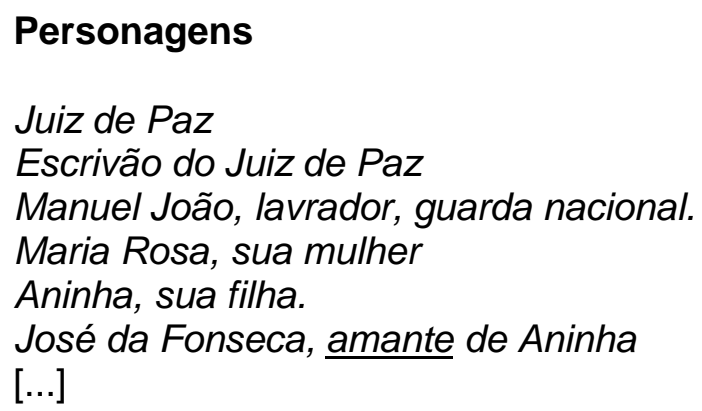

(Anexo p. 196)

Outra expressão usada na peça é "Quem as armou que as desarme”. Embora não conste a expressão em dicionários, podemos depreender pelo contexto de que se trata de resolverem os problemas aqueles mesmos que os causaram: 
Manuel João - Que me importa eu cá com isto? Que me importa com Rio Grande? Quem as armou que as desarme.

(Cena 5, linhas 163-164 do Anexo, p.203)

Além do exemplo dado, encontramos outra expressão usada no período, mas não dicionarizada é "estar de perninhas". De acordo com o contexto da história, podemos empreender que a expressão significa "escapar", "fugir":

Manuel João - E o que quer o senhor que se lhe faça? Ora essa é boa! Castigados precisam ser aqueles que foram causa de tudo isto. Ora não é má esta! Um pobre lavrador como eu ver-se obrigado a perder um dia de trabalho por causa do Rio Grande, ao mesmo tempo que aqueles que foram causa estão de perninhas a ganharem dinheiro. Não se dá maior patifaria! Ora esta!

(Cena 5, linhas 167-171 do Anexo, p. 203)

Há escolhas lexicais relacionadas ao período escravagista. Diante do regime escravocrata ainda vigente, mesmo com a proibição do tráfico negreiro, Maria Rosa, por exemplo, usa o termo "meias-caras" para os escravos contrabandeados. Nessa mesma rede lexical, o escritor Martins Pena também usa "preto" e "negrinha" para se referir aos escravos.

Maria Rosa - É verdade. Os meias-caras agora estão tão caros! Quando havia valongo eram mais baratos.

Aninha - Meu pai me disse que havia comprar uma negrinha para mim quando desmanchasse o mandiocal grande.

(Cena 1, linhas 11-14 do Anexo, p. 197)

Manuel João - Carne boa não faz conta, voa. Assente-se, venha jantar.

(Assentam-se todos e comem com as mãos. O jantar consta de carne seca, feijão e laranjas.) Não há carne seca para o preto?

(Cena 5, linhas 137-139 do Anexo, p. 202-203) 
Nesta mesma rede lexical relacionada ao mundo escravagista, o excerto dado faz uma referência ao local utilizado para a venda de escravos, os valongos. 0 dicionário Houaiss registra o termo "valongo" como obsoleto e não consta o verbete em Aulete, nos demais dicionários consultados e nos sites de busca da internet.

Outro termo relacionado ao mundo escravagista é "quilombos", lugar onde se refugiavam os negros:

Maria Rosa - Não se dá maior injustiça! Manuel João está todos os dias vestindo a farda. Ora pra levar presos, ora pra dar nos quilombos ... É um nunca acabar.

(Cena 6, linhas 189-190 do Anexo, p.205)

Em um requerimento lido durante a ação da peça, fica evidente a presença de escravos na vida dos brasileiros do período. A personagem José da Silva faz menção a sua escrava Maria, com quem tem um filho:

Escrivão, lendo - Diz Francisco Antônio, natural de Portugal, porém brasileiro, que tendo ele casado com Rosa de Jesus, trouxe esta por dote uma égua. [...] Ora, como os filhos pertencem às mães, e a prova disto é que minha escrava Maria tem um filho que é meu, peço a V.Sa . mande o dito meu vizinho entregar-me o filho da égua que é de minha mulher."

(Cena 11, linhas 351-357 do Anexo, p. 215)

É importante destacar que há, ainda, vários elementos que configuram a época da peça. O uso da palavra "província" é um exemplo. No Segundo Reinado do Brasil, a província era uma das grandes divisões administrativas do país e governada por um presidente. A palavra caiu em desuso, porque no período republicano as províncias tornaram-se estados: 
Escrivão - Meu amigo, isto pouco patriotismo. Vós bem sabeis que é preciso mandar gente para o Rio Grande; quando não podemos perder esta província.

(Cena 5, linhas 161-162 do Anexo, p. 203)

Outras palavras na peça parecem ter adquirido novos usos no decorrer do tempo. A palavra "freguesia", na peça, tem dois significados: o primeiro exemplo indica a povoação e, o segundo exemplo, tem significado de paróquia:

Escrivão, lendo - Diz Inácio José, natural desta freguesia e casado com Josefa Joaquina, sua mulher na face da Igreja, que precisa que Vossa Senhoria mande a Gregório degradado para fora da terra, pois teve o atrevimento de dar uma embigada em sua mulher, na encruzilhada do Pau-Grande, que quase a fez abortar, da qual embigada fez cair a dita sua mulher de pernas para o ar. Portanto pede a Vossa Senhoria mande o dito sujeito degradado para Angola. E.RM.

(Cena 11, linhas 252-257 do Anexo, p. 211)

José da Fonseca - Sim senhor, seu marido. Há muito tempo que nos amamos, e sabendo que vós não daríeis o vosso consentimento, fugimos e casamos na freguesia.

(Cena 20, linhas 488- 490 do Anexo, p. 225)

Atualmente, os dois significados continuam sendo usados, mas aparentemente com menos frequência. É mais recorrente o uso da palavra "freguesia" com o sentido de "clientela" no português brasileiro atual.

Neste sentido, há outra palavra presente na peça que continua sendo usada no português brasileiro atual, porém com um sentido mais específico. O termo "samburá" significava na época um cesto comum e, atualmente, "samburá" é mais usado com o sentido de "cesto de pescador". A peça registra duas variantes ortográficas e fonológicas, "samborá" e "samburá": 
Manuel João - Quando acabares de jantar, pega em um samburá, e vai colher o café dos cafezeiros que estão à roda da casa.

(Cena 5, linhas 120-121 do Anexo, p.202)

Casa de Manuel João. Entram Maria Rosa e Aninha com um samborá na mão.

(Cena 16, linha 412 do Anexo, p. 221)

Há outra palavra no texto que, aparentemente, não é tão usada nos dias de hoje. É o caso do verbo "iscar", usado no texto com o sentido de "incitar cães":

Aninha - Ora, ele podia ficar em casa; e se o juiz de paz cá viesse buscá-lo, não tinha mais que iscar a Jibóia e a Boca-Negra.

(Cena 6, linhas 193-194 do Anexo, p. 205)

No exemplo dado, Aninha diz à mãe que não era necessário "iscar" as cachorras, Jibóia e Boca-Negra, caso o juiz fosse prender Manuel João.

Não são só essas palavras que deixaram de ser usadas ou mudaram o uso no decorrer do tempo. A palavra "brejeiro", usada na peça pelo Juiz de Paz para ofender um roceiro que o afronta, modificou o uso no português brasileiro atual.

No português corrente, segundo Houaiss, "brejeiro" significa "quem gosta de se divertir e divertir outros com gracejos, brincadeiras etc." ; "brincalhão, gozador". $\mathrm{Na}$ peça, pelo contexto de ameaça e de briga, parece que "brejeiro" conserva o uso do português de Portugal. Como consta no Houaiss, no português de Portugal, "brejeiro" é empregado de maneira pejorativa e significa "desonesto", "trapaceiro", "malandro", "vagabundo": 
Manuel André - Isto é uma injustiça!

Juiz - Ainda fala? Suspendo-Ihe as garantias...

Manuel André - É desaforo...

Juiz, levantando-se - Brejeiro! ... (Manuel André corre; o Juiz vai atrás.) Pega ... Pega ... Lá se foi....Que leve o diabo. (Assenta-se.) Vamos às outras partes.

(Cena 11, linhas 291-295 do Anexo, p.213)

Além de das palavras levantadas até o momento, há ainda outros exemplos de termos que caíram em desuso aparentemente. É o caso de "meirinho":

Juiz - Sr. Escrivão, chame o meirinho. (Os dois apartando-se.) Espere, Sr. Escrivão, não é preciso. (Assenta-se.) Meus senhores, só vejo um modo de conciliar esta contenda, que é darem os senhores este leitão de presente a algum amigo. Não digo com isso que mo dêem.

(Cena 11, linhas 317- 320 do Anexo, p. 213)

Segundo Houaiss, "meirinho" significa um oficial de justiça e de acordo com o dicionário, já é um termo antigo. Outro termo aparentemente em desuso, presente na peça, é "marafona". O termo é usado para ofender a mulher de um roceiro e, segundo o Houaiss, a palavra possui duas acepções: trata-se de "uma boneca sem rosto, constituída de uma cruz de madeira recoberta de pano" e também tem o significado de "meretriz":

Josefa Joaquina - Bruxa é a marafona de tua mulher, malcriado! Já não se lembra que me deu uma embigada, e que me deixou uma marca rouxa na barriga? Se o senhor quer ver, eu posso mostrar.

(Cena 11, linhas 260-262 do Anexo, p.211)

As escolhas lexicais, além de marcarem a época, também refletem os costumes do período. A jacuba, por exemplo, segundo Houaiss, data de 1853, porém a peça é de 1838 e observa-se que a palavra já estava em uso: 
Aninha - Minha mãe preparou a jacuba pra meu pai?

Maria Rosa - Se o Manuel João não achasse sua jacuba, tínhamos campanha velha. Do que me tinha eu esquecido!

(Cena 1, linhas 17- 21 do Anexo, p. 197)

Aninha - Ela está lá dentro preparando a jacuba.

(Cena 4, linha 101 do Anexo, p. 201 )

Segundo Houaiss, a jacuba era uma papa de farinha de mandioca preparada com mel, açúcar ou rapadura e que se diluía com água e sumo de limão para servir como refresco, este aí presente na vida cotidiana das personagens. Os demais dicionários consultados registram o mesmo significado. Todos ainda arrolam variantes para o termo, como por exemplo, "chibé", "gonguinha", "sebereba" e "tiquara".

Para verificar se o termo "jacuba" ainda é recorrente no português do Brasil, consultamos o site do Dicionário inFormal. Na primeira acepção, consta que o termo "jacuba" virou uma gíria da Marinha do Brasil no sentido de refresco aguado. Neste mesmo sentido, o Houaiss registra jacuba como um refresco qualquer de sentido informal na Marinha.

Na segunda acepção do Dicionário inFormal, encontramos a mesma definição dos dicionários tradicionais já arrolados na pesquisa, mas com uma informação mais precisa: a definição afirma que a palavra "jacuba" é usada no Norte do Brasil.

Outras definições encontradas no verbete dão conta que "jacuba" é um nome de município no Brasil e também de um rio. Em consulta ao site Google, "jacuba" aparece como um prato a base de farinha e rapadura, muito utilizado no Brasil pelos tropeiros durante os séculos XVIII e XIX de acordo com o site Wikipédia. Consta também no Wikcionário, que se autodenomina um dicionário universal de conteúdo 
livre on-line, a definição de que se trata de um pirão de farinha de mandioca misturado com água fria na região de Florianópolis, Santa Catarina.

Outro costume assinalado e presente na peça é a dança. Na cena final, o Juiz de Paz chama a todos para comemorar o casamento de Aninha com uma tirana e um fado. O Houaiss registra "tirana" como "uma dança de roda com par solista, difundida em todo o Brasil, onde surgiu no final do século XVIII, e cuja coreografia inclui sapateado, requebros e, eventualmente, umbigada".

Houaiss também registra o "fado" como uma dança brasileira, "dada como voluptuosa, de uma, duas ou uma roda de pessoas, acompanhada de viola e às vezes com canto". O Houaiss data a palavra de 1852-1853, porém ela já aparece na peça que é de 1838:

Juiz - A menina não perde ocasião! Agora, o que está feito está feito. O senhor não irá mais para a cidade, pois está casado. Assim, não falemos mais nisso. Já que estão aqui, hão-de fazer o favor de tomar uma xícara de café comigo, e dançarmos antes disto uma tirana. Vou mandar chamar mais algumas pessoas para fazerem a roda maior. (Chega à porta.) ó Antônio! Vai à venda do Sr.Manuel do Coqueiro e dize aos senhores que há pouco saíram daqui que façam o favor de chegarem até cá. (Para José:) O senhor queira perdoar se o chamei de bilitre; já aqui não está quem falou.

(Cena 22, linhas 550- 557 do Anexo, p. 229-230)

Juiz - Sejam bem-vindos, meus senhores. (Comprimentam-se.) Eu os mandei chamar para tomarem uma xícara de café comigo e dançarmos um fado em obséquio ao Sr.Manuel João, que casou sua filha hoje.

(Cena Última, linhas 566- 568 do Anexo, p. 231)

A "umbigada", elemento presente na tirana, também é mencionada na peça.

Ela é a causa inclusive de uma briga entre os roceiros. Na peça, no entanto, aparece a variante fonológica e ortográfica "embigada":

Escrivão, lendo - Diz Inácio José, natural desta freguesia e casado com Josefa Joaquina, sua mulher na face da Igreja, que precisa que Vossa Senhoria mande a Gregório degradado para fora da terra, pois teve o atrevimento de dar uma embigada em sua mulher, na encruzilhada 
do Pau-Grande, que quase a fez abortar, da qual embigada fez cair a dita sua mulher de pernas para o ar. Portanto pede a Vossa Senhoria mande o dito sujeito degradado para Angola. E.RM.

Juiz - É verdade, Sr.Gregório, que o senhor deu uma embigada na senhora?

Gregório - É mentira, Sr. Juiz da paz, eu não dou embigadas em bruxas.

Josefa Joaquina - Bruxa é a marafona de tua mulher, malcriado! Já não se lembra que me deu uma embigada, e que me deixou uma marca rouxa na barriga? Se o senhor quer ver, eu posso mostrar.

Juiz - Não precisa mostrar, eu o creio.

Josefa Joaquina - Sr. juiz, não é a primeira embigada que este homem me dá; eu é que não tenho querido contar a meu marido.

Juiz - Está bom, senhora, sossegue. Sr.Inácio José, deixe-se destas asneiras, dar embigadas não é crime classificado no Código. Sr.Gregório, fará o favor de não dar mais embigadas na senhora; quando não arrumo-lhe com as leis às costas e meto-o na cadeia.Queiram-se retirar.

(Cena 11, linhas 252-269 do Anexo, p. 211)

Houaiss define a "umbigada" como "uma pancada com o umbigo que o dançarino solista dá naquele que o vai substituir nas danças de roda trazidas pelos escravos bantos". É devido à pancada que a roceira Josefa Joaquina se queixa ao Juiz de Paz, que não pode fazer nada por não ser um crime classificado no Código. O costume de dar "umbigadas" parece ter desaparecido no Brasil, embora o termo conste nos dicionários consultados.

As escolhas lexicais caracterizadoras da época e dos costumes colocam em evidência a vida social do século XIX no Brasil. Embora o léxico não seja o único fator determinante para a configuração das personagens-tipo, as escolhas lexicais são importantes para inseri-las no universo da época. 


\subsection{As formas de tratamento em O Juiz de Paz da roça}

Em termos de escolhas tratamentais na peça, consideramos os estudos de Braun (apud Kerbrat-Orecchioni 1990) e Kerbrat-Orecchioni (1990) para a teoria, complementados com o estudo dos atos "valorizantes" e "desvalorizantes" da imagem social das personagens. Esse estudo mostra-se adequado para a análise da preservação da imagem pública da personagem Juiz de Paz até a revelação do real papel que a personagem exerce na peça.

Adotamos dois eixos de análise, uma vez que consideramos que existem duas maneiras de utilizar as formas de tratamento: o tratamento direto e o tratamento indireto. Conforme já mencionamos, o tratamento direto é como os locutores e os interlocutores presentes na cena teatral dirigem-se uns aos outros durante a interação e o tratamento indireto é como os locutores mencionam ou tratam indiretamente os interlocutores que não participam do ato interacional no momento da fala, presentes ou não na cena. Levando em consideração esses aspectos e mais as indicações das didascálias, é possível traçar a caracterização das personagens na peça e explicar como elas são mantidas ou desvendadas pelos atos "valorizantes" e "desvalorizantes" da imagem social.

\subsection{1) A representação das mulheres}

Nesta primeira parte, analisamos as escolhas tratamentais entre Aninha e Maria Rosa, que constituem um subnúcleo feminino do núcleo familiar e depois centralizamo-nos na relação dessas duas mulheres na peça com as demais personagens, principalmente em relação às personagens masculinas. Aninha e Maria Rosa são responsáveis pelos afazeres domésticos da casa e também do campo, tais como apontam as didascálias e as ações. A primeira didascália 
relacionada à vida de Maria Rosa e Aninha aparece na cena 1, onde consta que as personagens estão cosendo:

Sala com uma porta no fundo. Alguns cestos estarão espalhados pela casa. No meio da sala uma mesa, junto da qual estarão cosendo Maria Rosa e Aninha.

(Cena 1, linhas 1-2 do Anexo, p. 197)

Na primeira cena da peça, Maria Rosa e Aninha interagem em uma relação de familiaridade apontada pelas formas de tratamento, uma vez que se trata de uma relação entre mãe e filha no ambiente doméstico. Um dos tratamentos escolhidos por Aninha para fazer referência à mãe é o pronome possessivo. Ele enfatiza a familiaridade entre as duas, destacando o elo familiar pela posse e estabelece a relação de proximidade entre elas, como nos exemplos extraídos do corpus a seguir:

Aninha - Minha mãe preparou a jacuba pra meu pai?

(Cena 1, linha 17 do Anexo, p. 197)

Aninha - Minha mãe, a carne seca se acabou.

(Cena 5, linhas 134 do Anexo, p. 202)

Aninha - Minha mãe, para que mandam a gente presa para cidade?

(Cena 6, linha 186 do Anexo, p. 205)

Aninha - Vamos, minha mãe. (Levam os pratos.)

(Cena 8, linha 213 do Anexo, p. 207)

Aninha - Minha mãe, aqui está o café que colhi.

(Cena 16, linha 416 do Anexo, p. 221)

Aninha - E minha mãe, me perdoa?

(Cena 20, linha 494 do Anexo, p. 225) 
Exceto o primeiro exemplo, "Minha mãe preparou a jacuba pra meu pai?", os demais exemplos estão com o possessivo na posição de vocativo, ou seja, uma forma linguística usada para chamamento ou interpelação ao interlocutor. O pronome possessivo indica valores afetivos, tanto de intimidade e amizade quanto de simpatia e de interesse, segundo Cintra e Cunha (2001). As formas escolhidas por Aninha expressam, então, proximidade e afetividade em relação à figura materna. Mesmo quando Maria Rosa não está presente no ato interacional, Aninha mantém o mesmo tratamento, quando a menciona para o público/leitor, sem a participação das outras personagens:

Aninha - Minha mãe já ia tardando a sair daqui. Eu pensava que não poderia falar hoje com o Sr.José da Fonseca. Ele está me esperando debaixo dos cafezeiros. Mas, como minha mãe está ocupada lá dentro e meu pai não entra nesta meia hora, eu posso fazê-lo entrar aqui. (Chega na porta e acena com o lenço). Ele aí vem.

(Cena 1, linhas 27- 31 do Anexo, p.197)

No exemplo dado, Aninha está falando com o público/leitor sobre o encontro com José da Fonseca, personagem que ainda não apareceu na história e que é desconhecida por Maria Rosa e Manuel João. José da Fonseca entrará em cena graças ao gesto de Aninha com um lenço, apontado na didascália "chega na porta e acena com um lenço". Ele entra em cena e começam uma interação na cena 2, em que José da Fonseca conta para Aninha os planos do casamento e da mudança para a cidade. Aninha fica preocupada com a mãe e pergunta para o namorado 0 que aconteceria caso mudasse para o Rio de Janeiro. Maria Rosa não está presente em cena e Aninha mantém o mesmo tratamento até então utilizado para se referir à mãe a José da Fonseca: 
Aninha - E minha mãe?

(Cena 2, linha 52 do Anexo, p. 198)

Em uma interação com o pai, Manuel João, Aninha usa o pronome sujeito de terceira pessoa para se referir à mãe, um uso mais neutro que não demonstra afetividade e nem proximidade na situação:

Manuel João - Adeus, rapariga, aonde está tua mãe?

Aninha - Ela está lá dentro preparando a jacuba.

(Cena 4, linhas 100-101 do Anexo, p. 201)

No exemplo dado, trata-se também de um tratamento indireto, visto que Maria Rosa não está presente no ato interacional.

O texto não detalha as características físicas das duas, há apenas menção de que se trata de uma família pobre em uma conversa com Manuel João. Maria Rosa, por exemplo, comenta a dificuldade para se achar um marido para moças pobres, entre elas, Aninha:

Maria Rosa - Eu já tinha pensado nisto; mas nós não somos ricos; e moça pobre custa a achar casamento.

(Cena 5, linhas 129-130 do Anexo, p. 202)

Por meio da caracterização geral "moça pobre", Maria Rosa insere a filha nesta categoria. Antes disso, ela também destaca que eles não são ricos, expresso pelo uso do pronome sujeito de primeira pessoa do plural "nós", que engloba toda a família: Manuel João, Maria Rosa e Aninha.

Em relação aos tratamentos usados por Maria Rosa para direcionar o diálogo para a filha, há diferentes usos dependendo da situação. Em geral, o tratamento 
preferido de Maria Rosa é o uso do diminutivo do nome Ana, Aninha. Não só de Maria Rosa, mas também é um tratamento usado pelo pai e conforme escolhido por Martins Pena, expresso pelas didascálias desde o princípio da peça. Em uma simulação de interação face a face, Maria Rosa registra vários usos no decorrer da peça:

Maria Rosa - Aninha, vai buscar o jantar de teu pai.

(Cena 5, linha 126 do Anexo, p. 202)

Nesta cena, Maria Rosa usa o diminutivo do nome de Ana com função de vocativo. O uso do diminutivo pode ser entendido de duas maneiras no contexto: a primeira destaca a juventude de Aninha, pois se trata de uma menina ainda de pouca idade e, a segunda, indica também uma linguagem mais afetuosa. Neste sentido, Skorge (apud Cintra e Cunha 2001:198) destaca que o sufixo diminutivo "indica ao leitor ou interlocutor que aquele que fala ou escreve põe a linguagem afetiva no primeiro plano". Em outro momento, porém, a mãe registra novamente o uso do diminutivo com a filha, agora com o adjetivo "tola" que, a princípio depreciativo e desvalorizante da imagem social, tem seu efeito de sentido amenizado pelo uso do diminutivo, que indica as tolices da juventude, a ingenuidade da menina:

Aninha - Mas meu pai pra que vai?

Maria Rosa - Porque o juiz de paz o obriga.

Aninha - Ora, ele podia ficar em casa; e se o juiz de paz cá viesse buscá-lo , não tinha mais que iscar a Jibóia e a Boca-Negra.

Maria Rosa - És uma tolinha! E a cadeia ao depois?

(Cena 6, linhas 191-195 do Anexo, p. 205) 
Outro uso escolhido por Maria Rosa é o tratamento nominal "Menina" usado como vocativo e que também enfatiza a pouca idade da personagem, como consta no exemplo a seguir:

Maria Rosa - Menina, ajuda-me a levar estes pratos para dentro. São horas de tu ires colher o café e de eu ir mexer a farinha ... Vamos.

(Cena 8, linhas 211-212 do Anexo, p. 207)

No mesmo exemplo, há o uso do pronome sujeito "tu" que, na época, era um indício de informalidade e proximidade entre os participantes da interação, o que confirma também a relação de familiaridade entre as personagens da peça. A referência ao mesmo pronome sujeito "tu" aparece sob a forma do possessivo "tua" e como oblíquo "te" na posição de dativo, como no exemplo a seguir:

Maria Rosa - E quando é que eu não hei-de perdoar-te? Não sou tua mãe? (Abraçam-se.)

(Cena 20, linhas 495- 496 do Anexo, p. 225)

Quando Maria Rosa e Aninha não interagem face a face, Maria Rosa mantém o tratamento "Aninha" e, em uma situação tensa, momento em que Maria Rosa descobre a fuga da filha com José da Fonseca, Maria Rosa usa tratamentos ultrajantes, tais como "maldita" e "ingrata", quando Maria Rosa está sozinha em cena ou com a presença de Manuel João:

Maria Rosa, entrando - Ó Aninha! Aninha! Aonde está esta maldita? Aninha! Mas o que é isto? Esta porta aberta? Ah! Sr. Manuel João! Sr. Manuel João!

(Cena 19, linhas 460- 461 do Anexo, p. 224)

Maria Rosa - Aninha fugiu com ele. 
Maria Rosa - Ingrata! Filha ingrata!

(Cena 19, linhas 478 do Anexo, p. 224)

Embora Maria Rosa use tratamentos depreciativos para se referir à Aninha, tais como "esta maldita" e "ingrata", aparentemente ela não quer desvalorizar a imagem social da filha e sim demonstrar decepção e raiva em relação ao comportamento da garota.

Em consonância com as escolhas tratamentais utilizadas pela mãe de Aninha, Manuel João adota usos idênticos ou parecidos na relação com a filha. Em um tratamento direto com a filha, ele usa, por exemplo, o tratamento "rapariga", geralmente usado para denominar mulheres na fase da adolescência:

Manuel João - Adeus, rapariga, aonde está tua mãe?

(Cena 4, linha 100 do Anexo, p. 201)

Como no exemplo utilizado por Maria Rosa, Manuel João adota o pronome possessivo de segunda pessoa para com a filha, o que expressa também informalidade e familiaridade entre as personagens. Como Maria Rosa, ele repete alguns tratamentos já usados pela esposa a Aninha, com o mesmo objetivo:

Manuel João - Obrigado (bebendo a jacuba). Hoje trabalhei como gente... Limpei o mandiocal que estava muito sujo.... fiz uma derrubada do lado de Francisco Antônio .... e abri uma vala para esgotar as águas que estavam fazendo o feijão apodrecer... e hoje à tarde pertendo colher um pouco de café... Aninha?

(Cena 5, linhas 115-118 do Anexo, p. 202) 
O primeiro exemplo usa o diminutivo do nome Ana; o segundo e o terceiro exemplos, "menina":

Manuel João - Adeus, menina.

(Cena 7, linha 203 do Anexo, p. 206)

Manuel João - Eu o tinha preso em meu quarto para levá-lo amenhã para a cidade; porém a menina, que foi mais esperta, furtou-me a chave e fugiu com ele.

(Cena 22, linhas 545-546 do Anexo, p. 229)

No último exemplo, de acordo com o contexto, Manuel João usa um elogio para valorizar a imagem social da filha. Ele desconhecia o elo amoroso entre a filha e José da Fonseca e a considerou "esperta" por ter conseguido a chave, fugir discretamente e, assim, casar com quem ela sonhava.

Quando Manuel João e Aninha não interagem em cena, Manuel João também usa os tratamentos "rapariga" e "Aninha" para se referir à filha quando interage com a esposa. Outro uso destaca também o possessivo "minha filha", usado como tratamento de posse e com uma possível demonstração de afetividade pelo contexto da cena. Nesta última ocorrência, Manuel João descobre que a filha fugiu com José da Fonseca, homem que havia prendido em sua casa para ser soldado e conhecido por ser vadio:

Manuel João - Senhora, sabe que mais? É preciso casarmos esta rapariga.

(Cena 5, linha 128 do Anexo, p. 202)

Manuel João - $\underline{\text { Aninha? } !}$

(Cena 19, linha 473 do Anexo, p. 224) 
Manuel João - Misericórdia! Minha filha fugir com um vadio daqueles! Eis, aí está o que fazem as rusgas do Rio Grande. Se não fosse o Rio Grande, não haviam recurutas e minha filha não fugiria com um deles.

(Cena 19, linhas 475-477 do Anexo, p. 224)

Além de todos esses usos apontados, o uso das formas de tratamento na peça O Juiz de Paz da roça mostra, em vários excertos, o retrato da família patriarcal brasileira. O status da mulher na sociedade patriarcal era de submissão, tanto na relação "marido-mulher" quanto na de "pai-filha".

Na peça, é frequente o tratamento de "senhor" para namorado ou marido por questão de respeito, tais como os exemplos do corpus a seguir:

Aninha - Minha mãe já ia tardando a sair daqui. Eu pensava que não poderia falar hoje com o Sr.José da Fonseca. Ele está me esperando debaixo dos cafezeiros. Mas, como minha mãe está ocupada lá dentro e meu pai não entra nesta meia hora, eu posso fazê-lo entrar aqui. (Chega na porta e acena com o lenço). Ele aí vem.

(Cena 1, linhas 27- 31 do Anexo, p. 197)

Neste excerto retirado da cena 1, Aninha dirige-se ao público/leitor para detalhar a sua intenção em cena, o futuro encontro com José da Fonseca, seu namorado secreto. Esta cena inclusive é fundamental para a apresentação da nova personagem em cena e para o andamento das próximas ações. Ela se refere ao namorado como "Sr.José da Fonseca", um tratamento extremamente formal e condizente com a época da peça, embora a personagem José da Fonseca ainda não esteja presente na interação de fato. $O$ uso deste tratamento pode ser explicado pelo fato de que Aninha está diante de desconhecidos (público/leitor), testemunhas de toda a interação na cena presente, que não participam da ação, mas que são passíveis de julgá-la moralmente. Em outros excertos, a menina mantém um 
tratamento de respeito em relação ao namorado no momento de interação face a face simulada, ora com o uso de "Sr.José", ora com o uso somente de "senhor" ou "Sr.", mesmo que teoricamente eles tenham uma relação de proximidade pelo elo amoroso:

Aninha - Fique quieto, Sr.José. Eu não gosto destes brinquedos, eu quero casar-me com o senhor, porém não quero que me abrace antes de casar-nos.

(Cena 2, linhas 34-35 do Anexo, p. 198)

Aninha - $\underline{\mathrm{O} S \mathrm{~S}}$. agora tem dinheiro, porque não me pede a meu pai?

(Cena 2, linha 40 do Anexo, p. 198)

Aninha - Deixemo-nos de comprimentos. Ora diga-me, como foi o senhor preso?

(Cena 18, linhas 446 do Anexo, p. 223)

Outro tratamento usado por Aninha na mesma cena insere o namorado na categoria "esta gente", termo cunhado pela garota para se referir às pessoas em geral que voltam da cidade (corte) com um comportamento mais liberal, pois ela profere esse termo quando o namorado ameaça abraçá-la em uma demonstração de carinho:

José da Fonseca - Adeus, minha Aninha! (Quer abraçar Aninha).

Aninha - Fique quieto, Sr.José. Eu não gosto destes brinquedos, eu quero casar-me com o senhor, porém não quero que me abrace antes de casar-nos.

José da Fonseca - Perdoa, minha Aninha.

Aninha - Esta gente quando vai à corte vem perdida. Ora, diga-me, concluiu a venda do bananal que seu pai lhe deixou?

(Cena 2, linhas 33 - 38 do Anexo, p. 198)

O abraço poderia ser considerado como um ato valorizante da imagem social de Aninha, pois demonstra afetividade e consideração em relação ao outro indivíduo. Na época, no entanto, pode ser considerado como um ato desvalorizante, 
visto que se trata de uma sociedade extremamente conservadora, principalmente porque se espera um comportamento recatado por parte das mulheres.

Embora o tratamento entre esposa/namorada seja de proximidade, deve-se levar em consideração a época em que o texto foi escrito, século XIX. Há de se ponderar, no entanto, que esse costume começou a ser modificado nesse período. De acordo com Freyre (2011), as mulheres ainda tratavam o marido por "senhor", mas as mais ousadas chamavam-no de "tu" e outras de "você", acabando com o rígido tratamento colonial de "senhor" da parte das esposas e dos filhos. Até então, esposas e filhos achavam-se quase no mesmo nível dos escravos. Neste sentido, Aninha também apresenta em seus diálogos essa mudança de comportamento da mulher brasileira na interação face a face entre ela e José da Fonseca:

Aninha - O que há na corte de tão bom, que você não fala em outra coisa?

(Cena 2, linha 55 do Anexo, p. 198)

Aninha - Quando é que você pertende casar-se comigo, para podermos ir para corte?

(Cena 2, linhas 81 - 82 do Anexo, p. 199)

Aninha - Aí vem meu pai, vai-te embora antes que ele te veja.

(Cena 2, linha 86 do Anexo, p. 199)

Aninha - Adeus, não faltes.

(Cena 2, linha 88 do Anexo, p.199)

Aninha - Você podia dizer que não queria ser soldado.

(Cena 18, linhas 452 do Anexo, p. 223)

É interessante notar que Aninha usa predominantemente o tratamento "você" em uma situação de interação face a face distensa, enquanto "tu" ocorre quando a menina percebe a aproximação do pai próximo à casa onde o casal está, situação, 
portanto, tensa. Nesta mesma cena 2, Aninha o trata por "senhor", "você", "tu". As duas últimas formas de tratamento indicam aproximação maior e intimidade entre os falantes, dentro da situação de comunicação. Ao que tudo indica, "você" é utilizado quando a conversação atinge um nível mais informal, sobretudo porque a cena não tem a presença dos pais de Aninha. Ao desenvolver ainda mais o diálogo e quando aumenta a tensão em cena, a menina usa o tratamento "tu", em que utiliza "ele te veja" e no exemplo com o verbo "faltar" conjugado na segunda pessoa do singular. Percebe-se que a fala de Aninha se desenvolve em uma gradação: começa de maneira formal e conforme o desenvolvimento do diálogo adquire um registro mais informal.

Embora a menina alterne um tratamento próximo e distante dependendo da situação comunicativa com o namorado, José da Fonseca sempre mantém um tratamento de proximidade com a namorada nas interações simuladas de face a face. Ele usa, por exemplo, o possessivo mais o diminutivo "Minha Aninha" em função vocativa:

José da Fonseca - Adeus, minha Aninha! (Quer abraçar Aninha).

(Cena 2, linha 33 do Anexo, p. 198)

José da Fonseca - Perdoa, minha Aninha.

(Cena 2, linha 36 do Anexo, p. 198)

José da Fonseca - Minha Aninha, não chores! Olha, se tu soubesses como é bonita a corte! ... Eu tenho um projeto que quero te dizer.

(Cena 2, linhas 44- 45 do Anexo, p. 198)

José, entrando - Oh, minha Aninha, eu te devo!

(Cena 18, linha 445 do Anexo, p. 223)

Nos exemplos apontados, José da Fonseca usa o pronome sujeito "tu", reconhecido como registro mais informal e próximo, em uma relação de intimidade. 
Ele também usa "você" em um registro de mais proximidade e informalidade, como constam também nos exemplos a seguir:

José da Fonseca - Você sabe que eu agora estou pobre como Jó. Assim tenho pensado em uma coisa ... Nós nos casaremos na freguesia sem que teu pai o saiba, depois partiremos para o Rio de Janeiro para lá vivermos.

(Cena 2, linhas 47- 49 do Anexo, p. 198)

José da Fonseca - Eu te digo. Há dois teatros; em um deles pode caber vinte pés de mangueira.

(Cena 2, linhas 56- 57 do Anexo, p. 198)

José da Fonseca - Sim, maquinismo. Eu te explico. Há um homem que de repente vira-se macaco; paus tornam-se em cobras; um lenço queima-se nas mãos de um deles sem que botem fogo; e outras coisas que fazem a gente ficar de boca aberta.

(Cena 2, linhas 64-66 do Anexo, p. 199)

José da Fonseca - Lembras bem. O vigário a estas horas deve estar na igreja; assim não tardemos.

(Cena 18, linhas 456- 457 do Anexo, p. 223)

Além de José da Fonseca e Aninha, a peça conta com outro casal: os pais de Aninha, Manuel João e Maria Rosa. Estes últimos mantêm uma relação oscilante em termos de formas de tratamento, tais como evidenciam alguns excertos da peça. Em uma interação simulada de face a face com Maria Rosa, Manuel João ora usa o termo "senhora" (às vezes acompanhado do nome próprio) ora usa o termo "mulher": Manuel João - Adeus, Sra. Maria Rosa.

(Cena 5, linha 111 do Anexo, p. 202)

Manuel João - Senhora, o jantar está pronto?

(Cena 5, linha 123 do Anexo, p. 202)

Manuel João - Senhora, sabe que mais? É preciso casarmos esta rapariga.

(Cena 5, linha 128 do Anexo, p. 202) 
Manuel João - Sim senhora, mas uma pessoa já me deu a entender .... Falaremos nisto com mais vagar.

(Cena 5, linhas 131-132 do Anexo, p. 202)

Manuel João - Passa fora! Mulher, arruma esta sala, enquanto me vou fardar. (Vai-se.)

(Cena 5, linha 182 do Anexo, p. 204)

Manuel João, entrando - Estou fardado. Adeus, senhora, até amenhã. (Dá um abraço.)

(Cena 7, linha 200-201 do Anexo, p. 206)

Manuel João - Amigo, venha cá. (Chega à porta do quarto e diz:) Você ficará aqui até amenhã. Lá dentro há uma cama; faça o favor de entrar. (Entra, e M.João feicha a porta.) Bom, está seguro. Senhora, vamos para dentro contarmos quantas dúzias temos de bananas para levar amenhã pra cidade. A chave fica em cima da mesa; lembrem-me, se me esquecer. (Saem Manuel João e Maria Rosa.)

(Cena 17, linhas 436- 440 do Anexo, p. 222)

Manuel João - O que dizes, mulher?!

(Cena 19, linha 466 do Anexo, p. 224)

Manuel João - Dê-me lá minha jaqueta e meu chapéu, que quero ir à casa do juiz de paz fazer queixa do que nos sucede. Hei-de mostrar àquele melquitrefe quem é Manuel João ... Vá, senhora, não esteja a choromingar.

(Cena 19, linhas 479-481 do Anexo, p. 224)

Manuel João - É preciso agora irmos dar parte ao juiz de paz que você já não pode ser soldado, pois está casado. Senhora, vá buscar minha jaqueta. (Sai Maria Rosa.) Então o senhor conta com o meu trabalho, não é assim?

(Cena 20, linhas 497- 499 do Anexo, p. 225)

Embora sejam marido e mulher, Manuel João prefere um termo mais distante, que não demonstra intimidade, mas ao mesmo tempo considerado um tratamento de igualdade. Aparentemente, o termo "mulher" é usado de acordo com o contexto situacional da cena. Manuel João o utiliza em momentos de tensão, como na 
ocasião que deve ir levar um recruta à cidade e no momento em que Maria Rosa relata a fuga de Aninha com José da Fonseca.

Maria Rosa mantém igualmente tratamentos oscilantes com Manuel João. Em geral, são termos que indicam familiaridade como "meu amigo", "você", "Manuel João", mas há também o uso de "Sr.Manuel João" no momento em que ela descobre a fuga de Aninha e chama o marido, situação, portanto, tensa:

Maria Rosa - Adeus, meu amigo. Estás muito cansado?

(Cena 5, linha 112 do Anexo p. 202)

Maria Rosa - Pensando que você viria muito cansado, fiz a tigela cheia.

(Cena 5, linha 114 do Anexo p. 202)

Maria Rosa - Manuel João! ...

(Cena 17, linha 424 do Anexo p. 222)

Maria Rosa, entrando - Ó Aninha! Aninha! Aonde está esta maldita? Aninha! Mas o que é isto? Esta porta aberta? Ah! Sr. Manuel João! Sr. Manuel João!

(Cena 19, linhas 460-461 do Anexo p. 224)

Quando Maria Rosa e Manuel João não interagem face a face, ela mantém um tratamento de igualdade, de familiaridade ou de neutralidade, quando faz referência ao marido para alguém:

Maria Rosa - Pobre homem! ... Ele mata-se em trabalhar! (...)

(Cena 1, linha 6 do Anexo p. 197)

Maria Rosa - Ele já me disse tãobém isso.

(Cena 1, linha 15 do Anexo p. 197)

Maria Rosa - Se o Manuel João não achasse sua jacuba, tínhamos campanha velha. Do que me tinha eu esquecido!

(Cena 1, linhas 21-22 do Anexo, p. 197) 
Maria Rosa - Pobre homem! Ir à cidade só para levar um preso! Perder um dia de trabalho $\cdots$

(Cena 6, linhas 184-185 do Anexo, p. 205)

Maria Rosa - Não se dá maior injustiça! Manuel João está todos os dias vestindo a farda. Ora pra levar presos, ora pra dar nos quilombos ... É um nunca acabar.

(Cena 6, linhas 189-190 do Anexo, p. 205)

Maria Rosa enfatiza a imagem de homem trabalhador com o termo "pobre homem" e em geral, prefere o uso do nome próprio sem o tratamento "Sr.". Percebese, então, que embora a relação homem-mulher seja uma relação de distância dentro de uma sociedade patriarcal, Maria Rosa já revelava uma mudança de comportamento da mulher para os padrões da época.

Em relação ao tratamento pai-filha, discutimos agora os tratamentos de Aninha e Manuel João. Aninha sempre obedece às ordens do pai, quando todos estão em cena, mostrando uma relação de respeito. Em relação aos tratamentos escolhidos por Aninha durante a interação com o pai, há tanto o uso de "meu pai" quanto de "senhor":

Aninha - Abenção, meu pai.

(Cena 4, linha 99 do Anexo, p. 201)

Aninha - Abenção, meu pai.

(Cena 7, linha 202 do Anexo, p. 206)

Aninha - Meu pai.

(Cena 5, linhas 119 do Anexo, p. 202)

Aninha - Como meu pai vai à cidade, não se esqueça de trazer os sapatos franceses que Ihe pedi.

(Cena 7, linhas 204-205 do Anexo, p. 206)

Aninha - Meu pai! ... 


\section{(Cena 17, linha 425 do Anexo, p. 222)}

Aninha - Meu pai, aqui está o meu marido.

(Cena 20, linhas 486 do Anexo, p. 225)

Tais como os tratamentos de Aninha com Maria Rosa, o uso do possessivo também indica proximidade e afetividade entre os dois. Em outros momentos da peça, Aninha adota o tratamento de respeito "senhor" para o pai. No exemplo extraído do corpus, na cena 5, Aninha usa o tratamento "senhor", quando responde a uma ordem de Manuel João:

Manuel João - Quando acabares de jantar, pega em um samburá, e vai colher o café dos cafezeiros que estão à roda da casa.

Aninha - Sim senhor.

(Cena 5, linhas 120-122 do Anexo, p. 202)

Na mesma cena, Aninha repete o uso de "senhor", quando responde a uma pergunta do pai durante o jantar. Neste momento da cena, ela recebe a ordem da mãe para buscar o jantar do pai e, quando ela retorna à cena, ela fala para os pais que a carne seca acabou e que não há carne suficiente para o escravo:

Maria Rosa - Aninha, vai buscar o jantar de teu pai.

(Vai- se Aninha).

$[\ldots]$

(Entra Aninha com dois pratos e os deixa na mesa)

Aninha - Minha mãe, a carne seca se acabou.

Manuel João - Já?! ...

Maria Rosa - A última vez veio só meia arroba.

Manuel João - Carne boa não faz conta, voa. Assente-se, venha jantar.

(Assentam-se todos e comem com as mãos. O jantar consta de carne seca, feijão e laranjas.) Não há carne seca para o preto?

Aninha - Não senhor.

(Cena 5, linhas 126-140 do Anexo, p. 202-203) 
A terceira ocorrência de "senhor" por Aninha para tratar o pai acontece em outro momento de submissão à figura paterna, uma vez que ela espera o consentimento do pai na aceitação de seu casamento às pressas com José da Fonseca. Para enfatizar essa posição submissa, Aninha e José da Fonseca ajoelham-se diante de Manuel João, atitude expressa pela didascália inicial na cena 20, excerto transcrito a seguir:

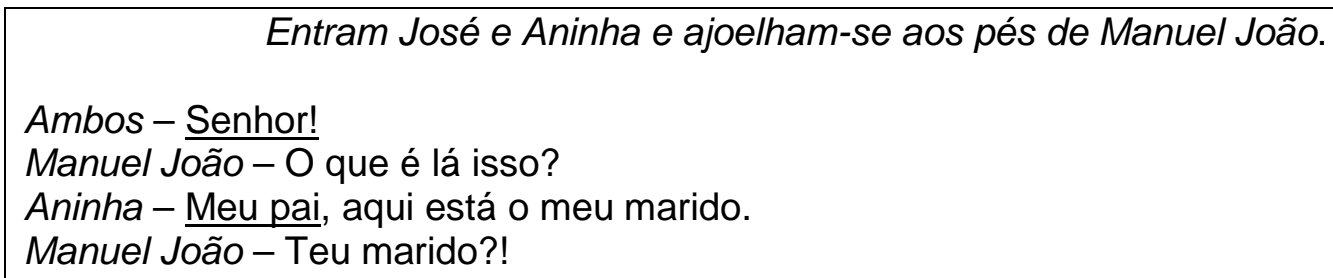

(Cena 20, linhas 484- 487 do Anexo, p.225)

O ato de ajoelhar-se enfatiza e valoriza a imagem de pater-famílias de Manuel João, visto que é ele quem deve dar o consentimento do casamento já realizado sob pena de Aninha ser castigada. Após esse momento de submissão, reafirmada pelo gesto e pela atitude de José da Fonseca e Aninha, a menina volta ao tratamento usado em outras cenas, ou seja, o uso do possessivo "meu pai".

Quando Manuel João não está presente no momento da interação, Aninha sempre mantém o possessivo "meu pai" tanto na conversação entre José da Fonseca quanto na conversação entre Maria Rosa:

Aninha - Meu pai, quando principia um trabalho, não gosta de o deixar sem acabar (...)

(Cena 1, linhas 9-10 do Anexo, p. 197)

Aninha - Meu pai me disse que havia comprar uma negrinha para mim quando desmanchasse o mandiocal grande.

(Cena 1, linhas 13-14 do Anexo, p. 197)

Aninha - Minha mãe preparou a jacuba pra meu pai? 


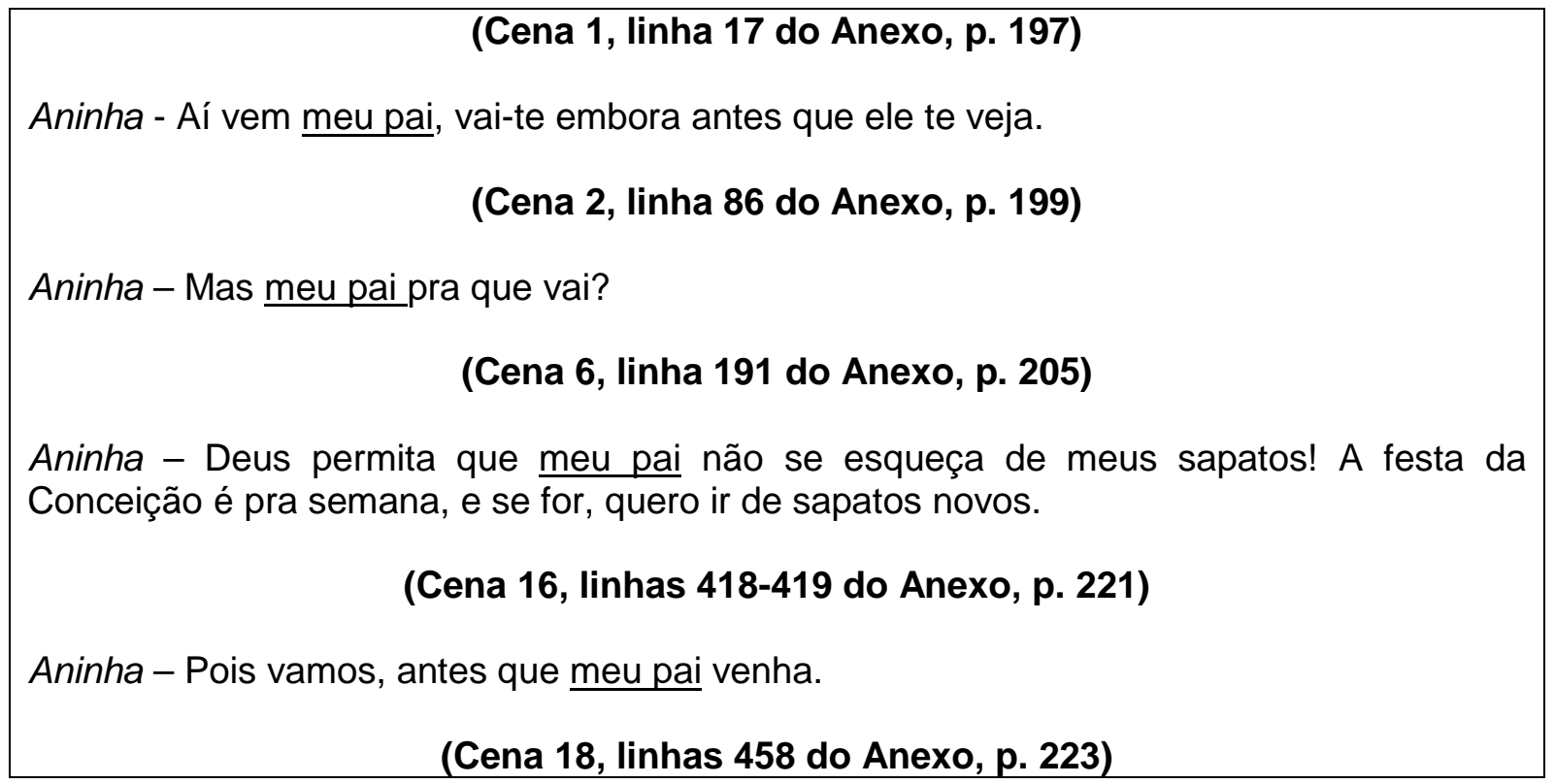

Em outra ocorrência, ela usa o pronome sujeito de terceira pessoa com uma função neutra, sem indicar proximidade nem afetividade:

Aninha - Ora, ele podia ficar em casa; e se o juiz de paz cá viesse buscá-lo, não tinha mais que iscar a Jibóia e a Boca-Negra.

(Cena 6, linhas 193-194 do Anexo, p. 205)

Por meio dos exemplos dados, as formas de tratamento revelam a posição submissa da mulher dentro da sociedade patriarcal do século XIX. No entanto, transformações no comportamento da mulher da época também refletem as escolhas tratamentais, ou seja, as mudanças sociais refletem nas escolhas tratamentais e nos usos linguísticos em geral.

\subsection{2) A representação dos escravos}

$\mathrm{Na}$ didascália inicial da peça, aquela em que são apresentadas as personagens antes do início das ações, os escravos não são nomeados, mas são denominados como negros que, por sua vez, exercem a função de lavradores. No 
decorrer da peça, no entanto, alguns momentos são lhes atribuídos nomes, conforme o exemplo a seguir em que o escravo é "José":

Manuel João - Olá, José, leva estas enxadas lá para dentro e vai botar este café no sol. (Vai-se o preto)

(Cena 4, linhas 104-106 do Anexo, p. 201)

Embora o escravo esteja presente no ato interacional do exemplo dado, em nenhum momento ele tem voz, apenas obedece às ordens das demais personagens, no caso do exemplo, Manuel João.

Em outro momento da peça, um escravo obedece às ordens de outra personagem e leva uma carta e presentes para a personagem do Juiz de Paz. Este usa um tratamento comum na época para se dirigir ao escravo: "pai":

[...] Ó pai, leva estas bananas para dentro e entrega à senhora. Toma lá um vintém para teu tabaco.(Sai o negro.) O certo é que ser juiz de paz é bem bom. Nós temos de vez em quando nossos presentinhos, ora de farinha, ora de galinhas e etc. (Batem na porta.) Quem é? [...]

(Cena 9, linhas 232- 236 do Anexo, p. 208)

O Juiz trata o escravo por "Ó pai", usado como vocativo para chamá-lo, um típico tratamento na época para os escravos e também o trata por "tu" por meio do possessivo "teu" expresso também pelo verbo "toma" no imperativo. De acordo com Costa (1951), "Pai" era um tratamento que se dava muito aos negros velhos escravos e esse uso se deve à tradução da obra Uncle Tom's Cabin de Harriet Beecher Stowe, em português $A$ cabana do Pai Tomás. O Dicionário Houaiss registra que "pai" era um tratamento afetuoso dado antigamente aos idosos, em especial aos escravos. 
Em outros momentos do texto, no entanto, não há demonstração de um tratamento afetuoso. Em uma conversa com Aninha, sem a presença dos escravos em cena, Maria Rosa se refere aos escravos de uma maneira mais grosseira e desvalorizante, como os excertos a seguir:

Maria Rosa - É verdade. Os meias-caras agora estão tão caros! Quando havia valongo eram mais baratos.

(Cena 1, linhas 11-12 do Anexo, p. 197)

Na época, os meias-caras eram os escravos contrabandeados para o país, após a proibição do tráfico negreiro. Nesse contexto, os escravos são considerados como meros "objetos", uma "propriedade" da família. No próximo exemplo, "maldito negro" usado de modo injurioso por Maria Rosa, após um dia cansativo e de muito serviço doméstico:

Casa de Manuel João. Entram Maria Rosa e Aninha com um samborá na mão.

Maria Rosa - Estou que não posso comigo! Já mexi meio alqueire de farinha, e por hoje basta.

Aninha - Minha mãe, aqui está o café que colhi.

Maria Rosa - Bota aí no chão, para amenhã ir pra o sol.

Aninha - Deus permita que meu pai não se esqueça de meus sapatos! A festa da Conceição é pra semana, e se for, quero ir de sapatos novos.

Maria Rosa - Aonde estará aquele maldito negro?

(Cena 16, linhas 412- 420 do Anexo, p. 221)

Na primeira cena da peça, em uma interação entre Aninha e Maria Rosa, sem a presença dos escravos, elas relatam a dificuldade do árduo trabalho de Manuel João, uma vez que ele tem somente um escravo, Agostinho. O escravo é nomeado neste momento da interação, porém não há coerência por parte do autor da peça em 
relação às personagens, visto que em outra cena o mesmo escravo é nomeado de José. Na peça, Manuel João tem apenas um escravo que é chamado de José na cena 4, mas na cena 1 Manuel João chama o escravo de Agostinho. Talvez para evitar a confusão por parte dos leitores/espectadores (a peça já conta com outros “Josés", tais como José da Fonseca e José da Silva), o comediógrafo tenha mudado o nome para Agostinho, porém esqueceu-se de modificar o nome do escravo de Manuel João na outra cena:

Aninha - Meu pai, quando principia um trabalho, não gosta de o deixar sem acabar, e minha mãe bem sabe que ele tem só a Agostinho.

Maria Rosa - É verdade. Os meias-caras agora estão tão caros! Quando havia valongo eram mais baratos.

Aninha - Meu pai me disse que havia comprar uma negrinha para mim quando desmanchasse o mandiocal grande.

(Cena 1, linhas 9-14 do Anexo, p. 197)

$\mathrm{Na}$ mesma conversação, Aninha refere-se aos escravos, em especial às escravas, como "negrinha". Manuel João havia prometido à filha a compra de uma escrava, quando desmanchasse um mandiocal. Na época, as mulheres eram designadas para os serviços domésticos, mas podiam contar com a ajuda de escravas, dependendo do nível econômico da família. Como retrata a peça, o tráfico negreiro já estava proibido, o que ocasionou a alta dos preços para a compra de escravos. Embora não houvesse agressões físicas em termos de castigo contra os escravos na peça, eles não recebiam tratamento afetuoso nas cenas. Um exemplo disso acontece durante o jantar da família. Manuel João pergunta a Aninha se não havia carne seca para "o preto" e, diante da negação da filha, ele não se importa com o fato e ainda salienta que o escravo não era melhor que ele:

Manuel João - Carne boa não faz conta, voa. Assente-se, venha jantar. (Assentam-se todos e comem com as mãos. O jantar consta de carne seca, feijão e laranjas.) Não há carne seca para o preto?

Manuel João - Pois que coma laranja com farinha, ele não é melhor do que eu. Diabo! um 
dia destes eu ... Diabo de carne! ... hei-de fazer uma plantação ... Lá se vão os dentes!... Deviam ter botado esta carne de molho no corgo...Que diabo de laranjas tão azedas! (Batem na porta) Quem é? (Logo que Manuel João ouve bater na porta, esconde os pratos na gaveta e lambe os dedos.)

(Cena 5, linhas 137-145 do Anexo, p. 202-203)

Como já mencionamos, os negros não interagem em termos conversacionais com as demais personagens, apenas representam a época histórica em que a peça está inserida. Eles estão presentes nos diálogos das personagens ou colaboram para a continuidade de uma ação, tal como foi mostrado no exemplo do Juiz de Paz com o escravo na cena 9.

É necessária também um estudo das didascálias da peça para a análise dos tratamentos dos escravos, uma vez que elas também representam a enunciação do autor da peça. Por meio das didascálias, os escravos são apenas designados ora por "negro" ora por "preto", tal como consta nos excertos a seguir:

Manuel João - Olá, José, leva estas enxadas lá para dentro e vai botar este café no sol. (Vai-se o preto)

(Cena 4, linhas 104-106 do Anexo, p. 201)

Juiz - Vamo-nos preparando para dar audiência hoje. (Arranja a mesa) O escrivão já tarda; sem dúvida está na venda do Manuel do Coqueiro... [...] (Batem na porta.) Quem é? Pode entrar. (Entra um negro com um caicho de bananas e uma carta, que entrega ao Juiz.Juiz, lendo a carta: ) [...]

(Cena 9, linhas 217-222 do Anexo, p. 208)

Ó pai, leva estas bananas para dentro e entrega à senhora. Toma lá um vintém para teu tabaco. (Sai o negro.)

(Cena 9, linhas 232-234 do Anexo, p. 208)

Dessa maneira, percebe-se que os escravos marcam a época da peça e contribuem para o andamento de algumas ações, mas não possuem voz e nem 
importância social, uma vez que são considerados como meros objetos. Caracterizam, assim, os escravos em geral do período no Brasil.

\subsection{3) A representação do vadio José da Fonseca}

A representação do vadio José da Fonseca revela-se aos poucos na peça. Por meio da interação com Aninha, o autor dá algumas pistas aos leitores/espectadores que a personagem não possui emprego e que não demonstra interesse em se casar com Aninha, uma vez que não possui muitos bens. Em termos de tratamento, a personagem caracteriza-se como um vadio nas conversas com Manuel João e o Juiz de Paz. Quando Manuel João interage com Maria Rosa, ele refere-se a José da Fonseca como um "vadio" e "melquitrefe", como consta nos excertos a seguir. Nos exemplos, José da Fonseca não está presente na cena:

Manuel João - Misericórdia! Minha filha fugir com um vadio daqueles! Eis, aí está o que fazem as rusgas do Rio Grande. Se não fosse o Rio Grande, não haviam recurutas e minha filha não fugiria com um deles.

(Cena 19, linhas 475- 477 do Anexo, p. 224)

Manuel João - Dê-me lá minha jaqueta e meu chapéu, que quero ir à casa do juiz de paz fazer queixa do que nos sucede. Hei-de mostrar àquele melquitrefe quem é Manuel João ... Vá, senhora, não esteja a choromingar.

(Cena 19, linhas 479- 481 do Anexo, p. 224)

Quando o Juiz interage com Manuel João, o Juiz também usa um tratamento injurioso para se referir a José da Fonseca ("bilitre"), mesmo com a presença deste último em cena no momento do ato interacional:

Juiz - Ah, então não é rebelião... Mas vossa filha casada com um bilitre destes?

(Cena 22, linha 544 do Anexo, p. 229) 
Além de ter sido já chamado de "bilitre", "melquitrefe" e "vadio", Manuel João também usa outros tratamentos durante uma simulação face a face entre José da Fonseca. Participam da cena o Juiz de Paz, Manuel João e José da Fonseca. A interação acontece quando este último é preso para ser recruta no Rio Grande do Sul, durante a Guerra dos Farrapos:

Manuel João - Sim, senhor. Mas, Sr. Juiz da paz, isto não podia ficar para amanhã? Hoje já é tarde, pode anoitecer no caminho e o sujeitinho escapulir.

(Cena 12, linhas 384- 385 do Anexo, p. 217)

No excerto dado, Manuel João se refere a José da Fonseca como "sujeitinho", ou seja, uma pessoa imprestável, reles, tal como registra o Houaiss. O uso do diminutivo, neste caso, aumenta ainda mais a injúria. Em outro momento, no entanto, Manuel João dispensa o diminutivo:

Manuel João - Não, porque era tarde e não queria que este sujeito fugisse no caminho.

(Cena 17, linhas 429- 430 do Anexo, p. 222)

Manuel João, no entanto, também usa um tratamento mais neutro com José da Fonseca, quando Manuel João está na presença do Juiz de Paz. Ele escolhe o tratamento "rapaz", que revela a pouca idade de seu interlocutor:

Manuel João - Sim senhor. Rapaz, acompanha-me. (Saem Manuel João e José.)

(Cena 12, linhas 392 do Anexo, p. 217)

No exemplo citado, há alteração na interlocução. O "Sim senhor" refere-se ao Juiz de Paz e "Rapaz" a José da Fonseca. Manuel João, assim, muda o foco da 
conversação. Em outra cena, Manuel João mantém o mesmo tratamento para com José da Fonseca diante do Juiz de Paz:

Manuel João - Este rapaz não pode ser soldado.

(Cena 22, linha 538 do Anexo, p.229)

No exemplo dado, Manuel João já sabia do casamento entre José da Fonseca e Aninha, fato que influencia também na forma de tratamento.

Em presença da família, quando Manuel João leva o recruta para casa por falta de cadeia, Manuel João o trata por "amigo", embora ele não mantenha uma relação amistosa com o seu interlocutor. Percebe-se, então, um tratamento irônico em relação a José da Fonseca:

Manuel João - Amenhã de madrugada. Este amigo dormirá trancado naquele quarto. Aonde está a chave?

(Cena 17, linhas 432-433 do Anexo, p. 222)

Manuel João - $\underline{\text { Amigo, }}$ venha cá. (Chega à porta do quarto e diz:) [...]

(Cena 17, linha 436 do Anexo, p. 222)

Além desses tratamentos, Manuel João usa o tratamento "você", que se caracteriza não só pela familiaridade, mas também nas relações de superior para inferior. Na posição de Guarda Nacional, ele possui autoridade diante de José da Fonseca, que foi pego para ser soldado. $O$ exemplo a seguir ilustra esse tipo de relação entre os dois: 
[...] Você ficará aqui até amenhã. Lá dentro há uma cama; faça o favor de entrar. (Entra, e M.João feicha a porta.) Bom, está seguro. Senhora, vamos para dentro contarmos quantas dúzias temos de bananas para levar amenhã pra cidade. A chave fica em cima da mesa; lembrem-me, se me esquecer. (Saem Manuel João e Maria Rosa.)

(Cena 17, linhas 436- 440 do Anexo, p. 222)

Após a notícia do casamento entre José da Fonseca e a filha, Manuel João usa o tratamento "você" e, em seguida, "senhor", equiparando-o em um tratamento de igual para igual e de respeito:

Manuel João - É preciso agora irmos dar parte ao juiz de paz que você já não pode ser soldado, pois está casado.Senhora, vá buscar minha jaqueta. (Sai Maria Rosa.) Então o senhor conta com o meu trabalho, não é assim?

(Cena 20, linhas 497- 499 do Anexo, p. 225)

Neste sentido, O Juiz de Paz também faz o mesmo em relação a José da Fonseca, quando sabe do casamento dele com Aninha. Ele inclusive pede desculpas de tê-lo ofendido de "bilitre" em outro momento da peça:

Juiz - A menina não perde ocasião! Agora, o que está feito está feito. O senhor não irá mais para a cidade, pois está casado. Assim, não falemos mais nisso. Já que estão aqui, hão-de fazer o favor de tomar uma xícara de café comigo, e dançarmos antes disto uma tirana. Vou mandar chamar mais algumas pessoas para fazerem a roda maior. (Chega à porta.) Ó Antônio! Vai à venda do Sr.Manuel do Coqueiro e dize aos senhores que há pouco saíram daqui que façam o favor de chegarem até cá. (Para José:) O senhor queira perdoar se o chamei de bilitre; já aqui não está quem falou.

(Cena 22, linhas 550- 557 do Anexo, p. 229-230)

Assim, embora vários tratamentos usados para com José da Fonseca tenham sido desvalorizantes de sua imagem, ele acaba adquirindo um status de respeito após o casamento com Aninha e sendo valorizado dentro da comunidade, pois ele pertence, agora, a uma família. 


\subsection{4) A representação do Juiz de Paz}

A partir da cena 9 na peça, o Juiz de Paz entra em cena. Como já mencionamos, trata-se de um ambiente formal de trabalho, mas as vestimentas do Juiz não correspondem à situação. Ele veste uma roupa simples, chinelas e não porta gravata, tal como demonstra a didascália a seguir:

Casa do Juiz de paz. Haverá uma mesa com alguns papéis; cadeiras. Entra o Juiz de paz vestido de calça branca, rodaque de riscado, chinelas verdes e sem gravata.

(Cena 9, linhas 214-215 do Anexo, p. 208)

A didascália já fornece um indício do contraste entre a imagem e a função social hierárquica que o Juiz estabelece em relação às outras personagens. Durante algumas cenas, o Juiz de Paz interage com os roceiros, exercendo a sua autoridade de juiz do local. Inicialmente, o Juiz de Paz recebe vários requerimentos das personagens roceiras para que ele tente solucionar cada problema apresentado pelas personagens. $\mathrm{Na}$ cena 9 , ele recebe o primeiro requerimento por meio de um escravo que, além de entregar uma carta, ainda lhe dá um presente: um cacho de bananas, como mostra o fragmento a seguir:

Juiz - Vamo-nos preparando para dar audiência hoje. (Arranja a mesa) O escrivão já tarda; sem dúvida está na venda do Manuel do Coqueiro ... O último recuruta que fizemos já me vai fazendo peso. Nada, não gosto de presos em casa. Podem fugir, depois dizem que o juiz de paz recebeu algum presente. (Batem na porta.) Quem é? Pode entrar. (Entra um negro com um caicho de bananas e uma carta, que entrega ao Juiz. Juiz, lendo a carta: ) "Ill. ${ }^{\text {mo }} \mathrm{Sr}$. - Muito me alegro de dizer a V.S . que a minha ao fazer desta é boa, e que a mesma desejo para $\underline{\text { V.S }}$. pelos circunlóquios com que lhe venero". (Deixando de ler:) Circunlóquios ... Que nome em breve! O que quererá ele dizer? Continuemos. (Lendo:) "Tomo a liberdade de mandar a $\underline{\mathrm{V} . \mathrm{S}}$ ‥ um caicho de bananas maçãs para $\underline{\mathrm{V} . \mathrm{S}^{\mathrm{a}} \text {. }}$ comer com a sua boca e dar também a comer à Sr.Juíza e aos Srs.Juizinhos. V.S $S^{a}$. há-de

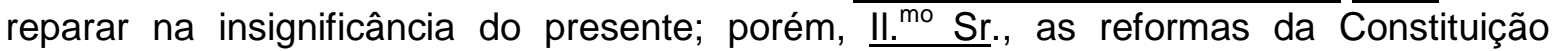
permitem a cada um fazer o que quiser, e mesmo fazer presentes; ora, mandando assim as ditas reformas, a $\underline{V} . S^{a}$. fará o favor de aceitar as ditas bananas, que diz minha Teresa Ova serem muito boas. No mais, receba as ordens de quem é seu venerador e tem a honra de ser- Manuel André de Sapiruruca." - Bom, tenho bananas para a sobremesa. Ó pai, 
leva estas bananas para dentro e entrega à senhora. Toma lá um vintém para teu tabaco. (Sai o negro.) O certo é que ser juiz de paz é bem bom. Nós temos de vez em quando nossos presentinhos, ora de farinha, ora de galinhas e etc. (Batem na porta.) Quem é?

(Cena 9, linhas 217-236 do Anexo, p. 208)

É importante salientar que o exemplo acima está estritamente relacionado à modalidade escrita, uma vez que se trata de uma carta dirigida a um juiz, ou seja, uma mensagem escrita para comunicar algo. Deve, assim, respeitar as normas linguísticas dessa característica textual, empregando uma linguagem adequada ao contexto. Visto que se trata de uma peça teatral e o público necessita saber o conteúdo do documento para a continuidade da ação, o Juiz deve ler a carta em voz alta durante a cena. $\mathrm{O}$ ato de ler, no texto escrito não oralizado no palco, fica expresso na didascália. O Juiz de Paz lê a carta e interrompe algumas vezes a leitura para fazer alguns comentários em relação ao conteúdo expresso por escrito.

Por se tratar de um texto estritamente escrito, encontramos formas de tratamento condizentes com este domínio discursivo, tais como "III. ${ }^{\mathrm{mo}} \mathrm{Sr}$. " e "V.S ${ }^{\mathrm{a}}$." . Estes tratamentos indicam respeito e distância, "Vossa Senhoria" é usado, sobretudo, para funcionários públicos e para correspondências cerimoniosas, tal como "llustríssimo Senhor". Há uma possível incoerência, no entanto, na organização textual da carta, uma vez que o autor da carta começa a escrever sobre um assunto sério, ao mesmo tempo em que oferece um "caicho" de banana para o Juiz e para a "Sr.Juíza" e aos "Srs. Juizinhos". Trata-se de uma incoerência pura e simples, condizente com o papel de um lavrador, levando em consideração a época e o local, a roça. O lavrador desconhece, assim, o sentido real da função do juiz, pois não deveria mencionar a esposa do Juiz e os filhos dele dessa maneira. 
Não é somente por esses elementos que percebemos a possível incoerência e a ignorância das personagens: Manuel André de Sapiruruca, o autor da carta e roceiro, tenta escrever de uma maneira mais rebuscada e o próprio juiz, que seria teoricamente uma pessoa letrada, não reconhece o significado da palavra "circunlóquios". Percebe-se a perspicácia do escritor ao mostrar as camadas rurais do século XIX na tentativa de usar o registro formal (texto escrito/requerimento) ao mesmo tempo em que consegue caracterizar a ingenuidade e os hábitos dessas camadas, inclusive pelo tratamento "Sr. Juíza" e "Sr.Juizinhos", o que ajuda a configurar o status das personagens roceiras.

No exemplo citado, Martins Pena nos dá algumas pistas da caracterização das duas personagens, tanto o roceiro quanto o Juiz de Paz são ignorantes. O Juiz gosta dos presentes e manda o escravo que está na cena entregar as bananas para uma senhora. Antes de ler a carta, há um indício na fala do Juiz de que é um hábito presenteá-lo e, parece que este tipo de ação não é bem vista por alguns, fato expresso pela indeterminação do sujeito do verbo "dizem": "Nada, não gosto de presos em casa. Podem fugir, depois dizem que o juiz de paz recebeu algum presente". O fato de ser presenteado na peça pode ser interpretado de duas maneiras: para os roceiros da peça, trata-se de um ato valorizante da imagem social do Juiz, visto que ele resolve os problemas das personagens e representa uma autoridade de respeito no local. Para o leitor/espectador, o fato de aceitar presentes pode caracterizar o Juiz como uma pessoa que aceita subornos para resolver os problemas, portanto, seria uma imagem desvalorizante da figura do Juiz de Paz.

$\mathrm{Na}$ cena 10, o Juiz recebe em seu local de trabalho outros roceiros, caracterizados de maneira humilde pelas didascálias, que descrevem as 
vestimentas. O Juiz mantém um tratamento respeitoso em relação a eles, com o uso de "senhores":

Juiz - Bom. Agora vamos-nos preparar a audiência. (Assentam-se ambos na mesa e o juiz toca a campainha.) Os senhores que estão lá fora no terreiro podem entrar. (Entram Inácio José e sua mulher, José da Silva, Francisco Antônio e Gregório, todos vestidos como roceiros; uns de jaqueta de chita, chapéu de palha, calças brancas de ganga, de tamancos, descalços; outros calçam os sapatos e meias quando entram, etc. Tomás traz um leitão debaixo do braço.) Está aberta a audiência. Os senhores que têm requerimentos para entregarem queiram-se aproximar.

(Cena 10, linhas 240- 247 do Anexo, p. 210)

Na cena 11, o Escrivão lê outros requerimentos para o Juiz de Paz e, tal como a carta, pertence à modalidade estritamente escrita, que a princípio não seria oralizada no palco, mas é preciso fazê-lo para a compreensão do andamento das ações. Trata-se de um documento escrito que contém uma reivindicação ou um pedido e que deve seguir as formalidades legais:

Escrivão, lendo - Diz Inácio José, natural desta freguesia e casado com Josefa Joaquina, sua mulher na face da Igreja, que precisa que Vossa Senhoria mande a Gregório degradado para fora da terra, pois teve o atrevimento de dar uma embigada em sua mulher, na encruzilhada do Pau-Grande, que quase a fez abortar, da qual embigada fez cair a dita sua mulher de pernas para o ar. Portanto pede a Vossa Senhoria mande o dito sujeito degradado para Angola. E.R.M.

(Cena 11, linhas 252-257 do Anexo, p. 211)

Tal como apontava a carta já lida pelo Juiz de Paz no outro exemplo já citado, o tratamento Vossa Senhoria prevalece na escrita, embora novamente o conteúdo do requerimento não obedeça às formalidades dessa modalidade de texto. Para finalizar o requerimento, Inácio José termina com "Espera Receber Mercê" (E.R.M), uma antiga fórmula de encerramento para petições e que se encontra em desuso na língua portuguesa brasileira atual. Para dirigir-se ao acusado, o Juiz usa um 
tratamento respeitoso, "Sr." acompanhado pelo prenome do indivíduo, Gregório e para se referir à envolvida no caso, "senhora":

Juiz - É verdade, Sr.Gregório, que o senhor deu uma embigada na senhora?

(Cena 11, linha 258 do Anexo, p. 211)

Como resposta, Gregório mantém um tratamento respeitoso com o Juiz de Paz, chamando de "Sr." acompanhado de sua função profissional. Gregório, no entanto, refere-se à mulher envolvida na acusação de "bruxa", tratamento injurioso e desrespeitoso:

Gregório - É mentira, Sr.Juiz da paz, eu não dou embigadas em bruxas.

(Cena 11, linhas 259 do Anexo, p. 211)

A envolvida, Josefa Joaquina, refere-se a Gregório como "malcriado" e, além disso, retribui a injúria para seu interlocutor, atingindo a sua família, no caso, a mulher de Gregório, referindo-a de "bruxa" e "marafona":

Josefa Joaquina - Bruxa é a marafona de tua mulher, malcriado! Já não se lembra que me deu uma embigada, e que me deixou uma marca rouxa na barriga? Se o senhor quer ver, eu posso mostrar.

(Cena 11, linhas 260-262 do Anexo, p. 211)

$\mathrm{Na}$ mesma fala de Josefa Joaquina, ela dirige-se ao Juiz de maneira respeitosa, com o uso de "senhor". Na continuidade da interação, ela mantém o tratamento e acrescenta a função profissional, "Sr.juiz". Para referir-se a Gregório, ela usa o tratamento "este homem", um tratamento de familiaridade e se refere a Inácio José com o possessivo "meu marido": 
Josefa Joaquina - $\underline{\operatorname{Sr}}$. juiz, não é a primeira embigada que este homem me dá; eu é que não tenho querido contar a meu marido.

(Cena 11, linhas 264-265 do Anexo, p. 211)

O Juiz pede calma para Josefa Joaquina e a trata por "senhora", mantendo um tratamento respeitoso e distante em relação a sua interlocutora. Em relação a Inácio José e Gregório, ele trata ambos por "Sr." mais o nome próprio:

Juiz - Está bom, senhora, sossegue. Sr.Inácio José, deixe-se destas asneiras, dar embigadas não é crime classificado no Código. Sr.Gregório, fará o favor de não dar mais embigadas na senhora; quando não arrumo-lhe com as leis às costas e meto-o na cadeia.Queiram-se retirar.

(Cena 11, linhas 266-269 do Anexo, p. 211)

Diante da não solução do caso por parte do Juiz de Paz, Inácio José ameaça Gregório e usa o tratamento "tu”, que indica proximidade com seu interlocutor:

Inácio José, para Gregório - Lá fora tu me pagarás.

(Cena 11, linha 270 do Anexo, p. 212)

A cena tem continuidade com a leitura de outro requerimento e, seguindo os exemplos dos anteriores na peça, seguem-se os mesmos tratamentos "Vossa Senhoria" e "Ilustríssimo Senhor", com a fórmula de encerramento "Espera Receber Mercê". Tal como nos outros exemplos, o requerimento possui uma queixa banal e conteúdo informal não condizente com este tipo de modalidade escrita. É compreensível, no entanto, que isso foi feito de maneira proposital por Martins Pena para demonstrar a ingenuidade dos roceiros perante o Juiz de Paz no mundo rural da época: 
Escrivão, lendo - "O abaixo-assinado vem dar os parabéns a $\underline{\mathrm{V}} . \mathrm{S}^{\mathrm{a}}$. por ter entrado com saúde no novo ano financeiro. Eu, $\underline{l}{ }^{\mathrm{mo}} \mathrm{Sr}$. Juiz da paz, sou senhor de um sítio que está na beira do rio, aonde dá muito boas bananas e laranjas, e como vem a encaixe, eu peço a $\underline{\text { V.S }}$ o favor de aceitar um cestinho das ditas que mandarei hoje à tarde. Mais, como ia eu dizendo, o dito sítio foi comprado com o dinheiro que minha mulher ganhou nas costuras e noutras coisas mais; e, vai senão quando, um meu vizinho, homem da raça do Judas, diz que metade do sítio lhe pertence. E então, que lhe parece, Sr.Juiz, não é desaforo? Mais, como ia dizendo, peço a $\underline{\mathrm{V} . \mathrm{S}}$. para vir assistir à marcação do sítio. Manuel André. E.R.M."

(Cena 11, linhas 273-281 do Anexo, p. 212)

Após a leitura do requerimento, o Juiz de Paz recusa-se a deferir o pedido, o que ocasiona revolta por parte do requerente. Apesar da revolta, ele mantém um tratamento respeitoso em relação ao Juiz de Paz, como o uso de "Sr.":

Juiz - Não posso deferir por estar muito atravancado com um roçado; portanto, requeira ao suplente, que é o meu compadre Pantaleão.

Manuel André - Mais, Sr.Juiz, ele tãobém está ocupado com uma plantação.

(Cena 11, linha 282-284 do Anexo, p. 212)

Diante da argumentação de Manuel André, o Juiz irrita-se com o seu interlocutor e, pela primeira vez, muda o tratamento para "você", uso que destaca a sua autoridade, uma vez que "você" é usado também no tratamento de superior para inferior na época. Não bastasse a mudança de tratamento, é clara a ameaça do Juiz de Paz diante de seu interlocutor, ameaçando-o colocar na cadeia:

Juiz - Você replica? Cadeia, cadeia!

(Cena 11, linhas 285 do Anexo, p. 212) 
Apesar da ameaça, Manuel André não se sente intimidado. Ele responde de maneira polida com o tratamento de "Vossa Senhoria" e conta com o argumento de que não é possível prendê-lo com base na Constituição:

Manuel André - Vossa Senhoria não pode prender-me à toa: a Constituição não manda.

(Cena 11, linhas 286-287 do Anexo, p. 212)

O Juiz de Paz, ciente do conhecimento de leis de seu interlocutor, sente-se ameaçado em sua posição de autoridade mais uma vez e se coloca em uma posição de autoridade máxima, em que ele tem o poder de derrogar a Constituição e, assim, é possível prender seu interlocutor. O Juiz ainda usa o tratamento "este homem", colocando-o ainda mais em uma posição inferior:

Juiz - A Constituição! ... Está bem! ... Eu, o Juiz de paz, hei por bem derrogar a Constituição! Sr. Escrivão, tome termo que a Constituição está derrogada, e mande-me prender este homem.

(Cena 11, linhas 288- 290 do Anexo, p. 212)

Manuel André ainda discute com o Juiz de Paz e diante da teimosia de seu interlocutor, o Juiz passa para a agressão verbal por meio de um termo depreciativo: "Brejeiro", desvalorizando-o. Além da agressão verbal, o Juiz de Paz vai atrás de Manuel André, atitude expressa pela didascália, que corre diante do ocorrido. O Juiz tenta alcançá-lo:

Juiz, levantando-se - Brejeiro! ... (Manuel André corre; o Juiz vai atrás.) Pega ... Pega ... Lá se foi....Que leve o diabo. (Assenta-se.) Vamos às outras partes.

(Cena 11, linhas 294-295 do Anexo, p. 213) 
Na mesma cena 11, ocorre outro momento de interação entre o Juiz e outra personagem roceira. Após a leitura de outro requerimento, cujo modelo segue os mesmos exemplos anteriores em termos de tratamento e de conteúdo, o Juiz ameaça colocar José da Silva na cadeia, caso não obedeça à ordem do juiz. Ele argumenta algumas possibilidades para reverter a posição do Juiz diante do caso e, com a insistência em não ceder à decisão do Juiz, José da Silva sofre ameaça. O Juiz o trata por "este rebelde" e o manda agarrar para ser soldado. Diante da intimidação, José da Silva mostra-se flexível e aceita a decisão tomada pelo Juiz, mostrando-Ihe humildade, como demonstra a didascália "com humildade" referenciada no exemplo que segue. Em uma posição humilde, ele valoriza a figura de autoridade do Juiz de Paz. Além disso, ele mantém um tratamento cortês desde o início da interação, com o uso de "Sr.Juiz" e "Vossa Senhoria":

Juiz - Terá a bondade de entregar o filho a seu dono, pois é aqui da mulher do senhor. José da Silva - Mas, Sr.Juiz..... Juiz - Nem mais nem meio mas; entregue o filho, senão, cadeia. José da Silva - Eu vou queixar-me ao Presidente.

Juiz - Pois vá, que eu tomarei apelação.

José da Silva - E eu embargo.

Juiz - Embargue ou não embargue, embargue com trezentos mil diabos, que eu não concederei revista no auto do processo!

José da Silva - Eu lhe mostrarei, deixe estar.

Juiz- Sr. Escrivão, não dê anistia a este rebelde, e mande-o agarrar para soldado.

José da Silva, com humildade - Vossa Senhoria não se arrenegue! Eu entregarei o pequira.

(Cena 11, linhas 360-372 do Anexo, p. 215-216)

Em outra cena, na 21, o Juiz de Paz está novamente com o Escrivão. É nesta cena que confirmamos o fato de que o Juiz de Paz não possui as qualidades necessárias de um juiz para exercer o cargo. Ele confessa ao escrivão que irá se aconselhar com um letrado, para espanto do funcionário. Embora o Juiz tenha confessado que não possui conhecimento para exercer a sua profissão, o Escrivão 
mantém ainda assim um tratamento respeitoso, com o uso de "Vossa Senhoria" na interação face a face com o Juiz:

Escrivão - Vossa Senhoria vai amenhã à cidade?

Juiz - Vou, sim. Quero-me aconselhar com um letrado para saber como hei-de despachar alguns requerimentos que cá tenho.

Escrivão - Pois Vossa Senhoria não os sabe despaichar?

Juiz - Eu? Ora essa é boa ! Eu entendo cá disso? Ainda quando é algum caso de embigada, passa; mas casos sérios, é outra coisa. [...]

(Cena 21, linhas 513-518 do Anexo, p.227)

Na cena 22 e na última cena, o Juiz está ciente do casamento de Aninha com José da Fonseca. O Juiz decide reunir todos os roceiros que apareceram em cena para comemorar a novidade. O Juiz ora usa um tratamento amistoso como "os amigos", ora usa também tratamentos de respeito, tais como "minha senhora" e "meus senhores" para os roceiros:

Juiz - Obrigado, minha senhora... Aí chegam os amigos.

(Cena 22, linha 563 do Anexo, p. 230)

Juiz - Sejam bem-vindos, meus senhores. (Comprimentam-se.) Eu os mandei chamar para tomarem uma xícara de café comigo e dançarmos um fado em obséquio ao sr.Manuel João, que casou sua filha hoje.

(Cena Última, linhas 566- 568 do Anexo, p. 231)

Juiz - Sr. Escrivão, faça o favor de ir buscar a viola. (Sai o Escrivão.) Não façam ceremônia; suponham que estão em suas casas. Haja liberdade. Esta casa não é agora do juiz de paz é de João Rodrigues. Sr.Tomás, faz-me o favor? (Tomás chega-se para o Juiz e este o leva para um canto.) O leitão ficou no chiqueiro?

(Cena Última, linhas 573- 577 do Anexo, p. 231)

No último exemplo, o Juiz de Paz equipara-se aos outros roceiros, atitude expressa pela fala "Não façam ceremônia; suponham que estão em suas casas. Haja liberdade. Esta casa não é agora do juiz de paz - é de João Rodrigues". Ele, inclusive, revela a sua identidade neste momento: chama-se João Rodrigues. Essa mudança de comportamento se evidencia após a revelação de que ele não possuía 
conhecimento para o cargo de juiz e de que era necessário consultar um letrado. Após a revelação, a "máscara do Juiz cai", de forma a configurá-lo em uma personagem desprovida de autoridade, de respeito e caracterizando-o, assim, como uma personagem simples e humilde como as demais personagens roceiras.

\subsection{5 ) A representação do Escrivão}

O Escrivão, cuja personagem é designada apenas pela sua função e não lhe é atribuído nome, aparece em cena para seguir as ordens do Juiz de Paz, ou seja, convocar um Guarda Nacional para levar um recruta à cidade. Neste caso, o guarda em questão é Manuel João, com quem o Escrivão mantém um tratamento respeitoso. Para entrar na casa de Manuel João, o Escrivão usa o tratamento formal e respeitoso: "Sr." acompanhado do nome próprio:

Escrivão do Juiz - Dá licença, Sr. Manuel João?

(Cena 5, linha 146 do Anexo, p. 203)

Manuel João responde ao Escrivão mantendo o mesmo tratamento respeitoso:

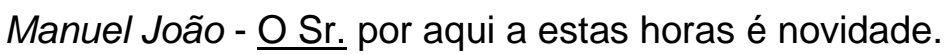

(Cena 5, linhas 154 do Anexo, p. 203)

Em seguida, o Escrivão interage com a mesma personagem e esclarece 0 motivo de sua visita inesperada:

Escrivão - Venho da parte do senhor juiz de paz intimá-lo para levar um recuruta à cidade.

(Cena 5, linhas 155-156 do Anexo, p. 203) 
Manuel João recusa a sua intimação, usando um tratamento com função de vocativo, "Ó homem", indicativo de familiaridade:

Manuel João - Ó homem, não há mais ninguém que sirva para isto?

(Cena 5, linha 157 do Anexo, p. 203)

Diante da recusa de Manuel João em exercer a função de levar um soldado à cidade, o Escrivão procura um tratamento mais amistoso com a personagem: "Meu amigo", em função de vocativo. Não bastasse o tratamento mais cordial em relação a Manuel João, ele também usa o pronome sujeito "vós", que na época já estava caindo em desuso, mas reservava-se em situações de extrema polidez em relação ao interlocutor:

Escrivão - Meu amigo, isto é pouco patriotismo. Vós bem sabeis que é preciso mandar gente para o Rio Grande; quando não podemos perder esta província.

(Cena 5, linhas 161-162 do Anexo, p. 203)

Diante da teimosia de Manuel João em não aceitar o ofício, o Escrivão retoma o mesmo tratamento amistoso para convencê-lo: "meu amigo"

Escrivão - Mas, meu amigo, os rebeldes têm feito por lá horrores, e é preciso que sejam castigados.

(Cena 5, linhas 165-166 do Anexo, p. 203)

Novamente, Manuel João recusa e adota um tratamento mais distante e polido com o Escrivão, "o senhor". Ao mesmo tempo, Manuel João adota um tom revoltado com seu interlocutor, expresso pelo conteúdo de sua fala e pelo uso de várias exclamações: 
Manuel João - E o que quer o senhor que se lhe faça? Ora essa é boa! Castigados precisam ser aqueles que foram causa de tudo isto. Ora não é má esta! Um pobre lavrador como eu ver-se obrigado a perder um dia de trabalho por causa do Rio Grande, ao mesmo tempo que aqueles que foram causa estão de perninhas a ganharem dinheiro. Não se dá maior patifaria! Ora esta!

(Cena 5, linhas 167-171 do Anexo, p. 203)

Apesar de todas as tentativas amistosas por parte do Escrivão, Manuel João se mantém irredutível, o que faz o Escrivão, zangado, ameaçá-lo de prisão e exercer a sua autoridade com o respaldo do Juiz de Paz:

Escrivão, zangado - Tenha paciência, o senhor juiz manda-lhe dizer que se não comparecer, irá preso.

(Cena 5, linhas 172-173 do Anexo, p. 204)

O Escrivão usa a voz do Juiz de Paz, que representa a autoridade e a força da lei, para intimar Manuel João novamente. Após a ameaça, Manuel João aceita levar o soldado para a cidade e, sendo assim, o Escrivão retoma o tratamento cortês até então dispensado para Manuel João, expresso pelos possessivos "vossas" e "vossos". O uso de "vossas" e "vossos" também pode ser interpretado como uma referência à toda família de Manuel João, visto que Maria Rosa e Aninha estão presentes na cena, embora não participem do ato interacional:

Escrivão, à parte - Em boa o diga. (À parte) Custou-me achar um guarda. Apre! Às vossas ordens.

(Cena 5, linhas 175-176 do Anexo, p. 204)

Escrivão - Sentido nos vossos cães.

(Cena 5, linhas 178 do Anexo, p. 204) 
Manuel João, por sua vez, mantém o mesmo respeito pelo Escrivão e também utiliza o possessivo "vossas" em sua resposta:

Manuel João - Às vossas ordens.

(Cena 5, linhas 177 do Anexo, p. 204)

Até então, focalizamos os tratamentos das personagens Manuel João e Escrivão, mas este último interage na mesma cena com Maria Rosa e Aninha, que estão presentes no ato interacional no momento em que o Escrivão adentra a casa de Manuel João, momento em que o núcleo familiar cruza com o núcleo laboral. Para cumprimentá-las, o Escrivão mantém um tratamento cortês e polido em relação às duas mulheres:

Escrivão (entrando) - Deus esteja nesta casa.

Manuel João - Amém.

Escrivão - Um criado da Senhora Dona e da Senhora Doninha.

(Cena 5, linhas 150-152 do Anexo, p. 203)

Por meio do tratamento "Senhora Dona" e "Senhora Doninha", ele expressa respeito em relação as duas e, ao mesmo tempo, um tratamento distante. Em relação às mulheres, elas adotam um tratamento de submissão para com o Escrivão:

Maria Rosa e Aninha - Uma sua criada (fazem uma mesura)

(Cena 5, linhas 153 do Anexo, p. 203)

O ato de fazer uma mesura as coloca em uma posição de reverência e submissão diante do Escrivão, valorizando a imagem social deste último. 
Ao despedir-se de todos da casa, o Escrivão mantém o mesmo tratamento distante já utilizado: "Senhora Dona":

Escrivão - Senhora Dona, passe bem.

(Cena 5, linhas 180 do Anexo, p. 204)

É importante, salientar, no entanto, que boa parte das interações do Escrivão se dá no ambiente de trabalho, onde ele recebe as ordens do Juiz de Paz. Predominantemente, o Juiz de Paz usa "Sr.", seguido da função profissional, "Escrivão":

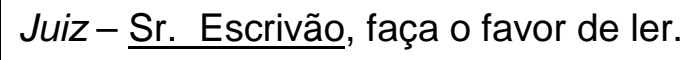

(Cena 11, linha 251 do Anexo, p. 211)

Juiz - Estão conciliados. (Inácio José, Gregório e Josefa Joaquina saem.) Sr . Escrivão, faça o favor de ler o outro requerimento.

(Cena 11, linhas 271-272 do Anexo, p. 212)

Juiz - Sr. Escrivão, chame o meirinho. (Os dois apartando-se.) Espere, Sr. Escrivão, não é preciso. (Assenta-se.) [...]

(Cena 11, linhas 317- 318 do Anexo, p. 213)

Juiz - Está bom, veremos o que poderei fazer. Queiram-se retirar. Estão conciliados ; tenho mais que fazer. (Saem os dois.) Sr. Escrivão, faça o favor de ... [...]

(Cena 11, linhas 344- 345 do Anexo, p. 215)

Juiz, assentando-se - Era muito capaz de se esquecer. Sr. Escrivão, leia o outro requerimento.

(Cena 11, linhas 349-350 do Anexo, p. 215)

Juiz- Sr. Escrivão, não dê anistia a este rebelde, e mande-o agarrar para soldado.

(Cena 11, linhas 370 do Anexo, p. 216)

Juiz, com as galinhas nas mãos - Ao menos com esta visita lucrei. Sr. Escrivão, veja como estão gordas! Levam a mão abaixo. Então, que diz?

(Cena 15, linhas 408-409 do Anexo, p. 220) 
Juiz- Oh, uma rebelião? Sr. Escrivão, mande convocar a Guarda Nacional e oficie ao Governo.

(Cena 22, linhas 539-540 do Anexo, p. 229)

Juiz - Sr. Escrivão, faça o favor de ir buscar a viola. (Sai o Escrivão.) Não façam ceremônia; suponham que estão em suas casas. Haja liberdade. Esta casa não é agora do juiz de paz - é de João Rodrigues. Sr.Tomás, faz-me o favor? (Tomás chega-se para o Juiz e este o leva para um canto.) O leitão ficou no chiqueiro?

(Cena Última, linhas 573-576 do Anexo, p. 231)

Juiz - [ ...] Os outros senhores abanquem-se.... Sr.Escrivão, ou toque, ou dê a viola a algum dos senhores. Um fado bem rasgadinho ....bem choradinho ...

(Cena Última, linhas 580-582 do Anexo, p. 231)

Há apenas uma ocorrência, no entanto, em que o Juiz de Paz usa somente "senhor", momento que o Escrivão descobre que o Juiz de Paz não possui todos os conhecimentos necessários para exercer a sua profissão, pois não sabe despachar:

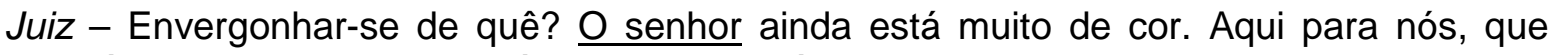
ninguém nos ouve, quantos juízes de direito há por estas comarcas que não sabem aonde têm sua mão direita, quanto mais juízes de paz ... E além disso, cada um faz o que sabe. (Batem.) Quem é?

(Cena 21, linhas 527- 530 do Anexo, p. 227-228)

Quando o Escrivão não interage diretamente com o Juiz de Paz, este último prefere apenas nomeá-lo pela sua função, "escrivão":

Juiz - Ah, é o escrivão. Pode entrar.

(Cena 9, linhas 238 do Anexo, p. 209)

Juiz - Vamo-nos preparando para dar audiência hoje. (Arranja a mesa) O escrivão já tarda; sem dúvida está na venda do Manuel do Coqueiro ... [...]

(Cena 9, linhas 217-218 do Anexo, p. 208)

As escolhas tratamentais em relação ao Escrivão revelam o respeito de outras personagens em relação à sua imagem social, respeito inclusive de seu 
superior, o Juiz de Paz. Ele exerce a sua autoridade tal como o Juiz de Paz, mas não possui "máscara". A imagem social do Escrivão é construída durante a interação, mas, diferentemente do Juiz de Paz, a imagem do Escrivão não é desconstruída e sim mantida até o fim da comédia.

\subsection{Aspectos fonológicos na peça O Juiz de Paz da roça}

Fenômenos fonéticos representativos de discurso oral, popular, de uso informal são encontrados na peça $O$ Juiz de Paz da roça.

Vários desses fenômenos chamam a atenção no diálogo da peça. Um dos exemplos é o uso do verbo "pretender", por exemplo. Aninha e Manuel João, ambos roceiros, usam a forma "pertender" por metátese, forma que o povo ainda usa. Salienta-se que, no entanto, na época de Martins Pena concorriam as formas "pretender" e "pertender".

Nascentes (1953) realizou um importante estudo das alterações sofridas no português brasileiro, em especial no linguajar carioca no ano de 1922. Segundo o referido pesquisador, era muito comum o fenômeno da metátese na classe inculta, pois se evitavam esforços articulatórios inúteis. Era um fenômeno comum na época, mas continua presente no discurso oral nos dias de hoje. Os exemplos a seguir destacam o fenômeno da metátese nas falas de Aninha e Manuel João, ambos roceiros e que compartilham o mesmo local de habitação:

Aninha - Quando é que você pertende casar-se comigo, para podermos ir para corte?

(Cena 2, linhas 81-82 do Anexo, p.199)

Manuel João - Obrigado (bebendo a jacuba). Hoje trabalhei como gente... Limpei o mandiocal que estava muito sujo.... fiz uma derrubada do lado de Francisco Antônio .... e abri uma vala para esgotar as águas que estavam fazendo o feijão apodrecer... e hoje à 
tarde pertendo colher um pouco de café... Aninha?

(Cena 5, linhas 115-118 do Anexo, p. 202)

Outro fenômeno interessante acontece novamente na fala de Manuel João. Ele usa a palavra "corgo" por haplologia em vez de "córrego". A forma "corgo" encontra-se, por exemplo, dicionarizada. Em seu estudo, Nascentes (1953) salienta também que este fenômeno se dá na classe inculta.

Manuel João - Pois que coma laranja com farinha, ele não é melhor do que eu. Diabo! um dia destes eu ... Diabo de carne! ... hei-de fazer uma plantação ... Lá se vão os dentes!... Deviam ter botado esta carne de molho no corgo .... Que diabo de laranjas tão azedas! (Batem na porta) Quem é? (Logo que Manuel João ouve bater na porta, esconde os pratos na gaveta e lambe os dedos.)

(Cena 5, linhas 141-145 do Anexo, p. 203)

Em termos de alterações fonéticas, o "a”, por exemplo, pode se transformar em um "e" reduzido ou fechado, dependendo dos fonemas vizinhos. Em O Juiz de Paz da roça, ora ocorre a forma "amenhã", ora "amanhã", mas temos sobretudo o predomínio de "amenhã".

Nascentes (1953) afirma que as vogais átonas costumam sofrer várias transformações que variam do enfraquecimento até a supressão. Sobre a forma "amenhã" e "menhã", o referido pesquisador considerava na época um arcaísmo preservado e, se levarmos em consideração que se trata realmente de um arcaísmo, geralmente as comunidades mais afastadas da área urbana mantêm alguns traços arcaizantes na linguagem, devido ao afastamento com outras comunidades de fala. Encontramos esse fenômeno nas falas de Aninha, José da Fonseca, Manuel João, Maria Rosa e na fala do Escrivão a seguir: 
Aninha - Então amenhã de menhã.

(Cena 2, linha 84 do Anexo, p.199)

José da Fonseca - Adeus, até amenhã de menhã.

(Cena 2, linha 87 do Anexo, p.199)

Manuel João, entrando - Estou fardado. Adeus, senhora, até amenhã. (Dá um abraço.)

(Cena 7, linhas 200-201 do Anexo, p. 206)

Maria Rosa - Bota aí no chão, para amenhã ir pra o sol.

(Cena 16, linha 417 do Anexo, p. 221)

Manuel João - Amenhã de madrugada. Este amigo dormirá trancado naquele quarto. Aonde está a chave?

(Cena 17, linhas 432-433 do Anexo, p. 222)

Manuel João - Amigo, venha cá. (Chega à porta do quarto e diz:) Você ficará aqui até amenhã. [...] Senhora, vamos para dentro contarmos quantas dúzias temos de bananas para levar amenhã pra cidade. A chave fica em cima da mesa; lembrem-me, se me esquecer. (Saem Manuel João e Maria Rosa.)

(Cena 17, linhas 436-440 do Anexo, p. 222)

Escrivão - Vossa Senhoria vai amenhã à cidade?

(Cena 21, linha 513 do Anexo, p. 227)

Manuel João - Eu o tinha preso em meu quarto para levá-lo amenhã para a cidade; porém a menina, que foi mais esperta, furtou-me a chave e fugiu com ele.

(Cena 22, linhas 545-546 do Anexo, p. 229)

Embora haja o predomínio da forma "menhã" (duas ocorrências) ou "amenhã" (nove ocorrências), verificamos duas ocorrências no texto do uso de "manhã", forma que permanece nos dias de hoje. Encontramos o fenômeno em uma fala de Maria Rosa enquanto ela interage com Aninha e em outra fala de Manuel João, quando ele interage com o Juiz de Paz:

Maria Rosa - Pobre homem! ... Ele mata-se em trabalhar!. É quase meio dia e ainda não voltou para casa! Desde as quatro horas da manhã que ele saiu, está só com uma chicra de café. 
(Cena 1, linhas 6-8 do Anexo, p. 197)

Manuel João - Sim, senhor. Mas, Sr. Juiz da paz, isto não podia ficar para amanhã? Hoje já é tarde, pode anoitecer no caminho e o sujeitinho escapulir.

(Cena 12, linhas 384-385 do Anexo, p. 217)

No mesmo exemplo dado, a fala de Maria Rosa se destaca por outro fenômeno: a síncope da palavra "xícara", "chicra", comum na fala popular, inclusive ainda nos dias de hoje. No texto, além da alteração fonética, ocorre também uma alteração ortográfica. Em uma fala do Juiz de Paz, verificamos, no entanto, o uso da forma "xícara":

Juiz - Sejam bem-vindos, meus senhores. (Comprimentam-se.) Eu os mandei chamar para tomarem uma xícara de café comigo e dançarmos um fado em obséquio ao Sr.Manuel João, que casou sua filha hoje.

(Cena Última, linhas 566-568 do Anexo, p. 231)

Embora tenha ocorrido uma diferença de uso de "chicra" e "xícara" por parte de Maria Rosa (roceira) e pelo Juiz de Paz, não podemos afirmar que esses usos os caracterizam socialmente, visto que há somente uma ocorrência das duas formas.

Além de todos esses fenômenos levantados, há também o uso de "recuruta" em vez de "recruta", por suarabácti. Nascentes (1953) sustenta que é comum esse fenômeno entre os grupos com / e com $r$, sobretudo para facilitar a pronúncia de algumas palavras:

Escrivão - Venho da parte do senhor juiz de paz intimá-lo para levar um recuruta à cidade.

(Cena 5, linhas 155-156 do Anexo, p. 203)

Juiz - Vamo-nos preparando para dar audiência hoje. (Arranja a mesa) O escrivão já tarda; sem dúvida está na venda do Manuel do Coqueiro ... O último recuruta que fizemos já me vai fazendo peso. [...]

(Cena 9, linhas 217-219 do Anexo, p. 208)

Juiz - Aqui está o recuruta que deve levar para cidade. Deixe-o no quartel do Campo de Santana e vá levar esta parte ao general. (Dá um papel.) 
(Cena 12, linhas 382-383 do Anexo, p. 217)

José da Fonseca - Assim que botei os pés fora desta porta, encontrei com o juiz de paz, que me mandou prender para recuruta.

(Cena 18, linhas 447-448 do Anexo, p. 223)

Manuel João - Misericórdia! Minha filha fugir com um vadio daqueles! Eis, aí está o que fazem as rusgas do Rio Grande. Se não fosse o Rio Grande, não haviam recurutas e minha filha não fugiria com um deles.

(Cena 19, linhas 475- 477 do Anexo, p. 224)

É interessante observar que o fenômeno ocorre tanto nas falas dos roceiros quanto na fala das autoridades, como o Escrivão e o Juiz de Paz.

Exemplo semelhante com o mesmo fenômeno ocorre com a palavra "bilitre", em que acrescentamos o "i" entre o "l" e o "t" da palavra "biltre", fenômeno que acontece em duas falas do Juiz de Paz:

Juiz - Ah, então não é rebelião... Mas vossa filha casada com um bilitre destes?

(Cena 22, linhas 544 do Anexo, p. 229)

Juiz - A menina não perde ocasião! Agora, o que está feito está feito. O senhor não irá mais para a cidade, pois está casado [...]. (Para José:) O senhor queira perdoar se o chamei de bilitre; já aqui não está quem falou.

(Cena 22, linhas 550-557 do Anexo, p. 229-230)

Vários fenômenos destacam-se ainda no texto. A metafonia também se faz presente nas falas das personagens. Encontramos no texto o uso de "entanhas" em vez de "intanhas" em uma fala de Aninha por metafonia:

Aninha, só - Como é bonita a corte! Lá é que a gente pode se divertir e não aqui aonde não se ouve senão os sapos e as entanhas cantarem! Teatros, mágicas, cavalos que dançam, cabrito com duas cabeças, quanta coisa! Eu quero ir para Corte.

(Cena 3, linhas 90-93 do Anexo, p. 200) 
A palavra "intanha" é encontrada nos dicionários, porém não há o registro de "entanha". Neste sentido, também há o uso de "samburá" e "samborá" no texto. A primeira forma encontra-se em uma fala de Maria Rosa para Aninha e a segunda forma em uma didascália, texto escrito que não é oralizado em cena:

Manuel João - Quando acabares de jantar, pega em um samburá, e vai colher o café dos cafezeiros que estão à roda da casa.

(Cena 5, linhas 120-121 do Anexo, p. 202)

Casa de Manuel João. Entram Maria Rosa e Aninha com um samborá na mão.

(Cena 16, linha 412 do Anexo, p. 221)

O dicionário Houaiss registra apenas "samburá", mas consta na etimologia da palavra a forma "samborá", com a data de 1842.

Um exemplo parecido ocorre com a palavra "incombido" usado no texto com o sentido de "incumbido" na cena 18, na fala de José da Fonseca:

José da Fonseca - E se teu pai não fosse incombido de me levar, estava perdido, havia de sentar praça.

(Cena 18, linhas 450-451 do Anexo, p. 223)

Exemplo semelhante se dá também com o verbo "cumprimentar", usado no texto como "comprimentar" em uma das falas de Aninha com José da Fonseca, nas didascálias das cenas 22 e da última cena:

Aninha - Deixemo-nos de comprimentos. Ora diga-me, como foi o senhor preso?

(Cena 18, linha 446 do Anexo, p. 223)

Juiz - Senhora Dona, queira perdoar se ainda a não cortejei. (Comprimenta.)

Maria Rosa, comprimentando - Uma criada de Sua Excelência.

(Cena 22, linhas 561-562 do Anexo, p. 230) 
Juiz - Sejam bem-vindos, meus senhores. (Comprimentam-se.) Eu os mandei chamar para tomarem uma xícara de café comigo e dançarmos um fado em obséquio ao Sr.Manuel João, que casou sua filha hoje.

(Cena Última, linhas 566-568 do Anexo, p. 231)

Por fim, outro exemplo de metafonia no texto se dá com a palavra "ceremônia" em vez de "cerimônia" na última cena na fala do Juiz. Destaca-se que a forma "cerimônia" também aparece na peça, mas em um documento escrito redigido por um roceiro na cena 11. A seguir, os dois exemplos na peça:

Juiz - Sr. Escrivão, faça o favor de ir buscar a viola. (Sai o Escrivão.) Não façam ceremônia; suponham que estão em suas casas. Haja liberdade. Esta casa não é agora do juiz de paz - é de João Rodrigues. Sr.Tomás, faz-me o favor? (Tomás chega-se para o Juiz e este o leva para um canto.) O leitão ficou no chiqueiro?

\section{(Cena Última, linhas 573- 576 do Anexo, p. 231)}

Escrivão, lendo - Diz João de Sampaio que, sendo ele "senhor absoluto de um leitão que teve a porca mais velha da casa, aconteceu que o dito acima referido leitão furasse a cerca do Sr.Tomás pela parte de trás, e com a sem - cerimônia que tem todo o porco, fossasse a horta do mesmo senhor. Vou a respeito de dizer, Sr. Juiz, que o leitão, carece agora advertir, não tem culpa, porque nunca vi um porco pensar como um cão, que sempre é mais alguma coisa e pensa às vezes como o melhor homem. Para V.Sa . não pensar que minto, Ihe conto uma história: a minha cadela Tróia, aquela mesma que escapou de morder a V.S . naquela noite, depois que lhe dei uma tunda nunca mais comeu na cuia com os pequenos. Mas vou a respeito de dizer que o Sr.Tomás não tem ração em querer ficar com o leitão só porque comeu três ou quatro cabeças de nabo.Assim, peço a V.Sํ. que mande entregar-me o leitão. E.R.M."

(Cena 11, linhas 296-307 do Anexo, p. 213)

Outro fenômeno encontrado no texto por transformação é a dissimilação. No texto, trata-se da palavra "pequira", que se encontra registrada no dicionário com datação de 1826, para a palavra "piquira":

José da Silva, com humildade - Vossa Senhoria não se arrenegue! Eu entregarei o pequira. 
Alterações fonéticas se fazem presente ainda no texto em vários momentos. A forma "Abenção", proferida por Aninha em várias cenas, é uma expressão informal segundo Houaiss, pois a forma correta indicada pelo dicionário é "bênção". A forma "abenção" seria uma forma proveniente da junção entre o artigo "a" ao substantivo "benção". Em frases do tipo "Dê-me a bênção", a palavra acabou se constituindo um só vocábulo fonético na língua do povo, pelo fenômeno conhecido como prótese, que se vê representado na escrita como no exemplo a seguir:

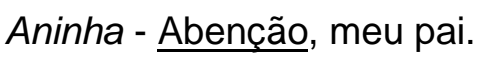

(Cena 4, linha 99 do Anexo, p. 201)

Aninha - Abenção, meu pai.

(Cena 7, linha 202 do Anexo, p. 206)

Este mesmo fenômeno acontece com a palavra "arrenegar", utilizada no texto com o sentido de "renegar" na fala de José da Silva na interação com o Juiz na cena 11:

José da Silva, com humildade - Vossa Senhoria não se arrenegue! Eu entregarei o pequira.

(Cena 11, linhas 371- 372 do Anexo, p. 216)

Outro exemplo de metaplasmo por acréscimo se dá com a palavra "rouxa" por "roxa", fenômeno conhecido como ditongação, na cena 11, em uma fala de Josefa Joaquina, roceira:

Josefa Joaquina - Bruxa é a marafona de tua mulher, malcriado! Já não se lembra que me deu uma embigada, e que me deixou uma marca rouxa na barriga? Se o senhor quer ver, eu posso mostrar. 
(Cena 11, linhas 260-262 do Anexo, p. 211)

A ditongação está presente também nas falas do Juiz de Paz. Temos o uso de "caicho" em vez de "cacho", "feichada" em vez de "fechada", "feicha" em vez de "fecha":

Juiz - Vamo-nos preparando para dar audiência hoje. (Arranja a mesa) O escrivão já tarda; sem dúvida está na venda do Manuel do Coqueiro ... [...]. ( Batem na porta.) Quem é? Pode entrar. (Entra um negro com um caicho de bananas e uma carta, que entrega ao Juiz.Juiz, lendo a carta: ) "III. " ${ }^{\mathrm{mo}} \mathrm{Sr}$. - Muito me alegro de dizer a V.S". que a minha ao fazer desta é boa, e que a mesma desejo para V.Sa . pelos circunlóquios com que the venero". (Deixando de ler: ) Circunlóquios ... Que nome em breve! O que quererá ele dizer? Continuemos. (Lendo:) "Tomo a liberdade de mandar a V.S . um caicho de bananas maçãs para V.S . comer com a sua boca e dar também a comer à Sr.Juíza e aos Srs.Juizinhos. [...]

(Cena 9, linhas 217-227 do Anexo, p. 208)

Juiz - Pois bem, retirem-se; estão conciliados. (Saem os dois.) Não há mais ninguém? Bom, está feichada a sessão. Hoje cansaram-me!

(Cena 11, linhas 373- 374 do Anexo, p. 216)

Manuel João - Amigo, venha cá. (Chega à porta do quarto e diz:) Você ficará aqui até amenhã. Lá dentro há uma cama; faça o favor de entrar. (Entra, e M.João feicha a porta.)

(Cena 17, linhas 436-438 do Anexo, p.222)

Na cena 21, o Juiz ora usa a ditongação, ora não. São os casos das palavras "despachar" e "despacho":

Juiz - Vou, sim. Quero-me aconselhar com um letrado para saber como hei-de despachar alguns requerimentos que cá tenho.

Escrivão - Pois Vossa Senhoria não os sabe despaichar?

Juiz - Eu? Ora essa é boa! Eu entendo cá disso? Ainda quando é algum caso de embigada, passa; mas casos sérios, é outra coisa. Eu lhe conto o que me ia acontecendo um dia. Um meu amigo me aconselhou que, todas as vezes que eu não soubesse dar um despaicho, que botasse o seguinte: "Não tem lugar." Um dia apresentaram-me um requerimento de um sujeito, queixando-se que sua mulher não queria viver com ele, etc. Eu, não sabendo que despacho dar, dei o seguinte: "Não tem lugar." [...]

(Cena 21, linhas 514-520 do Anexo, p. 227) 
Outra variante fonológica encontrada no texto e dicionarizada é a palavra "embigada" para a palavra "umbigada" por metafonia. O Houaiss, por exemplo, registra o uso como informal e tem o mesmo sentido de "umbigada". No texto, o termo consta em um requerimento escrito por um roceiro e lido pelo Escrivão na cena 11 e também está presente nas falas do Juiz de Paz, de Gregório e de Josefa Joaquina, ambos roceiros:

Escrivão, lendo - Diz Inácio José, natural desta freguesia e casado com Josefa Joaquina, sua mulher na face da Igreja, que precisa que Vossa Senhoria mande a Gregório degradado para fora da terra, pois teve o atrevimento de dar uma embigada em sua mulher, na encruzilhada do Pau-Grande, que quase a fez abortar, da qual embigada fez cair a dita sua mulher de pernas para o ar. Portanto pede a Vossa Senhoria mande o dito sujeito degradado para Angola. E.R.M.

Juiz - É verdade, Sr.Gregório, que o senhor deu uma embigada na senhora?

Gregório - É mentira, Sr.Juiz da paz, eu não dou embigadas em bruxas.

Josefa Joaquina - Bruxa é a marafona de tua mulher, malcriado! Já não se lembra que me deu uma embigada, e que me deixou uma marca rouxa na barriga? Se o senhor quer ver, eu posso mostrar.

Juiz - Não precisa mostrar, eu o creio.

Josefa Joaquina - Sr. juiz, não é a primeira embigada que este homem me dá; eu é que não tenho querido contar a meu marido.

Juiz - Está bom , senhora, sossegue. Sr.Inácio José, deixe-se destas asneiras, dar embigadas não é crime classificado no Código. Sr.Gregório, fará o favor de não dar mais embigadas na senhora; quando não arrumo-lhe com as leis às costas e meto-o na cadeia.Queiram-se retirar.

(Cena 11, linhas 252-269 do Anexo, p. 211)

Há, ainda, vários casos de alterações fonéticas. O texto apresenta um caso curioso de nasalização na fala do Escrivão na cena 15:

Escrivão - Parecem uns peruns.

(Cena 15, linha 410 do Anexo, p. 220)

A palavra "peru" que não possui som nasal acaba sofrendo uma assimilação das palavras anteriores que são nasalizadas: "parecem" e "uns". Além disso, também registramos um caso de despalatalização em uma fala do Juiz de Paz, "reio" em vez de "relho": 
José da Fonseca - Eu não me escandalizo; Vossa Senhoria tinha de algum modo razão, porém eu me emendarei.

Manuel João - E se não se emendar, tenho um reio.

(Cena 22, linhas 558- 560 do Anexo, p. 230)

$\mathrm{Na}$ última cena, a peça termina com uma canção em que se verificam algumas apócopes, frequentes ainda hoje na língua portuguesa do Brasil, com os verbos "comer" e "beber", "comê" e "bebê", representados graficamente no texto:

Todos - Se me dás que comê,

Se me dás que bebê,

Se me pagas as casas,

Vou morar com você. (Dançam.)

Juiz - Assim , meu povo! Esquenta, esquenta! ...

Manuel João - Aferventa! ...

Tocador, cantando - Em cima daquele morro

Há um pé de ananás;

Não há homem neste mundo

Como o nosso juiz de paz.

Todos- Se me dás que comê,

Se me dás que bebê,

Se me pagas as casas,

Vou morar com você.

(Cena Última, linhas 590-603 do Anexo, p. 232)

De acordo com os exemplos dados, é importante observar que as variantes fonológicas não caracterizam a classe social das personagens, visto que todas as personagens apresentam algum tipo de variante em termos de alteração fonética. Caracterizam o ambiente e a época em que as personagens estão inseridas. 


\section{CONSIDERAÇÕES FINAIS}

Nesta dissertação, propusemo-nos a analisar a construção das personagenstipo na comédia O Juiz de Paz da roça, de Martins Pena, precursor das comédias de costumes no contexto sócio-histórico do Brasil do século XIX. O escritor representou a língua do povo, época em que ela começa a aparecer na literatura. A peça de teatro, texto marcado pelo diálogo, aproxima-se da fala real, por mimetizar as principais características de uma conversação, e revela um retrato dos valores e costumes da época.

Primeiramente, efetuou-se um estudo da vida e obra do autor. Buscou-se ressaltar o contexto sócio-histórico do Brasil e a situação do teatro no país em termos de cultura na época.

Postulamos que o texto de teatro aproxima-se da língua falada nas conversações rotineiras, porém a língua falada é representada na escrita e, embora o escritor utilize recursos gráficos para indicar pausas, entonações e aspectos vocais, o texto de teatro é apreendido, em sua totalidade, quando é oralizado no palco. Devido a essas principais diferenças, encontramos a necessidade de estudar as características do texto teatral, estudo realizado no capítulo 2, o texto tanto escrito quanto oralizado. Acreditávamos encontrar nas comédias de Martins Pena as personagens-tipo e, por isso, decidimos dedicar uma seção para as principais características entre a comédia e o drama. Como escolhemos a caracterização das personagens dentro do contexto de uma peça teatral, acrescentamos um estudo das personagens no texto de ficção.

Para o estudo da comédia escolheu-se a peça escrita com as didascálias de encenação, devido à distância temporal e pouca divulgação da comédia de Martins Pena, com raras encenações. 
Os capítulos 3 e 4 foram destinados à apresentação das teorias que serviram de base para a análise. O capítulo 3 expôs a problemática da oralidade na escrita e as marcas de oralidade presentes no discurso literário. Por estudarmos o discurso, tornou-se conveniente uma seção para o estudo detalhado da enunciação no texto de teatro, caracterizado pela sua polifonia.

O capítulo 4 apresentou a relação entre linguagem e construção de um status ou papel social, englobando um breve estudo da importância das escolhas lexicais para a configuração de sentido no texto, um estudo das formas de tratamento, que revelam a organização de uma comunidade linguística em uma dada situação de fala e o levantamento de alguns aspectos fonéticos e fonológicos recorrentes no discurso oral. Tornou-se importante também uma seção dedicada à diversidade linguística, visto que vários fatores podem influenciar usos linguísticos em uma comunidade, inclusos aí as escolhas lexicais, as formas de tratamento e as alterações fonéticas. Para a relação entre o papel social do indivíduo e a escolha de alguns usos linguísticos para a construção de um status, percebeu-se a necessidade de tratar a teoria da preservação da face para o estudo da peça, principalmente, da figura do Juiz de Paz, personagem em que se evidencia a autoridade e a manipulação perante outras personagens ingênuas.

Martins Pena realizou um trabalho detalhado para caracterizar a personagem do Juiz, visto que foi por meio dela que o escritor faz a sua crítica social dos costumes brasileiros. Embora tenhamos realizado uma releitura da teoria da preservação da face, considerando a oposição entre atos verbais e não verbais "valorizantes" e "desvalorizantes" da imagem social, foi possível destacar a figura de contraste entre o real papel do Juiz na peça (um ignorante, tal como os roceiros da comédia) e a sua "máscara" (uma autoridade letrada de respeito). 
Partindo dos pressupostos teóricos apresentados, analisamos o corpus no capítulo 5, que se dividiu em várias seções para o estudo das escolhas lexicais, das escolhas tratamentais, dos aspectos fonológicos e dos elementos não verbais complementares ao estudo da peça, as didascálias. Procuramos examinar os elementos linguísticos que nos possibilitaram identificar as diferentes configurações das personagens. Verificamos, inicialmente, que as principais estratégias para construir um status ou um papel social estão relacionadas às escolhas lexicais e às escolhas tratamentais, complementadas com a ação, as atitudes das personagens, o ambiente e o vestuário.

Utilizando vocábulos típicos da língua oral, Martins Pena consegue caracterizar as suas personagens-tipo, estas que são inseridas em um contexto bem delineado pelo autor. As escolhas lexicais são ligadas em uma rede semântica que progride com o correr do texto. Elas caracterizam o local da roça e da corte, principalmente quando a personagem José da Fonseca faz descrições do ambiente da corte para Aninha de modo a contrastar com a roça. Além disso, as escolhas lexicais evidenciam a ingenuidade das personagens roceiras nos requerimentos escritos por elas e que são lidos pelo Escrivão para o Juiz de Paz. Não bastasse a caracterização do local e dos roceiros, as escolhas lexicais permitem dar uma "falsa" autoridade ao Juiz de Paz, visto que ele emprega termos jurídicos recorrentes em sua profissão, escolhas lexicais que o caracterizam nas interações com os roceiros. Embora o Juiz de Paz tenha uma profissão de respeito, ele não está habilitado para exercê-la, a imagem social de respeito do Juiz é desconstruída no decorrer da peça.

Além das escolhas lexicais, as formas de tratamento colaboram para a identificação dos tipos sociais e das classes sociais de cada personagem. 
As formas de tratamento que as personagens utilizaram em contextos diversos também se revelaram fundamentais para a caracterização dos papéis. Ressaltamos, a partir do exposto, que a situação comunicativa e a hierarquia social interferem na escolha das formas de tratamento, visto o modo como as mulheres empregam as formas de tratamento nas interações face a face com os respectivos companheiros. Para embasar nosso pensamento, citamos os estudos de Cintra (1986), Braun (apud Kerbrat-Orecchioni 1990) e Kerbrat-Orecchioni (1990) para a descrição e análise das situações.

O uso das formas de tratamento não se restringe ao significado que cada uma representa, os falantes atribuem diferentes valores a esses tratamentos para as mais diversas situações comunicativas, como "Sr. Juíza", "Sr.Juizinhos" em um requerimento de um roceiro para o Juiz de Paz. O uso de "Senhor" poderia destacar o respeito do roceiro em relação à família do Juiz de Paz e, no entanto, revela o desconhecimento desse tipo de uso linguístico e sua ingenuidade.

A escolha das formas de tratamento também expõe a aproximação entre locutor e interlocutor e a intimidade familiar em intercâmbios comunicativos de informalidade, caracterizados pela aproximação afetiva entre o locutor e o interlocutor, tais como "minha Aninha", "meu pai”, "minha mãe”. Em algumas situações, no entanto, escolhas tratamentais revelam a autoridade exercida no seio familiar ou no ambiente de trabalho.

As mulheres, na peça, mantêm uma relativa formalidade em relação aos homens, embora demonstrem afetividade e intimidade algumas vezes. Elas revelam um comportamento condizente com os estudos de Freyre (1998; 2000) e Biderman (1972/1973), visto que ambos defendem a mudança de tratamento durante o século XIX na relação mulher-homem (do uso de "senhor" para "tu" e "você"). 
As alterações fonéticas e fonológicas são importantes na análise do discurso oral, no entanto, não encontramos uma relação entre essas alterações e as personagens-tipo. Os aspectos fonéticos e fonológicos configuram mais o ambiente em geral e a época na peça.

Estudamos uma peça do século XIX porque acreditamos que a escrita é uma fonte da preservação linguística de uma sociedade e a pesquisa colaborará para estudos futuros relacionados à Análise da Conversação e à Sociolinguística Interacional. Acreditamos que este trabalho contribuiu para compreender a relação entre linguagem e sociedade, porque essa linguagem e sociedade são representadas pela literatura. Espera-se que os tópicos não contemplados nesta dissertação, devido ao escopo teórico, possam constituir e possibilitar outras investigações das relações entre as marcas de oralidade e a representação de uma sociedade e/ou de uma época. 


\section{REFERÊNCIAS}

ALENCAR, José de. Mãe. (1998) In: AGUIAR, Flávio (Org.). Antologia do teatro brasileiro: a aventura realista e o teatro musicado. São Paulo: SENAC.

ARÊAS, Vilma. (1987) Na tapera de Santa Cruz: uma leitura de Martins Pena. São Paulo: Martins Fontes.

ARMENGAUD, Françoise. (2006) A pragmática. São Paulo: Parábola Editorial. ASSIS, Machado de. (1994) Um erradio. Obra Completa, vol. II, Rio de Janeiro: Nova Aguilar.

ASSUMPÇÃO, Maria Elena Ortega Ortiz. (2010) Teatro x Narrativa: gêneros intercambiáveis?. Revista Linha D’Água. Edição Especial 30 anos, São Paulo: FFLCH/USP, p.59-70.

AULETE, Caldas; GEIGER, Paulo. (2012) Novíssimo Aulete - Dicionário contemporâneo da Língua Portuguesa. Rio de Janeiro: Lexikon Editorial.

BAKHTIN, Mikhail. (2009) Marxismo e filosofia da linguagem. São Paulo: Hucitec. [1929]

(2011) Estética da criação verbal. São Paulo: Martins Fontes.[1979]

BALLY, Charles. (1951) Traité de stylistique française, vol. I. Paris: Klincksieck.

BECHARA, Evanildo. (2009) Moderna gramática portuguesa. Rio de Janeiro: Lucerna/Nova Fronteira.

BENVENISTE, Émile (1966). Problèmes de linguistique générale I. Paris : Gallimard. (1988) Problemas de Linguística Geral I. Campinas, SP: Pontes: Editora da Universidade Estadual de Campinas.

(2006) Problemas de Linguística Geral II. Campinas, SP: Pontes. [1974]

BIDERMAN, Maria Tereza Camargo. (1972/1973) Formas de tratamento e estruturas sociais. ALFA. Volume 18/19, p. 339-382. 
(1996) Léxico e vocabulário fundamental. ALFA. Volume 40, São Paulo,

p.27-46.

BLANCHE-BENVENISTE, Claire. (2000) Approches de la langue parlée en français. Paris: Ophrys.

BORBA, Francisco da Silva. (2004) Dicionário UNESP do Português Contemporâneo. São Paulo: Editora UNESP.

BOSI, Alfredo. (1994) História concisa da literatura brasileira. São Paulo: Cultrix.

BRAIT, Beth. (2000). A personagem. São Paulo: Ática.

BROWN, Roger; GILMAN, Albert. (1960). The pronouns of Power and Solidarity. In: GIGLIOLI, Pier Paolo (Org.) (1990). Language and social context. London: Penguin. BROWN, Penélope; LEVINSON, Stephen C. (1987). Politeness: some universals in language use. Cambridge: Cambridge University Press.

CAFEZEIRO, Edwaldo; GADELHA, Carmem (1996). História do teatro brasileiro: um percurso de Anchieta a Nelson Rodrigues. Rio de Janeiro: Editora UFRJ/EDUERJ/FUNARTE.

CANDIDO, Antonio. (2004). O romantismo no Brasil. São Paulo: Humanitas.

CASTILHO, Ataliba Teixeira de (2010). Nova gramática do português brasileiro. São Paulo: Contexto.

CINTRA, Luís F. Lindley. (1986). Sobre "Formas de Tratamento" na Língua Portuguesa. Lisboa: Livros Horizonte. [1972] ; CUNHA, Celso Ferreira da. (2001). Nova gramática do português contemporâneo. Rio de Janeiro: Nova Fronteira.

COSTA, Amália. (Org.); PENA, Martins (1951). O Juiz de Paz da roça e O Judas no sábado de aleluia. Rio de Janeiro: Organização Simões. 
DAMASCENO, Darcy. (1956). Teatro de Martins Pena: comédias-dramas. Rio de Janeiro: Instituo Nacional do Livro. . (1971). Comédias de Martins Pena. Rio de Janeiro: Edições de Ouro.

FIORIN, José Luiz. (2006). Elementos de Análise do Discuso. São Paulo: Contexto. FLORES, Valdir do Nascimento et alii (2009). Dicionário de Linguística da Enunciação. São Paulo: Contexto.

FREYRE, Gilberto. (2008). Vida social no Brasil em meados do século XIX. São Paulo: Global. [1964] (2011). Casa - Grande e Senzala. São Paulo: Global. [1933]

GALEMBECK, Paulo de Tarso. (2008). Polidez e preservação da face na fala de universitários. In: PRETI, Dino. (Org.) Cortesia verbal. São Paulo: Humanitas, p.323353.

GENETTE, Gérard. (1972). Figures III. Paris: Seuil.

GOFFMAN, Erving. (1967). Interaction ritual: essays in face-to-face behavior. New Brunswick, N.J: Aldine Transaction. (2005). A representação do eu na vida cotidiana. Petrópolis: Vozes. [1959]

GUMPERZ, John Joseph. (1989). Engager la conversation: introduction à la sociolinguistique interactionnelle. Paris: Les Éditions de Minuit.

HELIODORA, Bárbara. (2000). Martins Pena, uma introdução. Rio de Janeiro: Academia Brasileira de Letras.

HILGERT, José Gastón. (2003). A seleção lexical na construção do texto falado. In: Léxico na língua oral e na escrita. São Paulo: Humanitas, p.69-102.

HOUAISS, Antônio; VILLAR, M.S. (2009). Dicionário Houaiss da língua portuguesa. Rio de Janeiro: Objetiva. 
INGARDEN, Roman. (1988.) As funções da linguagem no teatro. In: GUINSBURG, Jacó et alii (Org.) Semiologia do teatro. São Paulo: Perspectiva.

ISSACHAROFF, Michael. (1985). Le spectacle du discours. Paris: Corti, 1985.

KERBRAT-ORECCHIONI, Catherine. (1984). Pour une approche pragmatique du dialogue théâtral. Pratiques, Metz: CRESEF, n.41, p.46-62.

. (1990). Les interactions verbales, tome II. Paris: Armand Colin.

. (2006) Análise da conversação: princípios e métodos. São Paulo:

Parábola Editorial.

KOCH, Peter; OESTERREICHER, Wulf (1985). Sprache der Nähe-Sprache der

Distanz.Mündlichkeit und Schriftlichkeit im Spannungsfeld von Sprachtheorie und Sprachgeschichte.In: Romanistisches Jahrbuch, vol.36. Berlin/Nova lorque: Walter de Gruyter, p.15-43. Linguagem da imediatez - Linguagem da distância: Oralidade e Escrituralidade entre a teoria da linguagem e a história da língua.Trad. Raoni Caldas e Hudinilson Urbano. Linha D’Água: ensino de língua e literatura em debate. São Paulo: FFLCH/USP, vol.26, p. 153-174, 1ํ semestre 2013.

LEFEBVE, Maurice-Jean. (1975). Estrutura do discurso da poesia e da narrativa. Coimbra: Almedina.

LEITE, Marli Quadros. (2002). A norma linguística: perspectivas. In: Língua Portuguesa. PEC- Construindo Sempre - USP/CENP/SEE/SP, p.41-44.

LOPES, Célia Regina dos Santos; CAVALCANTE, Silvia Regina de Oliveira. (2011). A cronologia do voceamento no português brasileiro: expansão de você-sujeito e retenção do clítico-te. Revista Linguística da ALFAL, v. 25, p. 30-65.

MAINGUENEAU, Dominique. (1990). Éléments de linguistique pour le texte littéraire. Paris: Bordas. 
(2006). Termos-chave da Análise do Discurso. Belo Horizonte: Editora

UFMG.

MAGALDI, Sábato.(1997). Panorama do teatro brasileiro. São Paulo: Global.

MAGALHÃES JÚNIOR, Raimundo. (1971). Martins Pena e sua época. São Paulo: Lisa-Editora Irradiante.

MARCUSCHI, Luiz Antônio. (2004). Da fala para a escrita: atividades de retextualização. São Paulo: Cortez.

MARTINS, Nilce Sant'Anna. (1988). História da língua portuguesa. Volume V. São Paulo: Ática.

MATTOS e SILVA, Rosa Virgínia. (2011). Ensaios para uma sócio-história do português brasileiro. São Paulo: Parábola.

MOISÉS, Massaud. (2004). Dicionário de termos literários. São Paulo: Cultrix.

NASCENTES, Antenor. (1950). Fórmulas de tratamento no Brasil nos séculos XIX e XX. Revista Portuguesa de Filologia. Coimbra: Casa do Castelo, p. 52-68. . (1953). O linguajar carioca. Rio de Janeiro: Organização Simões.

OESTERREICHER, Wulf (1996). Lo hablado en lo escrito. Reflexiones metodológicas y aproximáción a uma tipologia.In: KOTSCHI, Thomas; Oesterreicher, Wulf y ZIMMERANN, Klaus (eds.). El español hablado y la cultura oral en Espana y Hispanoamérica.Madrid: Vervuert, p.317-340.

(1997). Pragmática del discurso oral. In: BERG, Walter Bruno; SCHÄFFAUER, Markus Klaus (eds.) Oralidad y Argentinidad - Estudios sobre la function del lenguaje hablado en la literatura argentina.Tubingen: Gunter Narrr Verlag, p.86-97.

PALLOTTINI, Renata (1989). Dramaturgia: a construção do personagem. São Paulo: Ática. 
PAVIS, Patrice. (2008). Dicionário de teatro. São Paulo: Perspectiva.

PENA, Luis Carlos Martins (1871). O Juiz de Paz da roça. Rio de Janeiro: Cruz Coutinho.

(s.d). Comédias. Rio de Janeiro: Garnier.

PRADO, Décio de Almeida (1999). História concisa do teatro brasileiro. São Paulo: Edusp.

(2009). A personagem no teatro. In: CANDIDO, Antonio. A personagem de ficção. São Paulo: Perspectiva, p.81-101.

PRETI, Dino. (1998). Oralidade e narração literária. Revista da ANPOLL São Paulo, Humanitas FFLCH-USP, v.4, 1998, p.81-96.

. (2002). A “conversação literária”. Revista da ANPOLL, v.12, p.89-109. . (2003a). Sociolinguística: os níveis de fala. São Paulo: Edusp. [1994] . (2003b). Variação lexical e prestígio social das palavras. In: Léxico na língua oral e na escrita. São Paulo: Humanitas, p.47-67. . (2004). Papéis sociais e formas de tratamento em $A$ ilustre casa de Ramires, de Eça de Queirós. In: Estudos de língua oral e escrita. Rio de Janeiro: Lucerna, p.180-199.

(2008). Linguagem, status e papéis sociais. In: CAVALIERE, Ricardo (Org.) Entrelaços entre textos. Rio de Janeiro: Nova Fronteira, p.271-279.

ROBINSON, William Peter. (1977). Linguagem e comportamento social. São Paulo: Cultrix. [1972]

ROMERO, Sílvio. (1943). História da literatura brasileira. Rio de Janeiro: José Olympio.

RUMEU, Márcia Cristina de Brito. (2012). Vestígios da pronominalização de Vossa Mercê > Você em missivas cariocas e mineiras: uma incursão pelo português 
brasileiro escrito nos séculos XIX e XX. Revista Veredas On-Line, Juiz de Fora, v.16, n.2, p. 36-55.

RYNGAERT, Jean-Pierre. (1996). Introdução à análise do teatro. São Paulo: Martins Fontes.

SILVA, Luiz Antônio da. (2003). Tratamentos familiares e referenciação dos papéis sociais. In: PRETI, Dino (Org.) Léxico na língua oral e na escrita. São Paulo: Humanitas, p.169-194.

SILVA NETO, Serafim da. (1977). Introdução ao estudo da língua portuguesa no Brasil. Rio de Janeiro: Presença.

UBERSFELD, Anne. (1977). Le lieu du discours. Pratiques. Metz: CRESEF, n.15/16, p-10-19.

URBANO, Hudinilson. (2000). Oralidade na literatura (O caso Rubem Fonseca). São Paulo: Cortez.

. (2008). O diálogo teatral na perspectiva da Análise da Conversação. In: PRETI, Dino (Org.). Diálogos na fala e na escrita, vol.7. São Paulo: Humanitas, p.195-223.

. (2011a). A frase na boca do povo. São Paulo: Contexto.

. (2011b). Variantes linguísticas. In: PRETI, Dino (Org.) Variações na fala e na escrita. São Paulo: Humanitas, p. 157-186. 


\section{Anexo}

O Juiz de Paz da roça

$1^{\text {a }}$ comédia composta por Luís Carlos Martins Pena 
Comédia em 1 ato

1838

\section{Personagens}

Juiz de Paz

Escrivão do Juiz de Paz

Manuel João, lavrador, guarda nacional.

Maria Rosa, sua mulher [de Manuel João]

Aninha, sua filha. [de Manuel João]

José da Fonseca, amante de Aninha

Inácio José

José da Silva

Francisco Antônio

Gregório

Lavradores

Negros

Manuel André

Sampaio

Tomás

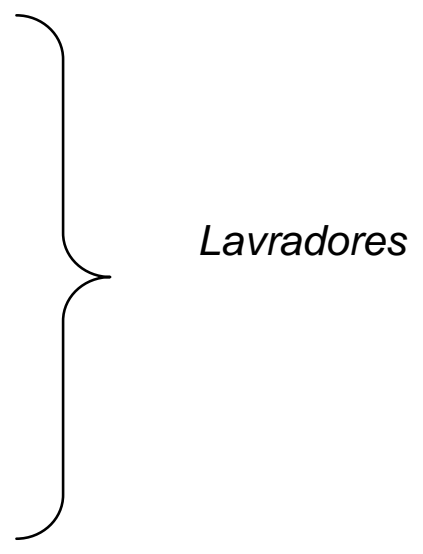

A cena é na roça 


\section{Cena 1}

1 Sala com uma porta no fundo. Alguns cestos estarão espalhados pela casa. No meio

2 da sala uma mesa, junto da qual estarão cosendo Maria Rosa e Aninha.

3

4 Maria Rosa - Teu pai hoje tarda muito.

5 Aninha-Ele disse que tinha muito que fazer.

6 Maria Rosa - Pobre homem! ... Ele mata-se em trabalhar!. É quase meio dia e ainda

7 não voltou para casa! Desde as quatro horas da manhã que ele saiu, está só com

8 uma chicra de café.

9 Aninha - Meu pai, quando principia um trabalho, não gosta de o deixar sem acabar,

10 e minha mãe bem sabe que ele tem só a Agostinho.

11 Maria Rosa - É verdade. Os meias-caras agora estão tão caros! Quando havia 12 valongo eram mais baratos.

13 Aninha - Meu pai me disse que havia comprar uma negrinha para mim quando 14 desmanchasse o mandiocal grande.

15 Maria Rosa - Ele já me disse tãobém isso.

16 (Silêncio)

17 Aninha - Minha mãe preparou a jacuba pra meu pai?

18 Maria Rosa - É verdade! Tinha-me esquecido. Vai aí fora no terreiro, e traz-me dois 19 limões.

20 (Aninha sai)

21 Maria Rosa - Se o Manuel João não achasse sua jacuba, tínhamos campanha velha.

22 Do que me tinha eu esquecido!

23 (Entra Aninha)

24 Aninha - Aqui estão os limões.

25 Maria Rosa - Fica tomando conta aqui na sala enquanto eu vou lá dentro.

26 (Vai-se).

27 Aninha - Minha mãe já ia tardando a sair daqui. Eu pensava que não poderia falar 28 hoje com o Sr.José da Fonseca. Ele está me esperando debaixo dos cafezeiros.

29 Mas, como minha mãe está ocupada lá dentro e meu pai não entra nesta meia hora, 30 eu posso fazê-lo entrar aqui. (Chega na porta e acena com o lenço). Ele aí vem. 


\section{Cena 2}

31 Entra José da Fonseca vestido de calças e jaqueta branca

33 José da Fonseca - Adeus, minha Aninha! (Quer abraçar Aninha).

34 Aninha - Fique quieto, Sr.José. Eu não gosto destes brinquedos, eu quero casar-me com o senhor, porém não quero que me abrace antes de casar-nos. José da Fonseca - Perdoa, minha Aninha.

37 Aninha - Esta gente quando vai à corte vem perdida. Ora, diga-me, concluiu a venda 38 do bananal que seu pai lhe deixou?

39 José da Fonseca - Concluí.

40 Aninha - O Sr. agora tem dinheiro, porque não me pede a meu pai?

41 José da Fonseca - Dinheiro! .... nem vintém.

42 Aninha - Nem vintém! ... Então o que fez do dinheiro? .... É assim que me ama? 43 (chora).

44 José da Fonseca - Minha Aninha, não chores! Olha, se tu soubesses como é bonita 45 a corte! ... Eu tenho um projeto que quero te dizer.

46 Aninha-Qual é?

47 José da Fonseca - Você sabe que eu agora estou pobre como Jó. Assim tenho 48 pensado em uma coisa ... Nós nos casaremos na freguesia sem que teu pai o saiba,

49 depois partiremos para o Rio de Janeiro para lá vivermos.

50 Aninha - Mas como, sem dinheiro?

51 José da Fonseca - Eu assentarei praça nos Permanentes.

52 Aninha - E minha mãe?

53 José da Fonseca - Ora tua mãe! Ela que fique rapando mandiocas, que é ofício 54 leve. Vamos para corte, que você verá o que é bom.

55 Aninha - O que há na corte de tão bom, que você não fala em outra coisa?

56 José da Fonseca - Eu te digo. Há dois teatros; em um deles pode caber vinte pés de 57 mangueira.

58 Aninha - Oh! Como é grande!

59 José da Fonseca - Representa-se quase todos os dias. Pois uma mágica que lá se 60 representou, oh! isto é coisa grande! 
61 Aninha - O que é mágica?

62 José da Fonseca - Mágica é uma peça que tem muito maquinismo.

63 Aninha-Maquinismo?

64 José da Fonseca - Sim, maquinismo. Eu te explico. Há um homem que de repente 65 vira-se macaco; paus tornam-se em cobras; um lenço queima-se nas mãos de um 66 deles sem que botem fogo; e outras coisas que fazem a gente ficar de boca aberta.

67 Aninha-Oh! Como deve ser bonito!

68 José da Fonseca - Muito bonito. Pois o curro dos cavalinhos?! Isto então é coisa 69 grande! No curro há uns cavalos muito bem ensinados, que dançam, fazem 70 mesuras, saltam, etc.; porém o que mais me espantou foi ver homens andarem em 71 pé em cima dos cavalos.

72 Aninha-Em pé!

73 José da Fonseca - Em pé e sem caírem! Eles fingem-se bêbados, jogam os socos, 74 fazem exercício em pé, em cima do cavalo e o cavalo sempre a correr à roda, sem 75 nunca caírem.

76 Aninha - Que vontade tinha eu de ver todas estas coisas!

77 José da Fonseca - Além disto há outras muitas coisas. Na rua do Ouvidor há um 78 cosmorama; na rua de S. Francisco de Paula, outro; e no Largo de S. Francisco há 79 uma casa aonde se vêem muitos bichos cheios, muitas conchas, cabrito com duas 80 cabeças e um jararacuçu vivo, que foi o que menos me admirou.

81 Aninha - Quando é que você pertende casar-se comigo, para podermos ir para 82 corte?

83 José da Fonseca - O vigário está pronto para qualquer hora.

84 Aninha - Então amenhã de menhã.

85 José da Fonseca - Pois sim. (Cantam dentro).

86 Aninha - Aí vem meu pai, vai-te embora antes que ele te veja.

87 José da Fonseca - Adeus, até amenhã de menhã.

88 Aninha-Adeus, não faltes.

89 (Vai-se) 


\section{Cena 3}

90 Aninha, só - Como é bonita a corte! Lá é que a gente pode se divertir e não aqui 91 aonde não se ouve senão os sapos e as entanhas cantarem! Teatros, mágicas, 92 cavalos que dançam, cabrito com duas cabeças, quanta coisa! Eu quero ir para 93 Corte. 


\section{Cena 4}

94 Entra Manuel João com uma enxada no ombro, vestido de calça de ganga azul, com 95 uma das pernas arregaçadas; japona de pano azul, e descalço. Acompanha-Ihe um 96 negro com um cesto na cabeça e uma enxada no ombro, vestido de camisa e 97 ceroulas de algodão.

98

99 Aninha - Abenção, meu pai.

100 Manuel João - Adeus, rapariga, aonde está tua mãe?

101 Aninha - Ela está lá dentro preparando a jacuba.

102 Manuel João - Diga a ela que traga, pois estou com muito calor.

103 (Aninha vai-se)

104 Manuel João - Olá, José, leva estas enxadas lá para dentro e vai botar este café no 105 sol.

106 (Vai-se o preto)

107 Manuel João, senta-se - Estou que não posso comigo; tenho trabalhado como um 108 burro. 


\section{Cena 5}

109 Entra M. Rosa, com uma tigela na mão, seguida de Aninha.

110

111 Manuel João - Adeus, Sra. Maria Rosa.

112 Maria Rosa - Adeus, meu amigo. Estás muito cansado?

113 Manuel João-Muito. Dá-me cá isto.

114 Maria Rosa - Pensando que você viria muito cansado, fiz a tigela cheia.

115 Manuel João - Obrigado (bebendo a jacuba). Hoje trabalhei como gente... Limpei o

116 mandiocal que estava muito sujo.... fiz uma derrubada do lado de Francisco Antônio

117 .... e abri uma vala para esgotar as águas que estavam fazendo o feijão apodrecer...

118 e hoje à tarde pertendo colher um pouco de café... Aninha?

119 Aninha - Meu pai.

120 Manuel João - Quando acabares de jantar, pega em um samburá, e vai colher o

121 café dos cafezeiros que estão à roda da casa.

122 Aninha - Sim senhor.

123 Manuel João - Senhora, o jantar está pronto?

124 Maria Rosa - Há muito tempo.

125 Manuel João - Pois traga.

126 Maria Rosa - Aninha, vai buscar o jantar de teu pai.

127 (Vai- se Aninha).

128 Manuel João - Senhora, sabe que mais? É preciso casarmos esta rapariga.

129 Maria Rosa - Eu já tinha pensado nisto; mas nós não somos ricos; e moça pobre

130 custa a achar casamento.

131 Manuel João - Sim senhora, mas uma pessoa já me deu a entender .... Falaremos

132 nisto com mais vagar.

133 (Entra Aninha com dois pratos e os deixa na mesa)

134 Aninha - Minha mãe, a carne seca se acabou.

135 Manuel João-Já?! ...

136 Maria Rosa - A última vez veio só meia arroba.

137 Manuel João - Carne boa não faz conta, voa. Assente-se, venha jantar. 
138 (Assentam-se todos e comem com as mãos. O jantar consta de carne seca, feijão e

139 laranjas.) Não há carne seca para o preto?

140 Aninha - Não senhor.

141 Manuel João - Pois que coma laranja com farinha, ele não é melhor do que eu.

142 Diabo! um dia destes eu ... Diabo de carne! ... hei-de fazer uma plantação ... Lá se

143 vão os dentes!... Deviam ter botado esta carne de molho no corgo ... Que diabo de

144 laranjas tão azedas! (Batem na porta) Quem é? (Logo que Manuel João ouve bater

145 na porta, esconde os pratos na gaveta e lambe os dedos.)

146 Escrivão do Juiz - Dá licença, Sr. Manuel João?

147 (ladram alguns cães)

148 Manuel João (levantando-se) - Passa fora, Jibóia! Boca Negra, passa fora! Pode 149 entrar quem é.

150 Escrivão (entrando) - Deus esteja nesta casa.

151 Manuel João - Amém.

152 Escrivão - Um criado da Senhora Dona e da Senhora Doninha.

153 Maria Rosa e Aninha - Uma sua criada (fazem uma mesura)

154 Manuel João - O Sr. por aqui a estas horas é novidade.

155 Escrivão - Venho da parte do senhor juiz de paz intimá-lo para levar um recuruta à 156 cidade.

157 Manuel João - Ó homem, não há mais ninguém que sirva para isto?

158 Escrivão - Todos se recusam do mesmo modo, e o serviço no entanto deve-se 159 fazer.

160 Manuel João-Sim, os pobres é que pagam.

161 Escrivão - Meu amigo, isto pouco patriotismo. Vós bem sabeis que é preciso 162 mandar gente para o Rio Grande; quando não podemos perder esta província.

163 Manuel João - Que me importa eu cá com isto? Que me importa com Rio Grande?

164 Quem as armou que as desarme.

165 Escrivão - Mas, meu amigo, os rebeldes têm feito por lá horrores, e é preciso que 166 sejam castigados.

167 Manuel João - E o que quer o senhor que se lhe faça? Ora essa é boa! Castigados 168 precisam ser aqueles que foram causa de tudo isto. Ora não é má esta! Um pobre 169 lavrador como eu ver-se obrigado a perder um dia de trabalho por causa do Rio 170 Grande, ao mesmo tempo que aqueles que foram causa estão de perninhas a 171 ganharem dinheiro. Não se dá maior patifaria! Ora esta! 
172 Escrivão, zangado - Tenha paciência, o senhor juiz manda-Ihe dizer que se não 173 comparecer, irá preso.

174 Manuel João - Diga lá ao senhor juiz de paz que lá irei.

175 Escrivão, à parte - Em boa o diga. (À parte) Custou-me achar um guarda.Apre! Às 176 vossas ordens.

177 Manuel João - Às vossas ordens.

178 Escrivão - Sentido nos vossos cães.

179 Manuel João - Eles não mordem.

180 Escrivão - Senhora Dona, passe bem.

181 Maria Rosa - Passe muito bem. (O Escrivão vá-se; ladram os cães.)

182 Manuel João - Passa fora! Mulher, arruma esta sala, enquanto me vou fardar. (Vai183 se.) 


\section{Cena 6}

184 Maria Rosa - Pobre homem! Ir à cidade só para levar um preso! Perder um dia de

185 trabalho ...

186 Aninha - Minha mãe, para que mandam a gente presa para cidade?

187 Maria Rosa - É para serem soldados e irem à guerra.

188 Aninha-Coitados!

189 Maria Rosa - Não se dá maior injustiça! Manuel João está todos os dias vestindo a

190 farda. Ora pra levar presos, ora pra dar nos quilombos ... É um nunca acabar.

191 Aninha - Mas meu pai pra que vai?

192 Maria Rosa - Porque o juiz de paz o obriga.

193 Aninha - Ora, ele podia ficar em casa; e se o juiz de paz cá viesse buscá-lo , não

194 tinha mais que iscar a Jibóia e a Boca-Negra.

195 Maria Rosa - És uma tolinha! E a cadeia ao depois?

196 Aninha - Ah, eu não sabia. 


\section{Cena 7}

197 Entra Manuel João com as mesmas calças e jaqueta de chita, tamancos, chapéu de 198 palha e um grande pau na mão.

199

200 Manuel João, entrando - Estou fardado. Adeus, senhora, até amenhã. (Dá um 201 abraço.)

202 Aninha - Abenção, meu pai.

203 Manuel João - Adeus, menina.

204 Aninha - Como meu pai vai à cidade, não se esqueça de trazer os sapatos 205 franceses que the pedi.

206 Manuel João - Sim, eu te trarei os sapatos. Adeus, minha gente.

207 Maria Rosa e Aninha - Adeus! (Acompanham-no até a porta.)

208 Manuel João, à porta - Não se esqueça de mexer a farinha e de dar que comer às 209 galinhas.

210 Maria Rosa - Não. Adeus! (Sai Manuel João.) 


\section{Cena 8}

211 Maria Rosa - Menina, ajuda-me a levar estes pratos para dentro. São horas de tu 212 ires colher o café e de eu ir mexer a farinha ... Vamos.

213 Aninha - Vamos, minha mãe. (Levam os pratos.) 


\section{Cena 9}

214 Casa do Juiz de paz. Haverá uma mesa com alguns papéis; cadeiras. Entra o Juiz

215 de paz vestido de calça branca, rodaque de riscado, chinelas verdes e sem gravata.

217 Juiz - Vamo-nos preparando para dar audiência hoje. (Arranja a mesa) O escrivão já

218 tarda; sem dúvida está na venda do Manuel do Coqueiro ... O último recuruta que

219 fizemos já me vai fazendo peso. Nada, não gosto de presos em casa. Podem fugir,

220 depois dizem que o juiz de paz recebeu algum presente. (Batem na porta.) Quem

221 é? Pode entrar. (Entra um negro com um caicho de bananas e uma carta, que 222 entrega ao Juiz. Juiz, lendo a carta:) "III. ${ }^{\text {mo }}$ Sr. - Muito me alegro de dizer a V.S”. que 223 a minha ao fazer desta é boa, e que a mesma desejo para V.Sa. pelos circunlóquios 224 com que lhe venero". (Deixando de ler:) Circunlóquios ... Que nome em breve! O 225 que quererá ele dizer? Continuemos. (Lendo:) "Tomo a liberdade de mandar a V.S”. 226 um caicho de bananas maçãs para V.S . comer com a sua boca e dar também a 227 comer à Sr.Juíza e aos Srs.Juizinhos.V.Sa . há-de reparar na insignificância do 228 presente; porém, II. ${ }^{\mathrm{mo}}$ Sr., as reformas da Constituição permitem a cada um fazer o que quiser, e mesmo fazer presentes; ora, mandando assim as ditas reformas, a

230 V.S‥ fará o favor de aceitar as ditas bananas, que diz minha Teresa Ova serem 231 muito boas.No mais, receba as ordens de quem é seu venerador e tem a honra de 232 ser- Manuel André de Sapiruruca." - Bom, tenho bananas para a sobremesa.Ó pai, 233 leva estas bananas para dentro e entrega à senhora.Toma lá um vintém para teu 234 tabaco.(Sai o negro.) O certo é que ser juiz de paz é bem bom. Nós temos de vez 235 em quando nossos presentinhos, ora de farinha, ora de galinhas e etc. (Batem na 236 porta.) Quem é?

237 Escrivão, dentro - Sou eu. 
238 Juiz - Ah, é o escrivão. Pode entrar. 


\section{Cena 10}

239 Escrivão - Eu já intimei ao Sr. Manuel João para levar o preso para cidade.

240 Juiz - Bom. Agora vamos-nos preparar a audiência. (Assentam-se ambos na mesa e

241 o juiz toca a campainha.) Os senhores que estão lá fora no terreiro podem entrar.

242 (Entram Inácio José e sua mulher, José da Silva, Francisco Antônio e Gregório,

243 todos vestidos como roceiros; uns de jaqueta de chita, chapéu de palha, calças

244 brancas de ganga, de tamancos, descalços; outros calçam os sapatos e meias

245 quando entram, etc. Tomás traz um leitão debaixo do braço.) Está aberta a

246 audiência. Os senhores que têm requerimentos para entregarem queiram-se

247 aproximar. 


\section{Cena 11}

Inácio José, Francisco Antônio, Manuel André e Sampaio entregam seus

249 requerimentos.

250

251 Juiz-Sr. Escrivão, faça o favor de ler.

252 Escrivão, lendo - Diz Inácio José, natural desta freguesia e casado com Josefa

253 Joaquina, sua mulher na face da Igreja, que precisa que Vossa Senhoria mande a

254 Gregório degradado para fora da terra, pois teve o atrevimento de dar uma 255 embigada em sua mulher, na encruzilhada do Pau-Grande, que quase a fez abortar, 256 da qual embigada fez cair a dita sua mulher de pernas para o ar. Portanto pede a

257 Vossa Senhoria mande o dito sujeito degradado para Angola. E.R.M.

258 Juiz - É verdade, Sr.Gregório, que o senhor deu uma embigada na senhora?

259 Gregório - É mentira, Sr. Juiz da paz, eu não dou embigadas em bruxas.

260 Josefa Joaquina - Bruxa é a marafona de tua mulher, malcriado! Já não se lembra 261 que me deu uma embigada, e que me deixou uma marca rouxa na barriga? Se o 262 senhor quer ver, eu posso mostrar.

263 Juiz - Não precisa mostrar, eu o creio.

264 Josefa Joaquina - Sr. juiz, não é a primeira embigada que este homem me dá; eu é 265 que não tenho querido contar a meu marido.

266 Juiz - Está bom, senhora, sossegue. Sr.Inácio José, deixe-se destas asneiras, dar 267 embigadas não é crime classificado no Código. Sr.Gregório, fará o favor de não dar 268 mais embigadas na senhora; quando não arrumo-lhe com as leis às costas e meto-o 269 na cadeia.Queiram-se retirar. 
270 Inácio José, para Gregório - Lá fora tu me pagarás.

271 Juiz - Estão conciliados. (Inácio José, Gregório e Josefa Joaquina saem.) Sr .

272 Escrivão, faça o favor de ler o outro requerimento.

273 Escrivão, lendo- "O abaixo-assinado vem dar os parabéns a V.S . por ter entrado

274 com saúde no novo ano financeiro. Eu, II. ${ }^{\text {mo }}$ Sr. Juiz da paz, sou senhor de um sítio

275 que está na beira do rio, aonde dá muito boas bananas e laranjas, e como vem a 276 encaixe, eu peço a V.S ${ }^{\mathrm{a}}$ o favor de aceitar um cestinho das ditas que mandarei hoje

277 à tarde. Mais, como ia eu dizendo, o dito sítio foi comprado com o dinheiro que 278 minha mulher ganhou nas costuras e noutras coisas mais; e, vai senão quando, um 279 meu vizinho, homem da raça do Judas, diz que metade do sítio Ihe pertence. E 280 então, que lhe parece , Sr.Juiz, não é desaforo? Mais, como ia dizendo, peço a V.Sa . 281 para vir assistir à marcação do sítio. Manuel André. E.R.M."

282 Juiz - Não posso deferir por estar muito atravancado com um roçado; portanto, 283 requeira ao suplente, que é o meu compadre Pantaleão.

284 Manuel André - Mais, Sr.Juiz, ele tãobém está ocupado com uma plantação.

285 Juiz - Você replica? Cadeia, cadeia!

286 Manuel André - Vossa Senhoria não pode prender-me à toa: a Constituição não 287 manda.

288 Juiz- A Constituição! ... Está bem! ... Eu, o Juiz de paz, hei por bem derrogar a 289 Constituição! Sr. Escrivão, tome termo que a Constituição está derrogada, e mande290 me prender este homem.

291 Manuel André - Isto é uma injustiça!

292 Juiz - Ainda fala? Suspendo-Ihe as garantias...

293 Manuel André- É desaforo... 
294 Juiz, levantando-se - Brejeiro! ... (Manuel André corre; o Juiz vai atrás.) Pega ...

295 Pega ... Lá se foi....Que leve o diabo. (Assenta-se.) Vamos às outras partes.

296 Escrivão, lendo - Diz João de Sampaio que, sendo ele "senhor absoluto de um leitão

297 que teve a porca mais velha da casa, aconteceu que o dito acima referido leitão

298 furasse a cerca do Sr.Tomás pela parte de trás, e com a sem - cerimônia que tem

299 todo o porco, fossasse a horta do mesmo senhor. Vou a respeito de dizer, Sr. Juiz,

300 que o leitão, carece agora advertir, não tem culpa, porque nunca vi um porco pensar

301 como um cão, que sempre é mais alguma coisa e pensa às vezes como o melhor

302 homem. Para V.Sa . não pensar que minto, Ihe conto uma história: a minha cadela

303 Tróia, aquela mesma que escapou de morder a V.Sํ. naquela noite, depois que the

304 dei uma tunda nunca mais comeu na cuia com os pequenos. Mas vou a respeito de

305 dizer que o Sr.Tomás não tem razão em querer ficar com o leitão só porque comeu

306 três ou quatro cabeças de nabo.Assim, peço a V.S ${ }^{a}$. que mande entregar-me o

307 leitão. E.R.M."

308 Juiz - É verdade, Sr.Tomás, o que o Sr.Sampaio diz?

309 Tomás - É verdade que o leitão era dele, porém agora é meu.

310 Sampaio - Mas se era meu, e o senhor nem mo comprou, nem lho dei, como pode

311 ser seu?

312 Tomás - É meu, sim senhor, e mais tenho dito.

313 Sampaio - Pois não é, não senhor. (Agarram ambos no leitão e puxam, cada um

314 para sua banda.)

315 Juiz, levantando-se - Senhores, larguem o pobre animal não o matem!

316 Tomás - Deixe-me, senhor!

317 Juiz - Sr. Escrivão, chame o meirinho. (Os dois apartando-se.) Espere, Sr. Escrivão,

318 não é preciso. (Assenta-se.) Meus senhores, só vejo um modo de conciliar esta 
319 contenda, que é darem os senhores este leitão de presente a algum amigo. Não

320 digo com isso que mo dêem.

321 Tomás - Lembra Vossa Senhoria bem. Peço licença a Vossa Senhoria para Ihe

322 oferecer.

323 Juiz - Muito obrigado. É o senhor um homem de bem, e que não gosta de 324 demandas. E que diz o Sr.Sampaio?

325 Sampaio - Vou a respeito de dizer que se Vossa Senhoria aceita, fico contente.

326 Juiz - Muito obrigado, muito obrigado! Faça o favor de deixar ver. Ó homem, está

327 gordo, tem toucinho de quatro dedos! Com efeito! Ora, Sr.Tomás, eu que gosto tanto 328 de porco com ervilha!

329 Tomás - Se Vossa Senhoria quer, posso mandar algumas.

330 Juiz - Faz-me muito favor. Tome o leitão e bote no chiqueiro quando passar. Sabe 331 aonde é?

332 Tomás, tomando o leitão - Sim senhor.

333 Juiz - Podem se retirar, estão conciliados.

334 Sampaio - Tenho ainda um requerimento que fazer.

335 Juiz - Então, qual é? Diga.

336 Sampaio - Desejava que Vossa Senhoria mandasse citar a Assembléia Provincial.

337 Juiz - Ó homem! Citar a Assembléia Provincial? E para quê?

338 Sampaio - Queria que V.S mandasse citar para que ela mandasse fazer cercado de 339 espinhos em todas as hortas.

340 Juiz - Isto é impossível, Sr.Sampaio! A Assembléia Provincial não pode ocupar-se 341 com coisas insignificantes.

342 Tomás - Insignificância, bem! Mas os votos que Vossa Senhoria pediu-me para 343 aqueles sujeitos não era insignificância. Então me prometeu mundos e fundos. 
344 Juiz - Está bom, veremos o que poderei fazer. Queiram-se retirar. Estão conciliados ;

345 tenho mais que fazer. (Saem os dois.) Sr. Escrivão, faça o favor de ... (Levanta-se

346 apressado e, chegando à porta, grita para fora:) Ó Sr.Tomás! Não se esqueça de

347 deixar o leitão no chiqueiro!

348 Tomás, ao longe - Sim senhor.

349 Juiz, assentando-se - Era muito capaz de se esquecer. Sr. Escrivão, leia o outro 350 requerimento.

351 Escrivão, lendo - Diz Francisco Antônio, natural de Portugal, porém brasileiro, que

352 tendo ele casado com Rosa de Jesus, trouxe esta por dote uma égua. "Ora, 353 acontecendo ter a égua de minha mulher um filho, o meu vizinho José da Silva diz 354 que é dele, só porque o dito filho da égua de minha mulher saiu malhado como o 355 seu cavalo. Ora, como os filhos pertencem às mães, e a prova disto é que minha 356 escrava Maria tem um filho que é meu, peço a V.S ${ }^{a}$. mande o dito meu vizinho 357 entregar-me o filho da égua que é de minha mulher."

358 Juiz - É verdade que o senhor tem o filho da égua preso?

359 José da Silva - É verdade; porém o filho me pertence, pois é meu, que é do cavalo.

360 Juiz - Terá a bondade de entregar o filho a seu dono, pois é aqui da mulher do 361 senhor.

362 José da Silva - Mas, Sr.Juiz....

363 Juiz - Nem mais nem meio mas ; entregue o filho, senão, cadeia.

364 José da Silva - Eu vou queixar-me ao Presidente.

365 Juiz - Pois vá, que eu tomarei apelação.

366 José da Silva - E eu embargo.

367 Juiz - Embargue ou não embargue, embargue com trezentos mil diabos, que eu não 368 concederei revista no auto do processo! 
369 José da Silva - Eu the mostrarei, deixe estar.

370 Juiz- Sr. Escrivão, não dê anistia a este rebelde, e mande-o agarrar para soldado.

371 José da Silva, com humildade - Vossa Senhoria não se arrenegue! Eu entregarei o

372 pequira.

373 Juiz - Pois bem, retirem-se; estão conciliados. (Saem os dois.) Não há mais

374 ninguém? Bom, está feichada a sessão. Hoje cansaram-me!

375 Manuel João, dentro - Dá licença?

376 Juiz - Quem é? Pode entrar.

377 Manuel João, entrando - Um criado da Vossa Senhoria.

378 Juiz - Oh, é o senhor? Queira ter a bondade de esperar um pouco, enquanto vou

379 buscar o preso (Abre uma porta do lado.) Queira sair para fora. 


\section{Cena 12}

382 Juiz - Aqui está o recuruta que deve levar para cidade. Deixe-o no quartel do

383 Campo de Santana e vá levar esta parte ao general. (Dá um papel.)

384 Manuel João - Sim, senhor. Mas, Sr. Juiz da paz, isto não podia ficar para amanhã?

385 Hoje já é tarde, pode anoitecer no caminho e o sujeitinho escapulir.

386 Juiz - Mas aonde há-de ele ficar? Bem sabe que não temos cadeias.

387 Manuel João - Isto é o diabo!

388 Juiz - Só se o senhor quiser levar para sua casa, tê-lo preso esta noite, ou em um 389 quarto, ou na casa da farinha; enfim aonde quiser.

390 Manuel João - Pois bem, eu o levarei.

391 Juiz - Sentido que ele não fuja.

392 Manuel João - Sim senhor. Rapaz, acompanha-me. (Saem Manuel João e José.) 


\section{Cena 13}

393 Juiz - Agora vamos nós jantar. (Quando se dispõem para sair, batem na porta.) Mais

394 um! Estas gentes pensam que um juiz é de ferro e que pode passar sem comer! 395 Pode entrar quem é! 


\section{Cena 14}

396 Entra Josefa Joaquina com três galinhas penduradas pelos pés em uma mão e uma

397 cuia de ovos na outra.

398

399 Juiz - Ordena alguma coisa?

400 Josefa Joaquina - Eu trazia este presente para o Sr. Juiz. Queira perdoar não ser

401 coisa capaz. Não trouxe mais porque a peste deu lá em casa, que só ficaram estas

402 que trago, e a carijó que lá ficou.

403 Juiz - Está bom; muito obrigado pela sua lembrança. Quer jantar?

404 Josefa Joaquina - Vossa Senhoria faça o seu gosto, que este é o meu que eu já fiz 405 em casa.

406 Juiz - Então, com sua licença.

407 Josefa Joaquina - Uma sua criada. (Sai.) 


\section{Cena 15}

408 Juiz, com as galinhas nas mãos - Ao menos com esta visita lucrei. Sr. Escrivão, veja 409 como estão gordas! Levam a mão abaixo. Então, que diz?

410 Escrivão - Parecem uns peruns.

411 Juiz - Vamos jantar. Traga estes ovos. 


\section{Cena 16}

412 Casa de Manuel João. Entram Maria Rosa e Aninha com um samborá na mão.

413

414 Maria Rosa - Estou que não posso comigo! Já mexi meio alqueire de farinha, e por

415 hoje basta.

416 Aninha - Minha mãe, aqui está o café que colhi.

417 Maria Rosa - Bota aí no chão, para amenhã ir pra o sol.

418 Aninha - Deus permita que meu pai não se esqueça de meus sapatos! A festa da

419 Conceição é pra semana, e se for, quero ir de sapatos novos.

420 Maria Rosa - Aonde estará aquele maldito negro? 


\section{Cena 17}

421 Entram Manuel João e José da Fonseca e as mesmas.

422

423 Manuel João - Deus esteja nesta casa.

424 Maria Rosa - Manuel João! ...

425 Aninha-Meu pai! ...

426 Manuel João, para José - Faça o favor de entrar.

427 Aninha, à parte - Meu Deus, é ele!

428 Maria Rosa - O que é isto? Não fostes para cidade?

429 Manuel João - Não, porque era tarde e não queria que este sujeito fugisse no 430 caminho.

431 Maria Rosa - Então quando vas?

432 Manuel João - Amenhã de madrugada. Este amigo dormirá trancado naquele quarto.

433 Aonde está a chave?

434 Maria Rosa - Na porta. (Enquanto os dois falam, Aninha e José da Fonseca falarão 435 por acenos.)

436 Manuel João - Amigo, venha cá. (Chega à porta do quarto e diz:) Você ficará aqui 437 até amenhã. Lá dentro há uma cama; faça o favor de entrar. (Entra, e M.João feicha 438 a porta.) Bom, está seguro. Senhora, vamos para dentro contarmos quantas dúzias 439 temos de bananas para levar amenhã pra cidade. A chave fica em cima da mesa; 440 lembrem-me, se me esquecer. (Saem Manuel João e Maria Rosa.) 


\section{Cena 18}

441 Aninha, só - Boa ocasião de dar escapula a ele... Mas como se deixou prender? ...

442 Ele me contará. Espiemos a ver se vem alguém... (Espia) Ninguém ... Vamos abrir.

443 (Pega na chave que está sobre à mesa e abre a porta.) Saia para fora. (Sai José da

444 Fonseca.)

445 José da Fonseca, entrando - Oh, minha Aninha, eu te devo!

446 Aninha - Deixemo-nos de comprimentos. Ora diga-me, como foi o senhor preso?

447 José da Fonseca - Assim que botei os pés fora desta porta, encontrei com o juiz de 448 paz, que me mandou prender para recuruta.

449 Aninha-Coitado!

450 José da Fonseca - E se teu pai não fosse incombido de me levar, estava perdido, 451 havia de sentar praça.

452 Aninha - Você podia dizer que não queria ser soldado.

453 José da Fonseca - Quem quisesse que não havia ser, pois eu sou solteiro, e não 454 tenho ofício nem benefício.

455 Aninha-Se nós fugíssemos agora para nos casarmos?

456 José da Fonseca - Lembras bem. O vigário a estas horas deve estar na igreja; assim 457 não tardemos.

458 Aninha-Pois vamos, antes que meu pai venha.

459 José da Fonseca - Vamos. (Saem correndo.) 


\section{Cena 19}

460 Maria Rosa, entrando - Ó Aninha! Aninha! Aonde está esta maldita? Aninha! Mas o

461 que é isto? Esta porta aberta? Ah! Sr. Manuel João! Sr. Manuel João!

462 Manuel João, dentro - O que é lá?

463 Maria Rosa - Venha cá depressa. (Entra Manuel João em mangas de camisa.)

464 Manuel João - Então, o que é?

465 Maria Rosa - O soldado fugiu!

466 Manuel João - O que dizes, mulher?!

467 Maria Rosa, apontando para a porta-Olhe!

468 Manuel João - Ó diabo! (Chega-se para o quarto.) É verdade, fugiu! Tanto melhor, 469 não terei o trabalho de levá-lo a cidade.

470 Maria Rosa - Mas ele não fugiu só ...

471 Manuel João - Hem?!

472 Maria Rosa - Aninha fugiu com ele.

473 Manuel João-Aninha?!

474 Maria Rosa - Sim.

475 Manuel João - Misericórdia! Minha filha fugir com um vadio daqueles! Eis, aí está o 476 que fazem as rusgas do Rio Grande. Se não fosse o Rio Grande, não haviam 477 recurutas e minha filha não fugiria com um deles.

478 Maria Rosa - Ingrata! Filha ingrata!

479 Manuel João - Dê-me lá minha jaqueta e meu chapéu, que quero ir à casa do juiz de

480 paz fazer queixa do que nos sucede. Hei-de mostrar àquele melquitrefe quem é 481 Manuel João ... Vá, senhora, não esteja a choromingar. 


\section{Cena 20}

482 Entram José e Aninha e ajoelham-se aos pés de Manuel João.

483

484 Ambos - Senhor!

485 Manuel João - O que é lá isso?

486 Aninha - Meu pai, aqui está o meu marido.

487 Manuel João - Teu marido?!

488 José da Fonseca - Sim senhor, seu marido. Há muito tempo que nos amamos, e 489 sabendo que vós não daríeis o vosso consentimento, fugimos e casamos na 490 freguesia.

491 Manuel João - E então? Agora peguem com um trapo quente. Está bom, levantam-

492 se; já agora não há remédio. (Aninha e José levantam-se. Aninha vai abraçar a 493 mãe.)

494 Aninha - E minha mãe, me perdoa?

495 Maria Rosa - E quando é que eu não hei-de perdoar-te? Não sou tua mãe? 496 (Abraçam-se.)

497 Manuel João - É preciso agora irmos dar parte ao juiz de paz que você já não pode 498 ser soldado, pois está casado.Senhora, vá buscar minha jaqueta. (Sai Maria Rosa.)

499 Então o senhor conta com o meu trabalho, não é assim?

500 José da Fonseca - Não senhor, eu tãobém tenho braços para ajudar; e se o senhor 501 não quer que eu aqui viva, irei para a Corte.

502 Manuel João - E que vai ser lá? 
503 José da Fonseca - Quando não possa ser outra coisa, serei ganhador da Guarda 504 Nacional. Cada ronda rende um mil-réis e cada guarda três mil -réis.

505 Manuel João - Ora, vá-se com os diabos, não seja tolo. (Entra Maria Rosa com a 506 jaqueta e chapéu, e de xale.)

507 Maria Rosa-Aqui está.

508 Manuel João, depois de vestir a jaqueta - Vamos pra casa do juiz.

509 Todos - Vamos. (Saem.) 


\section{Cena 21}

509 Casa do Juiz. Entra o Juiz de Paz e o Escrivão.

510

511 Juiz - Agora que estamos com a pança cheia, vamos trabalhar um pouco.

512 (Assentam-se à mesa.)

513 Escrivão - Vossa Senhoria vai amenhã à cidade?

514 Juiz - Vou, sim. Quero-me aconselhar com um letrado para saber como hei-de

515 despachar alguns requerimentos que cá tenho.

516 Escrivão - Pois Vossa Senhoria não os sabe despaichar?

517 Juiz - Eu? Ora essa é boa! Eu entendo cá disso? Ainda quando é algum caso de

518 embigada, passa; mas casos sérios, é outra coisa. Eu lhe conto o que me ia

519 acontecendo um dia. Um meu amigo me aconselhou que, todas as vezes que eu

520 não soubesse dar um despaicho, que botasse o seguinte: "Não tem lugar." Um dia

521 apresentaram-me um requerimento de um sujeito, queixando-se que sua mulher não

522 queria viver com ele, etc. Eu, não sabendo que despacho dar, dei o seguinte: "Não

523 tem lugar." Isto mesmo é que queria a sujeitinha; porém o marido fez uma bulha de

524 todos os diabos; foi à cidade, queixou-se ao Presidente, e quase que fui suspenso.

525 Nada, não quero que me aconteça outra.

526 Escrivão - Vossa Senhoria não se envergonha, sendo um juiz de paz?

527 Juiz - Envergonhar-se de quê? O senhor ainda está muito de cor. Aqui para nós,

528 que ninguém nos ouve, quantos juízes de direito há por estas comarcas que não 
529 sabem aonde têm sua mão direita, quanto mais juízes de paz ....E além disso, cada

530 um faz o que sabe. (Batem.) Quem é?

531 Manuel João, dentro - Um criado de Vossa Senhoria.

532 Juiz - Pode entrar. 


\section{Cena 22}

533 Entram Manuel João, Maria Rosa, Aninha e José.

534

535 Juiz, levantando-se - Então, o que é isto? Eu pensava que já estava longe daqui!

536 Manuel João - Não senhor, ainda não fui.

537 Juiz- Isto vejo eu.

538 Manuel João - Este rapaz não pode ser soldado.

539 Juiz- Oh, uma rebelião? Sr. Escrivão, mande convocar a Guarda Nacional e oficie ao

540 Governo.

541 Manuel João - Vossa Senhoria não se aflija, este homem está casado.

542 Juiz- Casado?!

543 Manuel João - Sim senhor, e com minha filha.

544 Juiz - Ah, então não é rebelião... Mas vossa filha casada com um bilitre destes?

545 Manuel João - Eu o tinha preso em meu quarto para levá-lo amenhã para a cidade;

546 porém a menina, que foi mais esperta, furtou-me a chave e fugiu com ele.

547 Juiz - É verdade isto, menina?

548 Aninha - Sim senhor, Sr. Juiz. Há muito tempo que o amo, e como achei ocasião, 549 aproveitei.

550 Juiz - A menina não perde ocasião! Agora, o que está feito está feito. O senhor não

551 irá mais para a cidade, pois está casado. Assim, não falemos mais nisso. Já que 552 estão aqui, hão-de fazer o favor de tomar uma xícara de café comigo, e dançarmos 553 antes disto uma tirana. Vou mandar chamar mais algumas pessoas para fazerem a

554 roda maior. (Chega à porta.) Ó Antônio! Vai à venda do Sr.Manuel do Coqueiro e 
555 dize aos senhores que há pouco saíram daqui que façam o favor de chegarem até 556 cá. (Para José:) O senhor queira perdoar se o chamei de bilitre; já aqui não está 557 quem falou.

558 José da Fonseca - Eu não me escandalizo; Vossa Senhoria tinha de algum modo 559 razão, porém eu me emendarei.

560 Manuel João - E se não se emendar, tenho um reio.

561 Juiz - Senhora Dona, queira perdoar se ainda a não cortejei. (Comprimenta.)

562 Maria Rosa, comprimentando - Uma criada de Sua Excelência.

563 Juiz-Obrigado, minha senhora... Aí chegam os amigos. 


\section{Cena Última}

564 Os mesmos e os que estiveram em cena.

565

566 Juiz - Sejam bem-vindos, meus senhores. (Comprimentam-se.) Eu os mandei

567 chamar para tomarem uma xícara de café comigo e dançarmos um fado em

568 obséquio ao Sr.Manuel João, que casou sua filha hoje.

569 Todos - Obrigado a Vossa Senhoria.

570 Inácio José, para Manuel João - Estimarei que sua filha seja feliz.

571 Os outros - Da mesma sorte.

572 Manuel João-Obrigado.

573 Juiz - Sr. Escrivão, faça o favor de ir buscar a viola. (Sai o Escrivão.) Não façam

574 ceremônia; suponham que estão em suas casas. Haja liberdade. Esta casa não é 575 agora do juiz de paz - é de João Rodrigues. Sr.Tomás, faz-me o favor? (Tomás

576 chega-se para o Juiz e este o leva para um canto.) O leitão ficou no chiqueiro?

577 Tomás - Ficou, sim senhor.

578 Juiz - Bom (Para os outros:) Vamos arranjar a roda. A noiva dançará comigo, e o

579 noivo com sua sogra. Ó Sr.Manuel João, arranje outra roda ... Vamos, vamos!

580 (Arranjam as rodas; o Escrivão entra com uma viola.) Os outros senhores 581 abanquem-se....Sr.Escrivão, ou toque, ou dê a viola a algum dos senhores.Um fado

582 bem rasgadinho ....bem choradinho ...

583 Manuel João - Agora sou eu gente!

584 Juiz - Bravo, minha gente! Toque, toque! (Um dos atores toca a tirana na viola; os 585 outros batem palmas e caquinhos, e os mais dançam.) 
586 Tocador, cantando - Ganinha, minha senhora

587 Da maior veneração;

588 Passarinho foi-se embora,

589 Me deixou penas na mão.

590 Todos - Se me dás que comê,

591 Se me dás que bebê,

592 Se me pagas as casas,

593 Vou morar com você. (Dançam.)

594 Juiz - Assim , meu povo! Esquenta, esquenta! ...

595 Manuel João-Aferventa! ...

596 Tocador, cantando - Em cima daquele morro

597 Há um pé de ananás;

598 Não há homem neste mundo

599 Como o nosso juiz de paz.

600 Todos- Se me dás que comê,

601 Se me dás que bebê,

602 Se me pagas as casas,

603 Vou morar com você.

604 Juiz - Aferventa, aferventa! ...

605 FIM. 
